1968

\title{
Quantitative Analysis of Beach Sand Movement, Virginia Beach, Virginia
}

John D. Boon

College of William and Mary - Virginia Institute of Marine Science

Follow this and additional works at: https://scholarworks.wm.edu/etd

Part of the Geomorphology Commons

\section{Recommended Citation}

Boon, John D., "Quantitative Analysis of Beach Sand Movement, Virginia Beach, Virginia" (1968).

Dissertations, Theses, and Masters Projects. Paper 1539617401.

https://dx.doi.org/doi:10.25773/v5-kpx0-q629

This Thesis is brought to you for free and open access by the Theses, Dissertations, \& Master Projects at W\&M ScholarWorks. It has been accepted for inclusion in Dissertations, Theses, and Masters Projects by an authorized administrator of W\&M ScholarWorks. For more information, please contact scholarworks@wm.edu. 


\title{
QUANTITATIVE ANALTSIS OF BRACH SAMD MOVKMENT, VIRGINIA BEACA, viretara
}

\author{
A Thesis \\ Presented to \\ The Faculty of the School of Marine Selence \\ The Collage of Willla and Mary in Virginla
}

In Partial Tulfiliment

of the Requirements for the Degree of

Mastar of Arts

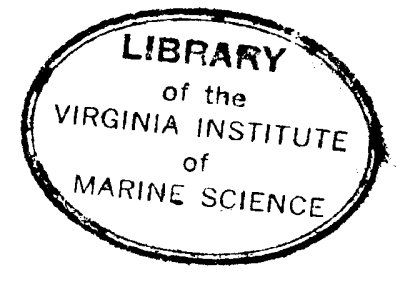

By

John D. Boon, III

1968 
ProQuest Number: 10625047

All rights reserved

INFORMATION TO ALL USERS

The quality of this reproduction is dependent upon the quality of the copy submitted.

In the unlikely event that the author did not send a complete manuscript and there are missing pages, these will be noted. Also, if material had to be removed, a note will indicate the deletion.

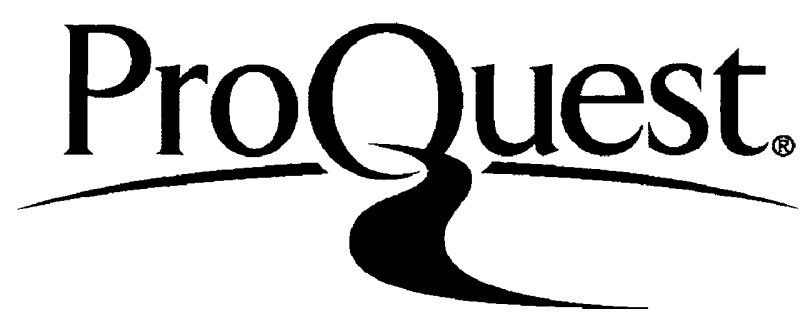

ProQuest 10625047

Published by ProQuest LLC (2017). Copyright of the Dissertation is held by the Author.

All rights reserved.

This work is protected against unauthorized copying under Title 17, United States Code Microform Edition $\odot$ ProQuest LLC.

ProQuest LLC.

789 East Eisenhower Parkway

P.O. Box 1346

Ann Arbor, MI 48106 - 1346 
APPROVAL SHEET

Th1s thesis is submitted in partial fulfillment of the requirements for the degree of

Master of Arts

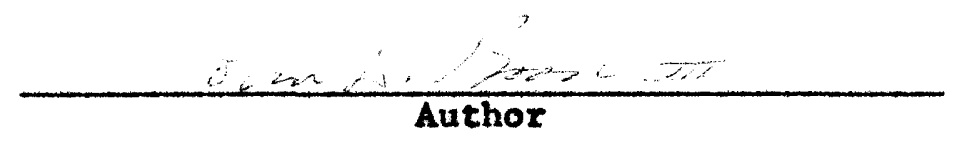

Approved, February, 1968

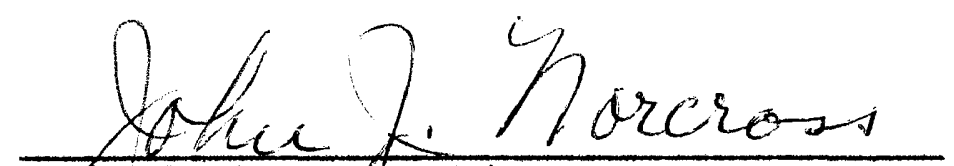

John J. Norcrogf, M.A.

O 11

Pliman Nawara

P. Wymp Harrison, Ph.D.

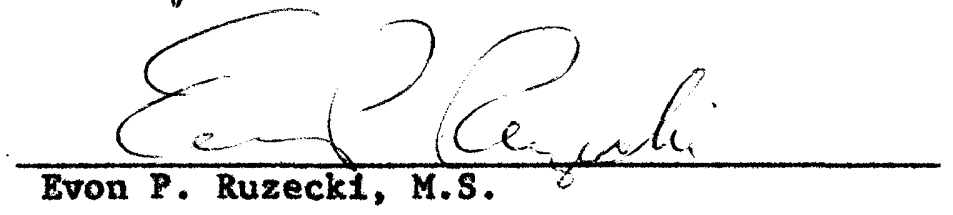


ACKNOWLEDGMENTS

The author is Indebted to Professor John J. Norcross and Dr. P. Wyman liarrison for much helpful guldance and constructive criticlsm during the course of the present study. Professor Norcross, of VIMS, provided numerous suggestlons and instructions regarding statistical applications and impressed upon the author the Importance of such applications in the natural sciences. Dr. Harrison, as Director of the Land and Sea Interaction Laboratory (LASIL) of the U. S. Environmental Sclence Services Adainistration, introduced the author to the technique of sand tracing and the systematic study of beaches, and also provided the necessary materials for the accomplishment of the fleld study. Dr. Robert Byrne, of LASIL, read portions of the prellminary manuscript and nade valuable suggestions which were Incorporated in the final text of the thesis.

Field operations were carried out in conjunction with a related LASIL study at Virginla Beach, VIrginla. The author was able to secure the services of, and is grateful to, members of the LASIl staff including Megsrs. E. Rayfleld, D. Tyler, B. Grant, and G. Reynolds. Finally, gratitude is expressed to nembers of Girl Scout Troop 266 (Trallblazers) of Virginia Beach, who also assiated in fleld operations.

Thanks and appreciation are given to the Corps of Commissioned Officers, U. S. Environmental Sclence Services Administration, especially to RADM Janes C. Tison, Jr. and RADM John C. Bull for permitting the author to purgue the research leading to the present thesis. 
TABLE OF CONTENTS

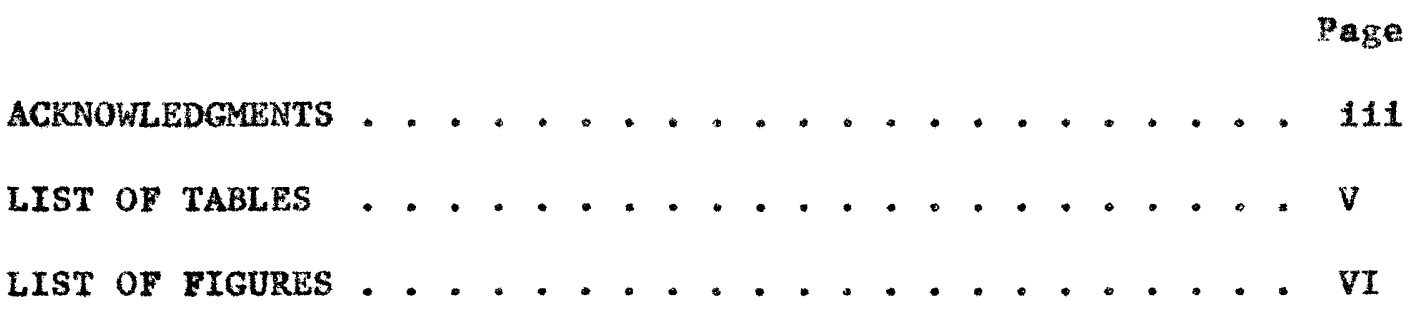

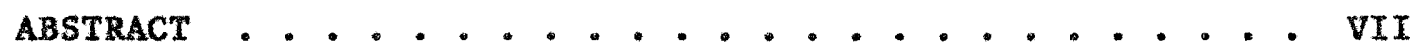

I. INTRODUCTION ..... . . . . . . . . . . . . . . . 2

II. PREVIOUS INVESTIGATIONS - . . . . . . . . . . . . . . . . 4

III. PRESENT STUDY - . - . . . . . - . . . . . . . . . . . . . . 8

Description of Area ...................... . 8

DesLgn of Experiment . . . . . . . . . . . . . . . . 9 Model Selection . . . . . . . . . . . . . . . 9

Stochast1c-Process Models . . . . . . . . . . . . 11

Tracer Partlcle Dlsplacement Nodel . . . . . . . . 13

Execution of Experiment . . . . . . . . . . . . . 14

Preparation of Tracers . . . . . . . . . . . . . . . 14

Injection of Tracers and Sampling Technique . . . . 16

Measurement of Environmental Factors . . . . . . . 18

Laboratory Work . . . . . . . . . . . . . . . 21

Method of Counting Fluorescent Grains . . . . . . 21

Method of Rap1d Sand Analysis . . . . . . . . . 22

Method of Computing Foreshore Erosion-Deposition . . 24

Data Anelysis . . . . . . . . . . . . . . . 25

Distributlon of Tracers . . . . . . . . . . 25

Fourter Trend Surface Analys1 . . . . . . . . . 25

Blvarlate Data Analysis . . . . . . . . . . . . 30

Comparison of Group Means . . . . . . . . . . . 33

Time-Stratification of Mean Displacement . . . . . . 34

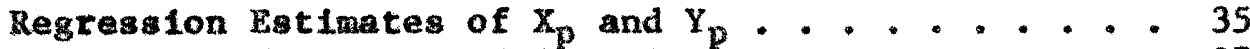

Estimates of Mean Particle Velocities........ 37

Discussion of Results . . . . . . . . . . . . 38

Comparison of Particle Movement and Environmental

Factors .................... 38

Comparison of Mean Particle Velocity with Expected

Particle veloctty . . . . . . . . . . . . 41

Estination of Mean Rate of Sand Transport . . . . 45

Recomendations for Future studies . . . . . . . 47 


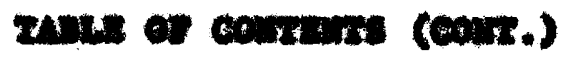

nare

1. comand.............................. so

1. Menot: ............................. 32

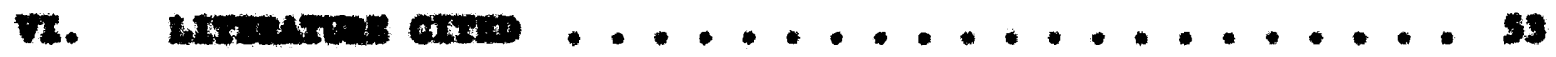

ns. na ................................ 5 


\section{LIST OF TABLES}

\section{Table}

1. List of anvironmental factors measured near Pandelton Transect, Septenber 16, $2200 \mathrm{hres}$. (tw), and September 17, $1100 \mathrm{hre.}$. (HW), 1966

2. Tracer concentration data

3. Sumary of ch1-कquare teste, zones versus $\mathrm{X}$ dieplacenents

4. Computer output of program MAT

5. Pendelton tracer data, X displacuents; " $t$ " teats of $\mathrm{B}_{0}: \mu_{1}=\mu_{2}$ for four pafrs of group detan per dynante zone

6. Pendelton tracer data, $廿$ diaplacenents: " $t$ " teat of $H_{0}: \mu,-\mu_{2}$ for four pairs of group mean data per dyoanlc zoke 
LISI OF FIGUELS

PIgure

1. Locacton map for area of sudy (after Warrison, et al., 1965)

2. Charactertatice of beaches (after Ing1e, 1966).

A: Ceneral feature and terminology.

D: Desigration of dynamic zonew and idealized

water-eireulatory patterna.

3. Map showing botton copography and posiclon of surf and swath zones, Fendelton Transect, Sept. 17, 1100 Mrg. (datum: Hrbitrary).

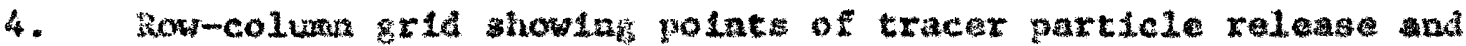
sand sasaple rocovery.

5. Device used to obtain sand cores at Pendelton Transect.

6. Mear setting velocttied, $\bar{U}_{3}$ of sand samples. A: $\bar{U}_{\text {g ploted }}$ arafnat distance long colukn CD for sept. 16, 2200 hrs, Sept. 17, $1100 \mathrm{hrs}$." and for tracer material (U. $4.15 \mathrm{cen} / \mathrm{sec})$ B: hap of field distribution of $\widetilde{\mathrm{U}}_{\mathrm{s}}$. Sept. 17, $100 \mathrm{hrs}$.

7. Schematlc section of besch howing method of detarmintag af for two succestive high thes, Segt. 16, $2200 \mathrm{hra} .$, and sept. 17. $1100 \mathrm{hrs}$. (wodifled from Larrison, et al., 1968). (A) is the powten of top of awsh on successive hikit water stands, and

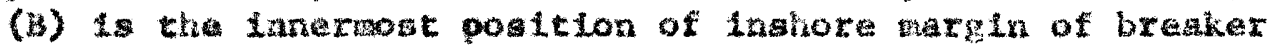
zone on wccesgtve high watar grands.

a. Tourter cxend continuous aysabol mas of tracer particle concentration 10 atn. after relase (contours added by the athor).

9. Pourier trend contlanoub symol map of tracer particle concentration $20 \mathrm{~min}$. after release (contour added by the author).

10. Fouriar trend conclnuou symbol ap of tracer particlo coucentration $30 \mathrm{~min}$. afcer release (contours added by the author).

11. Pourfer trand continuous symbol map of tracer particle concentration 40 in. after release (contoura added by the author).

12. Pourter trend contlauous syobol nap of tracar particle concentration $50 \mathrm{ndn}$. after release (contours added by the author). 


\section{LIST OY FICURES (CONT.)}

\section{Figure}

13. Schmatic diagran showing derivetion of bivariate displacemento data for $\mathrm{N}$ recovered tracer particlee.

14. Frequency-displacenent digrams for the swash zone lacluding fitted normal curves, sept. 17, 1100 hrs.

15. Frequency-diaplacenent d1agram for the surf zone Including fitted norwal curves, Sept. 17, $1100 \mathrm{hr}$.

16. Time-displacement diagrans showing group means with approximate confidence Intervals, sept. 17,1100 hre.

17. Sehosiatle dlagram showlng the relationship betwen the posttion of tracer particles, $x_{0}$, upon 1ujection and the "Impulse" displaceaent, $x_{p}$, away from the injection polnt immedlately following relense. The same relationshe holds for the direction.

18. Schematic representation of tracer particle dilution wh tine in a sand watrlx and subsequent "Loss" of tracer at depth.

19. Tite-frequency raph for tracer particles recovared by Yasso (1.65) at Sandy Hook, New Jersey. 


\section{ABSTRACT}

The present study describes a new approach to quantitative sediment tracing with dyed (fluorescent) particles, which can be used to obtain estimates of grain velocity, estimates of mobile layer thickness, and estlmates of the rate of longshore sand transport.

A simplifled stochast1c-process model was employed Involving the use of statistical procedures to analyze tracer displacement data on a time-stratifled basis. The procedures provide neaningful estimates of the direction and raguitude of the movement of beach sand through set intervals of time.

Results of a single tracer experiment are reported from a beach located near Virginia Beach, Virginia. The tracer particle-displacement data obtained were: 1) subjected to preliminary tests to determine the need to separate the data according to two dynamic zones; 2) treated as normally distributed populations in which mean particle displacements were computed for specific times following tracer release and compared with one another using " $t$ " tests to determine slgniflcant mean differences; 3) time-stratified where successfully tested so that weighted mean displacements representing the time interval 0 to 50 minutes could be computed; and 4) converted to raean particle velocities by dividing adjusted mean displacements by average travel time. For the morning of September 17, 1966, during moderate wave conditions at high tide, average particle velocity was determined for the swash and surf zones. In the swash zone, $\bar{V}(\mathrm{X})=0.44 \mathrm{ft} . / \mathrm{min} .(0.22 \mathrm{~cm} . / \mathrm{sec}$.$) in the longshore$ direction. In the surf zone, $\bar{V}(Y)=0.37 \mathrm{ft} . / \mathrm{min} .(0.19 \mathrm{~cm} . / \mathrm{sec}$.$) in$ the offshore direction.

Computed mean erain velocities and certain environmental data gathered priox to the time of the tracer experinent were used to rake an estimate of the thickness of the moblle layer (the depth interval In which semi-continuous motion of the grains occurs). The thickness, based on grain veloctty in the offshore direction and the raeasured rate of sand accretton seaward, was about $0.5 \mathrm{ln}$. $(1.3 \mathrm{~cm}$.$) ; assuring this$ to be the thickness of the mobile layer in the swash zone as well, an estinate of the longshore rate of sand transport was then computed using known values of swash zone width and longshore grain velocity. A transport value of $440 \mathrm{yd} .{ }^{3} /$ day (336 $\left.\mathrm{m} .{ }^{3} / \mathrm{day}\right)$, in a longshore direction was obtained. 


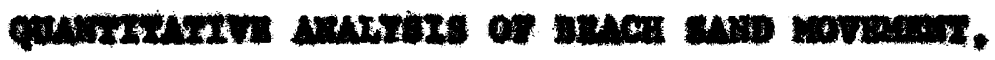

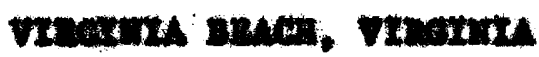




\section{INTRODWCTION}

This study axanines the woventent of and particles on an ocean beach. It Includeo method for esthaclng average rates of beach sand toverant in the litcoral zone. The method utilized lavolves the use of and tracers conslating of quartz arains coated with fluorescent dye. Tracers released in araas of sand trangport can reveal the difrecton of this tranpport, and the avarage velocley of the Individual graing estimated through a statistical procedure applied to the tracer recovary data.

A substantial anount of sand 18 transpotted daily along iast baschea undar the influence of wave-Induced longehore currenta. A large atora can effect highly algnificant changes in the profiles of beaches and at auch tiags it is evident to the most casual observer that large volutaes of and have been moved into or out of a given area. Indeed, measurament of the areas enclosed by the-sequontial profiles has beea the standard aeans by whlch coastal englnear attate the net "cut" or "\$111" per unlt tine at aelacted locationa (e.2., Caldwe11, 1956; Johnson, 1956). This involves mutiplying the area anclosed between two successive proflles by anit distance along the beach (usually one meter), whereupon the net voluae change 1 found for this section of the beach. However, while the net volume change way occastonally be near zero (an equilibrium beach), the grose transfer of materfal over a gtven period of that could be considerable, meaning that a steady transport of sand exists at souse 
point but no net erosion or doposteton occura there. In auch ases, sand traps or the accumulation of matexial agalnot natural barrier usually

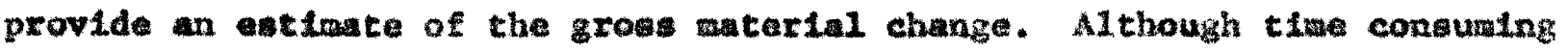
and expensive to acquire, the quantitativo information gatned has ita value in the design of edequate protective measures in areas undergolng exceselve sand accualiation or exosion. For example, devere seasonal arosion In the forashore zone may be offet by intermittent dredging or pumping of sand frow other areas to the area of concern. The cost of such operations requitas some previous knowledge of the quantities of sand being exchanged at wartous thes if the thethod is to ba affelent. 


\section{PREVIOUS INVESTIGATIONS}

At present, the volume of sand transported across a eection of beach in a given time is being calculated in more direct ways than by simple comparisons of profile data. Recent investigators have been more concerned with the dynarics of the beach-ocean-atmosphere system, and have begun to examine the movement of Individual sand particles In devialng ways of estinating the average sand transport along a beach. Russel1 (1960) first used tracers to obtain a quantitative estimate of littoral drift. He released quantities of dyed pebbles at a single point, at one week intervals, to establish semi-continuous source of tracer material. He assumed tracers would seek a certain level on the foreshore and move with simllarly sized pebbles in response to hydrodynamic forces, and visualized a two-way system of transport with the zone of travel divided into Inagtnary compartments. Further, the dimensions of the inftial compartment were chosen so that if it contained Pounds of material, pM pounds would go to the left and gil pounds would go to the right, where $p+q=1$ over a time interval of one week. After rany Injections, mathematically derlved tracer distributions for geveral combinations of $p$ and $q$ values were compared with the actual fleld distribution, as determined from unit area surface counts of dyed pebbles, so that estimates of $p$ and $q$ were obtained. The net rate of transport was then $(p-q) M / t$, where $M / t$ in pounds per week was also found wathematically from a knowledge of the tracer distribution. Using this technique, Russell. calculated the net transport along a shingle beach at Rye, England to be 
31,000 tons per year as compared to 53,000 tons per year for this beach according to avallable profile daca. As caution, he also mentioned the fallure of his method to account for any offshore-onshore tracer movement, and did not recomand $1=s$ use on sandy beaches where such woventent often occurs.

Ingle (1966) presented data on the average grain velocity of beach sand in a comprehensive monograph on the use of fluorescent sand tracexs. Whereas Russell exployed essentially a lino of auplins polnts. Ingle obtalned date from sampling grid by collecting sand wth greasecoated cards along several transects perpendicular to the shoreline. His areal data were used to construct equal-value contours, or 1sopleths, of tracer gratn concentration (dyed gralus per unte area) in plane approximating the sediment-watex interface. The diaensions of his study areas were shout 200 by 500 feet, the long dimengion occurring parallel to the beach, and the ghorter one extending between the upper swash linit and the breaker zone. Ingle found that patterns of tracer distribution were better doveloped 1 the uncer was released at several polnte along a Ine rather than at a single polnt. Te detarnined the cotal amount of tracer in the study area at givan intervals of time by wultplytug the value of aach tracer 1sopleth by the axea within the 1sopleth (obtained by plantmeter). Ia this way the depletion rate, or percent anouat of tracer leaving the area in untt of time, was found. The average velocity of the tracers was then obtained by dividing the average distance of travel (central injection point to asin exte from study area) by the tine required for half of the inftial tracer quantity to be depleted. Thls procedure is berewtin cermed the area-integration or depletion athod of estimating average particle velocities. To obtain net sand transport valucs, 
Ingle points out that ons has to derive value for the thickness of the wobile sand layax, the lintes of which are not precisaly known at preatent. Elnstein (1948) estimated the thickness to be only a few grain diameters, dopending on the location and sverage and grahid diameter thare. Work1ng Wth avaliasle sand volupe data from anglnealng atudies, Ingle utilized the following exprassion:

$$
\bar{\nabla}_{\mathrm{za}} \cdot \mathrm{A} \cdot \mathrm{B}-\overline{\mathrm{Q}}_{1}
$$

where ${ }_{\mathrm{g}}$ - average Annual tracer velocity: $\mathrm{A}$ = average annual unte sand transport (avtrage annual beach width $\times 1.0$ ft.); B whlckness of mobile bed: $\bar{q}_{1}$ - estimated average anmul rate of 1 tteral drift. Solving for 5 , several thicknesses were found for different areas and a correlation of moblle bed thickness wth average nedan grain diantar was developed. Typlcal values of $B$ were found to be 0.05 and 0.10 inches $(0.12$ and $0.25 \mathrm{~cm}$.

Another means of quanthfying sand novenent Involves use of the tme-Integration method, developed in laboratory axpertuents by Cricksore and Lam (1962a: 19628). Its renceple concepts vere adated for use in the Ileld by Bruun and Purpura (1964), Yasso (1965), and Bruun (1965). The assance of this nethod is the delineation of "ade" or maximum tracer concentration which noves progresslvely downdrft in the Ilttoral zone under the influence of the longshore current. At sone point down beach, aapling ia done at close intervals so that a curve of the frequency of cracer recovery versus the way be developed. The apex or central polnt of the curve ylelds the sean travel time of the tracers; the diatance traveled being known, the average veloctty of the grains is obtained. Usually thi method requires extensive sampling for full development of the time-frequency curve. For this reason, Bruun and 


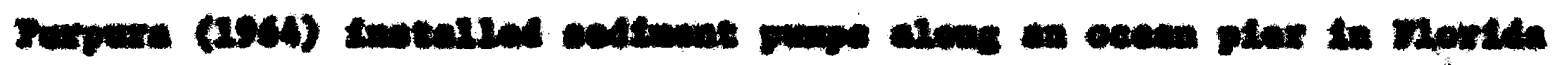

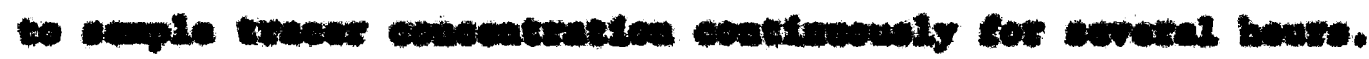




\section{PRESENT STUDY}

\section{Description of Area}

The beach selected for study is located south of the borough of VIrgInia Beach, Virginia, on the Atlantlc Coast (f1z. 1). A11 measurements and satrles were taken near a fence perpendicular to the shoreline, whlch marked the boundary between Virglnia Beach and Caxp Pendeltor, a milfary training area. The study area will herester be referred to as the "pendel ton Transect".

The terninology assoctated wth the study of beacher and uad in this papor is the sane as that given by Ingle (1966, po. 12-13). PIgure 2 (A) shous the classical beach profile and assoclated terminology and figure 2 (B) represents the divialon of an Ideallzed beach into dynanfc zones. Besches wth steep foreshore slopes often lack surf zone at higher tidal Levels; however, due to a relatively flat foreshore slope (about 6 deg.), this zone was usually well-devaloped at the Rendelton Transect during the per1od of study (1ate sumex of 1966). A sall secondary breaker zone somet lmes developed batwen the swash and surf zones. Flgure 3 shows in plan view the topography in the vielnity of the Pendelton Transect, as obtalned by leveling on september 17,1966, the date of the aln tracer experiment. After visually locating the lfmito of surf and mash backwash in ralation to maxker rods shown in figure 3 It was found that the botton slopes reflected a sinflar delineation between the Inner two zones deplcted in flgure 2 (B). 
Waves approsch1ng the Virginla Beach shore may attain breaking helghes of six feet or more, usually from swall generated by distant ocean torws. The normal breaker height, however, 1 probably between three and four feet durfng sumer snd arly fall months, the breakers being elther the plunging or spliling type. offshore bar and trough gystems superimposed on a gently aloping botton frequently set up multiple breaker zones. Having passed chese zones, the find set of raves fraplng Ing on the beach generally have amall angles of approach (the orthogonals to the wave crests deviating no more than 10 degrees frow the diraction perpendicular to the shoreline). Regardiess of their 10w angle of approach, the net ffect of large anplitude raves is an alevatad water level which, cowblned with aven a slight wave angle, noratly produce faixly strong longshore current. The effects of the waves on the beaches are only slightly moditied by the relatively low mean tidal range of 3-4 feet at Virginia Beach.

In addition to the present Investigation, other atudies (Harrison and Horalea-Alamo, 1964; Larrtzon and Wagaer, 1964; Harrison, et Al." 1964; Harxison and Krumbeln, 1964) have been conducted in the VIrginia gach ares dealing with varlous aspects of the local beach-ocean environment. The information in these reporta gulded the development of the present study.

\section{Design of Experiment}

Model Selection - A primary tep in planing a new experinent sucil ss the present one is that of proper experinental design. The tudy of beaches has been factlitated by the use of a variety of nodels, including scale models with dinensions reduced for ease of measurement. Whenever measurement data are being collected, matheratical models are very often 
used, these being elther the deterministic or the statistical type. Deterministic models utilize varlables and constants but lack a statistical component so that, measurement errors excluded, all relationships set forth must be exact (Krumbein and Grayb111, 1965, pp. 15-17). An example of a deterministic relationship that is often involved in beach problems is Stoke's lav which relates the terminal setting velocity of a small sphere in a flutd to the difference in density between spere and fluld, the acceleration of gravity, the square of the sphere's radius, and the viscosity of the Fluid.

In a satistical model, values of one or more of the functional components is random.' A conmon example is the simple I1near model (Krumbein and Graybi11, 1965, p. 224) which way be expressed:

$$
x=a+B x+e
$$

where $\mathrm{Y}$ is an observable random quantity, $\mathrm{X}$ is an observable quantity that is not random, $\alpha$ and $\beta$ are unknown parameters, and e is an unobservable random error with mean zero and vartance $\sigma^{2}$. The above expression 18 termed linear because of the way the parameters $\alpha$ and $B$ are related. Hence a number of observations result in several simultaneous IInear equations which can be solved for $\alpha$ and $\beta$ by the method of least squares, whereby e is mininized. The sinple linear model is easily developed into more complicated forms by Increasing the number of unknown parameters and their corresponding Independent variables which may themselves have added complexity (e.g., $\mathrm{x}, \mathrm{x}^{2}, \cos \mathrm{X}$ ). A solution to any Iinear model consists of finding a combination of parametric values that 111 reduce $e$ to the lowest posstble level so that $Y$, the dependent varlable, can be computed directly from subsequent sets of independent

I'In connection with probability and statistics, the term randon Implies collective or long-run regularity" [Glossary of Meteorology, p. 467, 1959]. 
variable daca. The final equation, then, nay be termed "predictor" aquation, where the independent variable(s) are chlled predictors and the dependent variable is called the predictand.

Although number of deterainistle models have been speciffeally developed for the beach environment, nost of then have had IImfted success as predictors of actual beach cond1tions. For exanple, an empirical equation to predict grain size and sorting patterns in the offihore zone on the basis of wave helght, length, celer1ty, at111 water depth, and partcle fall veloctty was developed by Ippen and Eacleson (1955) In laboratory tudies; assuraing this relatlonshlp would hold under certain equilibriun condttions, M11er and zelgler (1958) found good approximation to the sane under 1doal fleld conditlons, but later found 11ttle correlation where botton topography was Irragular (MII and Ze1gler, 1964).

Because a variety of aechanical processes are functloning at any given time in the beach environaent, it is not surprising that good agreement between fleld observations and the corresponding theoretical values of a ingle deteralnistic equation is seldom attained. Posibly, When all or most of the basic processes are understood, the behavior of the beach environment w11 one day be completely described. However, unt11 these theoreflcal concepte becone fully developect, it may well be that the statistical model has more to offer the marlae scientist engaged in fleld work. A particular type of atatlatical model that has found Increasing use in recent years, the stochastle-process model, w111 be examined in the present study.

Stochast 1e-process Models - The word stochast1c 18 synonymous wth probabilistic, and was origtmally uaed to signify a glven phygical or blological process having randon changes assoclated with it which could 
be dealt wh through the lawa of probability (3artlett, 1960). More recently, the definition of the teratochastle procass has been glvea as "... a family of randon variables wlth lnfinftely nany meaberg" (Krumbetn and Grayb111, 1965, p. 375). Doob (1953, p. 46) stated that such a

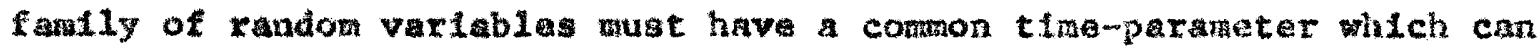
be exther continuous or discreta. An example of a stochastic process present in the ocean environent is the randon distribution of wave heights, $X$, having a continuous time-parameter, $t$, so that $X(t) r$ preaent time-dependent populations of wave heligt over some tine interval. For any fixed time, $t$, the sinultaneous mesurement of all waves In an area would reveal the true distribution of $x_{\text {at }}$ at that instant (thls 1 now belng done with synchronous atereo-patre of aerlal photos). However, for given interval of tine, an infinite number of hetghts of waves, $X(t)$, exists. Other stochastlc-process sacdels may have discrete time-parameters wherein certain events (e.g., radioactive emastons) occur randonly at discrete tiats. It nay be noted that randon distributions thaselves may be contlnuous, as are the normal, lognormal, and gansa distributions; or discrets, as are the binowal and polsson distributions.

Stachastc-procese wodels are becoming Increasingly important In describing natural phenonena. Scheldegger $(1953,1964)$ assumed

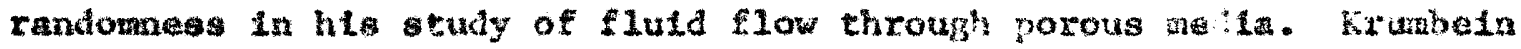
(1967) fves examples and 11lustrationg of karkovian processes used in airulation of stratigraphe sections. A stochastle trechanksa, the simple Markov process stipulates that the atace of a system at che $t_{x}$ polat $x_{x}$, or event $k_{r}$ is dependent upon the atate at $t_{r-1}=x_{r-1}$, or $E_{r-1}$. Another type of stochastic procese, the randon-malk nodel, has lean used 
by Leopold and Langbein (1962) to descrtbe drainage networks of connecting rivers and streans. Scheidegger and Langbein (1966) also discussed random-walk models as applicable to transport processes used in determining the random evolution of landscapes, gtating:

The transport process has a stochastic element in it, that $1 \mathrm{~s}$, there is a random element determining which "particle" moves at what time so that the transport process can be regarded as the result of "randon walk" of the Individual "particles" maklng up the landscape... . the process is not truly random since the small scale effects Involved are all mechanically completely determined. However, the mechanics of these sinall scale effects is so complicated that the details concerning most individual particles will remaln forever unknown. ( $p . c 3$ )

Accordingly, processes sImflar to the random-walk transport model are necessarily belng recognized in quantitative analyses of sand transport In the dynamic zones of beaches (Ingle, 1966, p. 40). Here sedinent motion 1 caused by a combination of sheer stresses generated by wave and current actions (Bruun, 1965) with individual particles alternately moving in teraporary suspension within the fluid medium and along the botton as bed load. Additional dispersive stress resulting fron particle collisions alds in transferral of mowentur to both sand grains and fluld medtun (Bagnold, 1963). Further complexitles are found in unique relationship between grain size, settling velocity, and fluid "threshold" velocity required to inftiate grain motion, as explained by Hjulstrom (1935) and Inman (1949). A11 of these effects Interact to create random patterns of grain motion in the fleld, perhaps nowhere better demonstrated than in studies ut1lizing fluorescent tracers. Tracer Particle Displacement Model -- Recognizing the Inherent varlability in the movement of sand particles in an active nearshore environment, a decision must be made as to which variables, spatially and 
temporally, w111 be considered as having random distributions. In this expertiment, the displacements $X$ and $Y$ of an Individual tracer particle from some arbitrarily placed origin $(X=0, Y=0)$ at time $t$ over the interval $0 \leq t \leq T$, were selected as random variables. Th1s formulation clearly invokes the stochastic mechanism as previously defined, since at any fixed time, $t$, there w111 be two groupd of displacements [X(t), $Y(t)]$ represented by a large number of tracer particles recovered after havins been released at a single point $[X(0), Y(0)]$ and acted upon by waves and currents during the time interval 0 to $T$. In other words, the random variables selected have spatlal coordinates and are subject to a continuous tlme-parameter within the framework of a stochastic process. To Implement the above model, arow-column sampling grid was devised ( $f 1 g$. 4) with each sample located by $X$ and $Y$ orthogonal coordinates. $X$ values were made to increase in a northerly direction parallel to the shoreline with $Y$ values increasing in the onshore direction. The origin of the coordinate system was placed in the lower left corner of the grid as Indicated in figure 4 , so that all $X$ and $Y$ values would be positive. Fluorescent tracers were released at predetermined, centrally located points within the grid, and samples of sand were collected at eegular Intervals of time at each station shown in figure 4. The data thus obtained were grouped according to the time of collection, assuming simultaneous sampling of the entire grid, so that the distribution of particle displacements as represented by $X$ and $Y$ values could be examined Independently with reference to a common time-parameter.

\section{Execution of Expertment}

\section{Preparation of Tracers -- Numexous methods of tracing sea-bed} materlals have been used. The nethods fall into two categorles; namely, 
those which utflize radioactive coatings or axtiflctally-induced radiation and those which use contings of luorescing dyes and pigments on selected natural objects (rangtng in atze from clay to cobble). Due to the hazards of radioactive substaces, this type of tracer has been used rosty aftshore (Inman and Chamberlatn, 1960) and along restricted beaches (KLlson, et al., 1958; Inose and ShIraishl, 1956). Fluoreacent dyes are much cheaper than radloactlve tracers and offer no potential danger. hence dyes have been fax more extenstvely used. The frgt use of a fluorescing compound to mark tracer grains is attributed to the Soviets (Medvedev and Albulatov, 1956). Since their work, acientists in many countzles have exployed fluorescent tracers, thetr methods defering wainly in the type of colating procedure and the conpounds used. Wright (1962, pp. 2-3) and Ingle (1966, p. 10, Appendix 1) fve good aumancles of the work and wethods used fin fluorescent tracex studies to date. Por the present sudy, wethod devaloped by yasso (1962) was ayloyed. Yasso ut1lized comaercial srade of fluorescent acrylic 1acquer ("satety palnt") to whleh he added a guantity of bonding agent constating of toluene and bettle resin before apylying th th thin coses to dried gratos of sand. The application of this lacquer to large quantitles of cand is done easily and at very low cost. Yasso's recomendatlons re followed closely in this study except for the thod of application: 1.e., the rixture vas introduced Into a large plastic bag containing the required anount of and and then ahaken by hand. Approxlmately 100 1bo. of sand was dyed using DaymGlo no. 202-18 (8Ignal (5reen) acrylic paint with bonding agent and allowed to dxy. When dry, the tracer waterial was worked with pressing tool to elluinate clups which had about the same congletency as those of sugar. 
Samples of the dyed zrains were axamind under a tcroscope using longwave ultraviolet 11 ght to deteralne the nature of the coating. Most Grains contalned patches of dye in sull crevices, not affecting the latial size or shape of the gratn algniflcantly, yet providing a brilliant source of light for postelve ldentification with the unalded eyc. When mixed with undyed and, aingle tracer graln anong thoueands of ordinary gralns could be quickly datacted.

The mterial salected for dyaing was an almost pure quartz sand taken from the dune area of the beach. Defore balng treated, each quantity collected wa passed through 30 men screen and shakea vigorously on a 50 -mesh screan so that the final quantity retalned fell wtiln the size range $0.29-0.59$ wa This alze range clooely approxinates that of numerous nearshore sand sampleg taken from several VIrginia Seach Localfties, whose cotaposition was alniy quartz (Harrison and Morales, 1964, pp. 34-35).

\section{Infection of Tracers and Sareing Technique - A single tracex}

expertuext was consucted at the time of high clde on the morning of September 17. Seeding was done during the tine of maxinal tidal height ao that sea level change would be aininal during the experiment (minfma1 tidal height would have sufficed as vel1). Approxtmately 100 lbs, of cracer and, divided into four equal portions, was released at the Pendalton Transect at the positions shown in figure 4. The positions were chosen to favor southerly drift ladicated by the preance of Salrly strong longshore current. The tracer was releaged at four polnts along a line perpendicular to the shoreline to ald the inftial dispersal Stro the swah and suxt zones, as recowended by Ingle (1966, p. 21). It may be noted (figure 4) that the mean postion of the tracers at time 
$t=0$ nay nevertheless be Imagined as a single point $(x=125 \mathrm{ft}$. $Y=37.5 \mathrm{ft.}$ ) along the boundary of the two dynamle zones. For analyses of Ifsplacement distributions, 211 grains were constdared to have entexed the gysters at that point.

The reledse of the tracers was accoplished by transporting the four quantities of sand in plastic bags to the release points, whereupon they were placed on the botton and torn open by hand (ualng four assistants to achieve a simultaneous release). Frior to release, wetting agant (comercial detergent) was mixed with the contents of each bag.

Sampling of the tracer distribution was conducted at 10-zinute Intervale up to 50 minutes after release. Tho apeclal coring devices (f13. 5), designed by the author, were used along colums AA, BB, CC, and DD (fig. 4), and hand sampling of the upper $0.5 \mathrm{in} .(1.3 \mathrm{~cm}$ ) of the aand aurface was done along colums $A B, A C$, and $C D$. The lattar group of samples aupplewented the core samples. The cores wete taken in short (8.0 In., 20 cm.) cellulose acetate butyrate tubes of 2.0 in. (5.I cr..) dianeter by driving, them into the bottom whth the cortng device (valve opez), then extracting the core (valve closed) and quickly gealing the bottom end with plastic cap. Cores were marked and muedlately carriad to shore by two tean of fleld assistants. The average tine required to ample the antire grid was about four thutes.

Owing to a tendency for beach sands to travel $1 \mathrm{n}$ a mobile layer of Itrited thickseas, as mentloned in prevlous investigations, it was deemed necesary to obtain core sumples such that the gratns lmediately beneath the surface would have ma equal charce of appearing in the sample. In addition, the presence of a rippled bottom was noted. N1pple ersta 
are known to Igrate at low fluid velocities (Shepard, 1963, pp. 116-117), and their movenent was expected to advance and bury some grains, while exposing others in the following troughs. These in turn were carried forward over the crests. Therefore, because marked particles could be rather quickly incorporated into the bottom, the top $0.5 \mathrm{in.}(1.3 \mathrm{~cm}$. of each core was saved for counting purposes. Becaune a larger number of sand samples were desired than there were plastic tubes avallable, 18 of every 42 amples obtained were collected by hand (getting approximately the top $0.5 \mathrm{in.}$. $\mathrm{sand}$ ) and stored in small bags. These samples were later divided in the laboratory to obtain a quantity of sand aqual in volume to that taken from the sand cores.

Measurement of Environnental Factors - A number of dynawic factors were measured near the time of high tide the morning of September 17 and also during the preceding high tide. These factors Include the following:

Man height of breaking waves $-\mathbb{R}_{b}$

Thla value was obtalned by measuring the trough to crest distance of Ifty consecutive vaves using portable clde ataff graduated in feet and tenths. The weasurement error was estimated to be $\pm 0.3 \mathrm{ft} .(0.1 \mathrm{~m}$.$) .$

Mean height of agnificant breakers - $\bar{H}_{b s}$

In the set of fifty consecutive waves, the highest one-third were avaraged to get an extinate of the gignificant wave height. This procedure tends to 1solate the higher amplitude waves present in the wave spectrum as the wain contributors to the total wave energy.

Mean pertod of breaking waves $-\bar{T}_{b}$ The beglnning and ending times of a set of wave neasurements, 


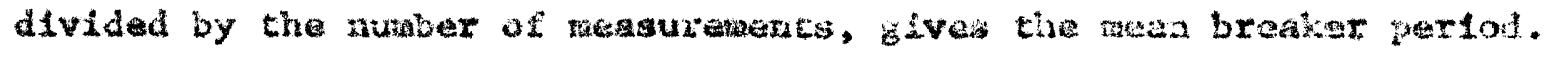
Measurement exror was ascinded as \pm 0.2 secon.

$$
\begin{aligned}
& \text { Significant wave heights - } H_{\text {e }} \\
& \text { (Average helght of the } 1 / 3 \text { highest waves) }
\end{aligned}
$$

Values were obtalned from a 1 ignificant wave strip-chart analyos of wave records fron the Coattal Englneering Research Centar's stanrasistance wave gage located at the end of a 950-ft.-1ong fishing pier (approxlmately $1000 \mathrm{yda}$. north of the Pendelton Transect). Water depth

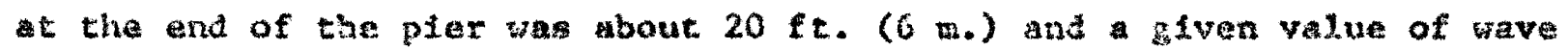
hasht la procise to about \pm 0.1 w.

$$
\begin{aligned}
& \text { signiflcant wave perlod }-T_{\text {g }} \\
& \text { (Avarage perlod of the } 1 / 3 \text { blghest waves) }
\end{aligned}
$$

These values were obtalnd in the analyses for $u_{S^{*}} T_{s}$ is datermined to the nearest $0.5 \mathrm{sec}$. In the ranse 3 to $6 \mathrm{sec}$, and to the nearest whole second for values above 6 sec.

$$
\begin{aligned}
& \text { Mean acute angle between the ahoreline } \\
& \text { and the crests of breaking waves }-x
\end{aligned}
$$

This angle was measured using a tripod-mounted bearing circle equipped with sights and placed as cloge to the Inshore margin of the brakers as posable. After elghting along line parallel to the shore11ne, then turolog to a 1 lne passing through the breaker crests, the breaker anglo wa recorded as the angulax difference between bearingo rest; a man value was obtained frow thee such readings (prectalon atas probably \pm 2 degrecs).

Mean trough to botton Lisarace.

in front of a braking wave - $\bar{z}$

Th1. distance vas measured directly and averaged for five Individual observation, giving a measurenent error of about $\pm 0.51 \mathrm{n} .(1.3 \mathrm{~cm}$.$) .$ 
Mean lousshore current velocity $-\overline{7}$

Estinates of the wavenduced longshore current were obtaineu

In the surf zone by releasing fluorescein dye in the water and tining the movenient of the center of the dye patch over known distance.

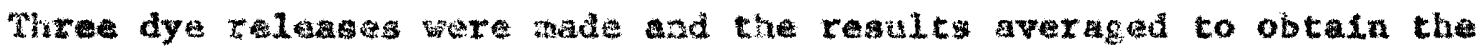
mean cravel tine. This value was then converted to mean current veloc1ty aftar woting the distanca and diration of travel.

Mean wind alrection and epeed $-\bar{W}_{d}, \bar{W}_{s}$

A Weacher Bureau Model 420 wind vane and anemometer with direct readout module was installed at the end of a flshing pier (f1g, 1C) at V1rginia Beach. Hean wind direction was racorded to the neareat 5 degrees and mean wind speed arror probably whin 2 wles pex hour.

$$
\text { Sae water denelty }-p_{t}
$$

A Taylor mercurial tharmoweter mounted in atandard UsGsGS water sampler was ssed to record water temperature to the nearest $0.2^{\circ} \mathrm{C}$. Water samples were collected and stored in cltrate of magnasa bottles for later determinations of salinity in the laboratory ualng A vitech induction salinoneter. Sea water density $\left(\mathrm{g} / \mathrm{cm}^{3}\right)$ was doteruined stom the tomperature and galintty ustng a U.S. Maval ocenographle OtEsco nomograms.

Hean alope of the foreahore - w

Foreshore slopes wer detarmined from cross-sectlonal data Ised In cosputing $Q_{\text {f }}$, which is described in the followlag paragraph. Tha preciston of a given slope mensuremert is a vout \pm 0.2 degrees. 
Meari settling, veloctty and

foreshore changes $-\bar{U}_{s}$ and $Q_{f}$

Data were obtained regarding the vertical fluctuations and slze composition of the beach surface. Rods placed at approximately 20-ft. Intervals along the main transect were marked near their upper ends and referenced to mean sea level through a leveling network. During the tidal extremes in question, measurements were made of the distance between the sand surface and the reference mark at each rod; also, a small quantity of sand was collected near each rod by scraping off the uppermost layer of grains. These measurenents and samples were saved for laboratory procedures, to be describad shortly in which $q_{f}$, the quantity of sand eroded from $(-)$ or deposited upon $(+)$ the beach foreshore in one tidal cycle was calculated, along with the mean setting velocities, $\bar{U}_{s}$, of the individual sand samples.

All data pertalning to the environmental factors measured in the fleld are presented in table 1, in both English and wetric units. It is intended that these measurements should serve to convey the general environmental conditions prevalling just prior to the beginning of the tracer experiment.

Laboratory Work Method of Counting Pluorescent Grains - Core samples coilected during the experiment were later extruded from their plastic iiners and the top $0.5 \mathrm{in} .(1.3 \mathrm{~cm}$.$) removed with a small spatula. Each quantity$ of sand thus obtalned $\left(1.6 \mathrm{In},{ }^{3}, 26 \mathrm{~cm} .{ }^{3}\right)$ was washed and dried prior to examination under long-wave ultraviolet light for an iajclal escinasion of the tracer grain content. Samples estimated to contain approxtiately 100 tracer grains or less were left intact wille trose estimated

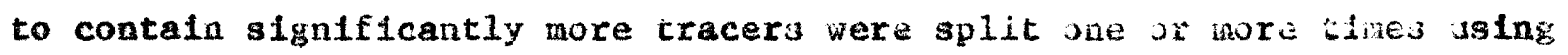


a CARPCO tcromplitter. Lach ample or subsample was then spread evenly, a portion at time, over a rectangular grid in a counting dish and noved about thth amell probe to insure exposure of all tracer gratns. The total nuber of cracers tr the dish at one time was obtalned by suming the number of fluorescing particles in each grid square, as viewad In turn under a low-power stereo mleroscope. For samples that required splitting, the total number of tracer grains per untt volume was estlated by wultiplying the subsaraple count by $(2)^{N}$, where equals the nuber of thos the original sample was mplit. The supplenentary hand sample were split to obtain the approxlmate unt volume of the core saxplea, then the saples vere subjacted to the asual counting procedure.

A number of duplicate counts ustng the same flald sample were compared for an analysis of the counting error; except for samplea wth very sall tracer concentrations, thls error usually varted betwaen 2 and 3 percent, Tracer concentrations for the 42 samples of the sampling grid (fig. 4) are listed in table 2.

Method of Kapid Sand Anelys1s - - Sand camples collected during the experlment, Including the samples subjected to tracer counting procadures, were andysed using a Woods bole Rapld Sand Andyzer (Zelg1er, et al., 1960). The Instrument was modifled, having a fall tube with a 4.0 in. (10 cn.) I.D. Instead of the standard 2.0 in. (5 ca.) I.D. and having an impoved release mechantam conatsting of a 250 -mesh screen applicator ingted of gate-type device. The basic procedure followed for the prasent analyses has been outlined by hiverioon and Moralas-Alano (1964). Briefly stated, the procedure consiated of placting a 7-8 ga, sanple (prevlously washed, drted, and split) on the acreen applicator and weting 1t. This ls followed by invergion of the aample 
and application to the water surface at the top of the fall tube (rupture of surface tension effects the actual sample release). As the first few grains reach the lower $11 \mathrm{mlt}$ of the pressure fleld (1ength - 1.0 R.), a mark Is ade on the accompanying pressure-time curve to establish plateau value representlag 100 percent sample pressure (weight). Beyond the plateau mark, falling pressure values and corregponding tines are noted at five percentile points $\left(P_{5}, P_{16}, P_{50}, P_{84}\right.$, and $\left.P_{95}\right)$ and used to compute the mean setting velocity, $\overline{\mathrm{U}}_{\mathrm{g}}$, as

$$
\begin{gathered}
\bar{U}_{s}=\frac{100}{\bar{T}_{s}}(\mathrm{cm.} / \mathrm{sec} \text { ) } \\
\text { where } \quad \bar{T}_{s}=\frac{\mathrm{F}_{5}+2 \mathrm{P}_{16}+4 \mathrm{P}_{50}+2 \mathrm{P}_{84}+\mathrm{P}_{95}}{10} \text { (sec./5.) }
\end{gathered}
$$

Precision egtimates of particle setting velocity made by successive runs of a sample of green tracer were approximately \pm 0.10 cm./sec. All samples were analyzed in fresh water and vere corrected using the tables of Zeigler and Gill (1959) to standard settling velocities at $24.0^{\circ} \mathrm{C}$.

Figure $6 \mathrm{~A}$ is a graphic representation of $\bar{U}_{8}$ varylng with distance along the Pendelton Transect during the times of two adjacent high tides. PIgure $6 \mathrm{~B}$ is a contour map of the distribution of $\overline{\mathrm{U}}_{\mathrm{g}}$ within the area of the tracer study on September 17 at 11:00 AM. These distributions are important to the study in that they show the extent to which the green tracer sand watches the in-situ sand as regards setting velocity; $1 . e$. figure 6A indicates 11ttle net changes in values of $\overline{\mathrm{U}}_{\mathrm{g}}$ over one tidal cycle, and figure $6 \mathrm{~B}$ shows that $\overline{\mathrm{V}}_{\mathrm{g}}$ for the tracer $(4.16 \mathrm{~cm} . / \mathrm{sec}$ ) falls at the lower end of the in-situ range of $\bar{J}_{s}(4.0-6.0 \mathrm{~cm} / \mathrm{sec}$.$) . Inasmuch$ as the latter amounts to a range in grain diameter of $0.29-0.40 \mathrm{~mm}$, for a Corey shape factor of 0.7 (Zeigler and Gi11, 1959), the matching of 
average in-gitu tracer partcle la was ahleved, therafore, to whin 0.1 m. Regardles of the degree to which tracer particlas anteh 1n-1tu partfclas in siae, it is evident from the distribution of $\overrightarrow{\mathrm{v}}_{\mathrm{s}}$ shown in figure 68 that a cartaln amount of size sorting occurred within the area of study. Thus, the inshore 11nit of the swash zone (f1g. 3) and acattered areas wtiln the aurf zone (hatched contours of fig. 6B) have low $\bar{U}_{\mathrm{g}}$ values, and are visualized as "slnka" towrard which the

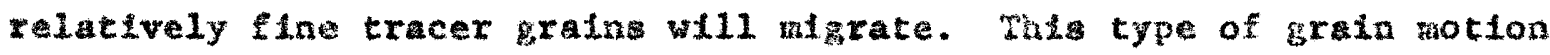
Is viewed as an laevitable occurrence in a changlng atcural environment such as that of an ocean beach, and sust be consldered an integral part of the overall movement of beach and due to the mofor transport mechanisms. Wherever the afects of sortud show a tendency towards local accumulation of tracar particles, one must dapend upon appropriate statist1cal wethods to separate local varlations from regloonl trends in particle distribution. These methods wlll be discussed later.

\section{Method of Cosputing Boreshore Eroslon-DepositLon - Changes in}

elevation of the beach surface were used to compute $\mathrm{Q}_{f}$ the volume of sand exoded from (-) or depositad upon (+) the foreshore over one tidal cycle, or betreen successive high thas in this instance. Llevational data obtalned from rod measurements before and after one tidel cycle were proflled at a $1: 1$ reduced scale on $8 \mathrm{ft}$. length of K. AD. Albanene papar. Flare 7 show schenatically how the areas between two proflles (neasured by planimeter), when aultilied by and bach length, gave the net chane in volume, fe. Due to saall changes in elevation, proflles were carefully drawn on large scale tn order to avold exceafve measurement arrora. These errors were probably less thas \pm 2.0 Et. ${ }^{3}$ for frial estiates of $q_{1}$ 
Data Aralysi:

Distribution of Tracers - A prelluinary anslysis of tracer distribution ta space and time was undertaken to deteraine the nature of resulting dispersal patterns. The tracer concentration date (table 2) were grouped into five row-colum atrices, each representing a single sampling time. Because of the physical evidence for two distinct dynamic zones (p. 3), it was deemed necessary to tist to see if the forces present in the two dynanic zones produced stgnificant differences In the distribution of the tracer particles.

For each of the five sampling tines, the tracer concentration data vere stratified tnto two groups; nasely, counts made in the swash zone consisting of the shorewardwost four rows and seven columas of the original data grid, and the counts made in the gurf gone conslating of the seawardmost fowr rows and seven column. Thus, an overlap of one row was planned between zones. After sumplng colum values for each zone, a ch1-square test for homogeniety (particle displacement In the swash zone versus particle displacenent in the surf zone) was made for each of the five samping times. The results (table 3) indicate that the data are not hoinogenous and the displacenent values of the two zones should not be analyzed as one.

Fourler Trend Surface Analysis -- Trend analysis offers an objective method of exanining mappable data. This technique involveg the computation of mathematical surfaces of "best fit". The wathematical derivation of trend surface reduces the subjectivity involved in freehand drawlng of isopleths and often reveals in a relatively objectue manner the Inherent "trends" present in the data and also the extent to whlch these trends account for variations from the data mean. In this 
atudy trend analyaes were used to outline the baslc patterns of tracer particle dtapersion.

3asteally, trend surfacling is an extenston of the tmple Inear model (p. 10). For a siven set of mappable dats, the variation may be separated Anto two component:; 1) a mathenatleally dafined trend component, and 2) a restunal component, the deviation. The form of the trend component for polynomial functions is

$$
x_{n}=a_{0}+a_{3} u+a_{2} v+a_{3} u^{2}+a_{4} u v+a_{5} v^{2}+a_{6} v^{3}+a_{7} u^{2} v+\ldots
$$

where $U$ and $V$ are coordinate values locating the nth observation point: on a rectangular grid, $x_{n}$ is the value of a glven property at that point measured along an ordimate perpendicular to the $\begin{gathered}\text { grid, and } \\ 0\end{gathered}$ $a_{2}, \ldots$ are coefficients. For a given number of coufficients, $n$ equation (n observations) may be solved simultaneousdy, with the coefflctents as unknowng using least squares fitting. Substituting the coefficiant values into equation (1), trand surfaces may be computed for map presentation. This type of trend surface, known at the polyaomial trend, was flrst ubed by M11ler (1956) and has since been employed by twany investigators, amon: thera intten (1963) tho presentod an excellent sumary of nethods cogether wh th computer progran for perfoming the necessary calculationa.

A more recently developed type of trend surface knowa as the Pourler trend, has been deacribed by James (1966a). The reader is referred to this work for the detalls of the aethods involved. The bestc aquation used is a double Fourter sertes: 


$$
\begin{aligned}
& \alpha(U, V)=\sum_{i=0}^{K C} \sum_{j=0}^{L C} c c_{1 j} \cos (2 \pi 1 U / M) \cos (2 \pi j V / N) \\
& \text { KC IS } \\
& +\sum_{t=0} \sum_{-1} \operatorname{cs}{ }_{1 j} \cos (2 \pi 1 \mathrm{U} / \mathrm{M}) \operatorname{ain}(2 \pi \mathrm{V} / \mathrm{H}) \\
& +\sum_{1} \sum_{j 0}^{K S} \sec _{1 j} \ln (2 \pi 10 / M) \cos (2 \pi j V / N) \\
& \text { ks Rs } \\
& +\sum_{1=1} \sum_{1 j} \ln (2 \pi 10 / M) \sin (2 \pi j V / N)
\end{aligned}
$$

where

v the North-South coordinate axis Increasing to tho South and with oxigin at horthern ma edge

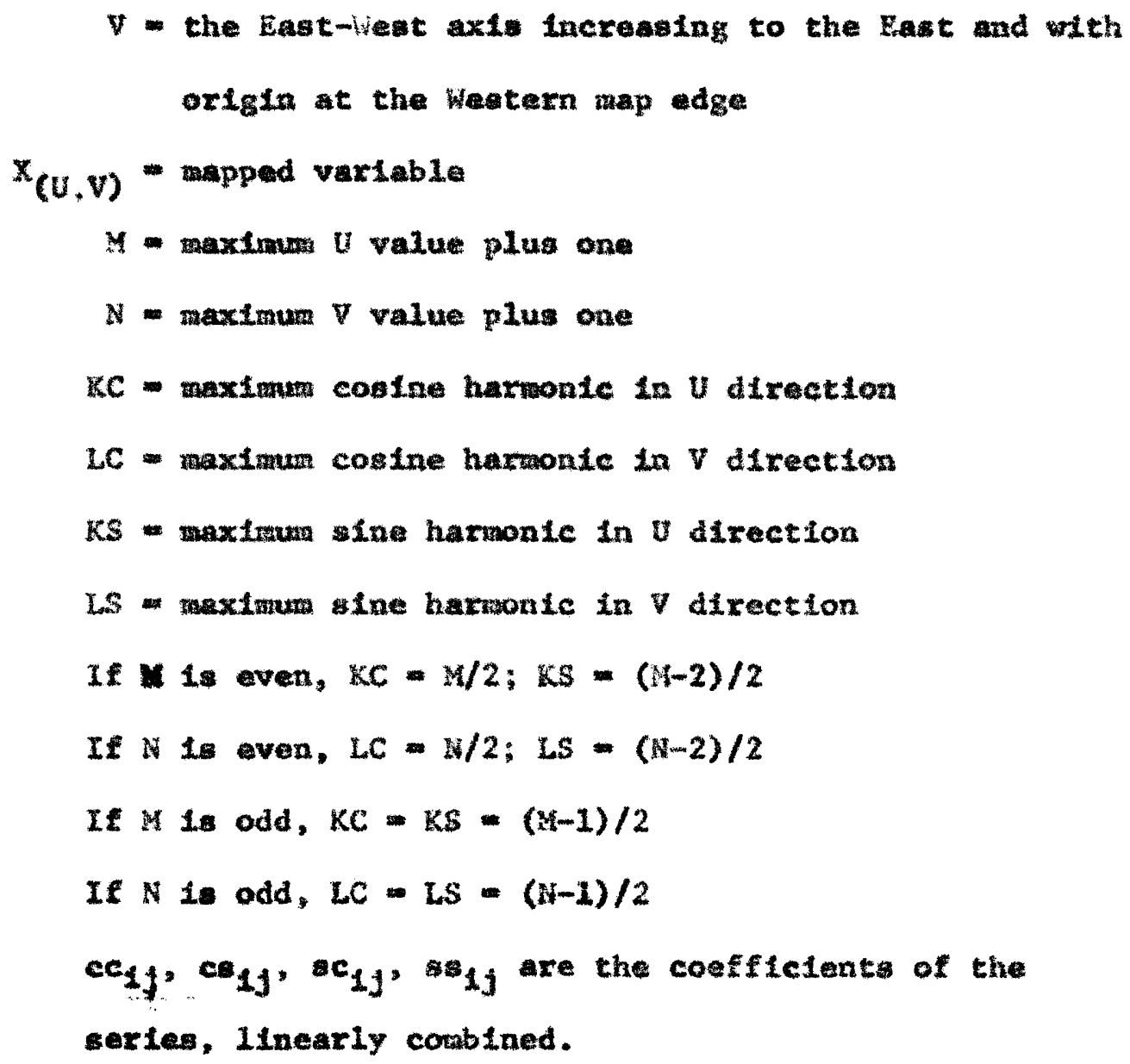

A comartaon of polymonial and Fourier trend surfacing techniques, has been preatented by Krumbein (1966). 
The Pendelton tracer concentration data, arranged in map fashion on the sampling grid (fig. 4) were analyzed by Fourler trend analysis using a computer program called FOURFIT (Janes, 1966b). The program imput requires values decermining the degree of the surface desired which is a function of the number of coefficlents employed. It was found that the 25 coefficients of the first and second harmonic terms produced surfaces of suxtictently high degree of fit to account for approxinately 80 percent of the total varlability. Varlability was computed from the following formula:

$$
s s(\%)=\frac{\Sigma X^{2} \text { comp }-\left(\Sigma X_{c o m p}\right)^{2 / n}}{\Sigma X^{2} a b s-\left(\Sigma X_{o b s}\right)^{2} / n} \times 100
$$

where $x_{o b s}=$ the observed value of tracer concentration at one point and $x_{\text {comp }}=$ the computed value at that same potnt. Equation (2) gave Information as to how well the tread surfaces fitted the actual distribution of data in each case. In general, whenever 80 percent of the variation can be accounted for by the trend surface, the "fit" of the conputed surface is consldered excellent. Another output value of program FouRTi was the computation of "F", which determined that each fitted surface was signifleant regarding separation of the mathematical trend from the deviation.

Figures 8-12 are continuous-symbol maps, produced by the computer, showing in plan view the distribution of tracer concentrations at five 10-minute time intervals (five data series). In place of areal dimension values $U$ and $V$ of program FOURFT, $X$ and $Y$ values were gubstituted in accordance with the previously defined grid system of this study (fig. 4). The map contours at 10-minutes indicate a single vell-deftned mode of tracer concentration with values steadily diminishing tharezrom. Some skewness $1 \mathrm{~s}$ evident toward the upper-left hand corner of the map. 
The 20 and 3 -ainute serles show the same shewess wh some southerly displaccment of the central mode. In addition, an overall decrease in the ragnitude of the concentration contours nay be noted. The 40 and 50 mintite series Indicate the development of a bimodal distribution of tracer concentrion with one mode occuring in the southerly (downdrift) direction in the swash zone and the other reseining near the release points in the surf zone.

The aforementfoned maps revel informat lon that would be afficult to obtain frow a hand-drawn contour map. Mathernatically derived surfaces nay show the effects of the physlcal mechanimns acting on the tracer grains amid the inherent variation present in any complex environment. One such mechanisn, particularly evident in nearshore reglons, is that of tubulent diffusion, and concentric gatterns of tracer dispersion about a point source have been predicted fron the theory of this process acting in flulds (Roberts, 1923; Maltiner and Jartin, 1957, ch. 16; Murray, 1967). Although better nodel for deplcting the effects of fluid turbulence on conservative properties undoubtedly exist, the Fourier trends of figures 8-12 appear to take into account these effects as well as those due to the application of fluld stress on randomly noving grains (1.e., tractive forces) to glve an approxination of the ideal distribution of tracers with t1me. Two features found in figures 8-12 are worthy of note, namely; 1) a gradual separation of the original tracer mass into two distenct concentratfons, and 2) a central or unimodal tendency witkin each of these concentrations. The first of these features further reveals a southerly displacement of the shorewardmost tracer concentration relative to the seawardmost concentration. Wth regard to the second feature, a cross-section throus one of the trend surface maxima in either the $X$ or $Y$ direction would strongly suggest 
unimodal distributions sintlar to those expounded by Brun (1965) and Yasso (1965) in the tme integration sethod (p. 6). Blvariato Data Analysia - Haviag obtained evidence from the Fourler trand maps of flgures 8-12 that the tracer particle concentrations shown therein had discerneble patterns in time, a mothod of quantifying: the movenent of the tracer particles (and thus the movement of the In-situ population of ordinary and particles) was devised. It ws intended that this method should follow the basic concepts of the stochastepracess modal ( 7.12$)$ in that a family of random vaxiables ghould be eraployed, all having comon tiwe-parameter. By deflating the fantly of variables in teras of spatial coordinates, appropriate statistical proceduras were adopted to analyze quantitatively the movenent of particles whose posiclons are denoted by these sare coordinates.

Considaring txacer recovery data, Inagine that the Ith particle recovered has cooedinates $x_{i}$ and $x_{i}$ with refermes to the sampling grid (f18. 13). At any time, $t$, the values of the coordinates may be considered as two separata components of the ith particle displacenent as measured Erow the grta origla although at the too the ith particle may, In fact, have laln a long way from this orfgla depending on where thig particle was injected into the oysten. The ith grain, then, upon its recovery becomes a single iten in a vapple consisting of wany such grains where two variables are belag exaralred, the $X$ and the $I$ displacenents. Such blvarlate data allows the motions of the grains to be treated as random. Employlug the concept of random particle displacenent, bar graphe of tracer gratn frequency versus $X$ and $X$ distances in feet are presented In figurea 14 and 15 , respectively. These graph were constructed by sumfng colum valuea to obtain the frequencles of the $x$ displacenents, and by suming row values co obtadn the frequenctes of the $I$ displacentents 
whinin two alighty overlapplag areas representing the swath and surf zonea (1.e., two $4 \times 7$ data grlds, p. 25). Although aet coordinate valuss $1 \mathrm{in}$ and $25 \mathrm{ft}$. Lncrente wore selected for sampling, the ent1re population of displaced particles (represented by the cotal number of gralns in $1001 \mathrm{bs}$. of tracer) could have asoumed any of an Infinite number of positions, hence, the horfzontal scale in the graphs of fieures 14 and 15 is continwous. One can speculate as to whether or not the particle displacementa approxituate a certain continuous batiatical curve, such as that glven by the nortal diatribution.

W2 thout testing for normality, most of the bar graph distributions In 1 gures 14 and 15 were assumed to be representative of nornal distributions on the basts of a visual comparison with equivalent normal curvea (solld 11nso in each graph). Theae curves were constructed according to an abbreviatad method from Krumbelin and Grayb111 (1965, pp. 181-183). Meglecting skewnas in some Instances (e.s." surf zone at 20 minutes, fig. 15), the asmuption of normallty was considerad rasonable for the majority of cases.

the mon for tatical reasures comonly applied to normal distribution were calculated for the dLplacement data of figures 14 and 15 using a revised verslon of computer program $3 \mathrm{AT}$ (Seynour, 1956), computer progran for obtalning blvarlate means and nedians. These measures were required in order to 1) axame the distributions of tracer d1aplacement palues, 2) deteralne where algnificant mean dfffarences occur, and 3) utilize these differences to muantify particle wotion. The following computations vere made and included in the output program IAT:

$$
S A=\sum_{1=1}^{\text {符 }} A_{1} \text {, sum of recovored grains, or sample size }
$$




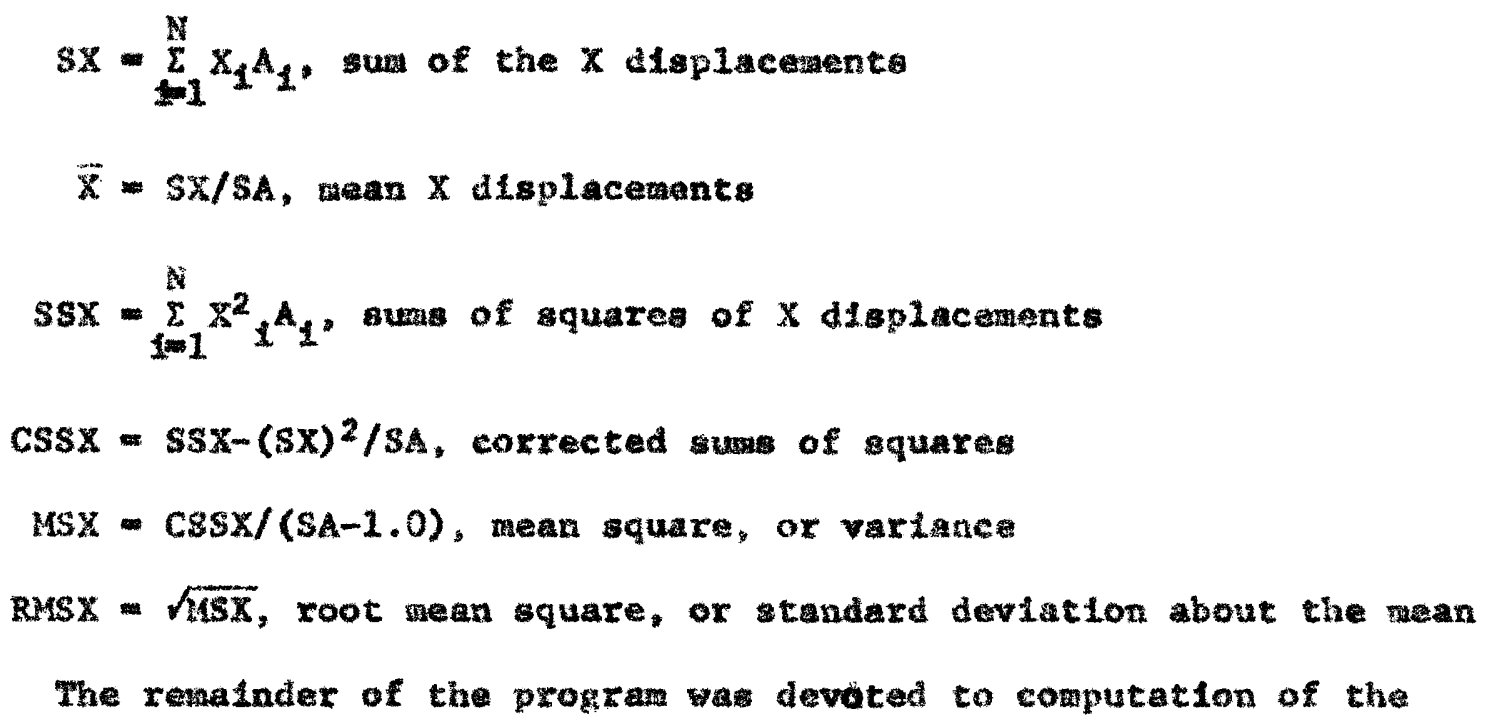

bivariace dian through an iterative least squares process. This measure locates the "center of gravity" of the distribution of $X$ and $Y$ values. Graphlc plots of the median for different times revaled highly erratic, and obvlously erroneous, patterns of tracer particle aovenent not anenable to further use.

Table 4 contalns the printed output of the MAT program pertalning to the displacenent means. The means were plotted against the five sampling tires of the experinent (f1g. 16) with confidence intervals at the 95 percent level placed about each mean. Examination of figure 16 reveals sevaral point of information concerning the tracer particle movenent in two dixactiona within the two zones: 1) in the $X$ (alongshote) direction the mean particle displacement values decrease almost Ifnearly with the in the swash zone, which is in keeplng with the directional senoe of the predefined coordinate system and is in agreenent wh the anotion Imparted by an exiating southeriy longhore current (table $1, \bar{V}$ ); 2) $X$ displacement in the aurf zone appears to be nonlinear over the 50 afnutes total travel tine with overlap of confidence intervals between some of the adjacent means; 3) Y diaplacetient in the awash zona remains almost constant, Indicating 11tele or not net motion of the tracer grains 
here In the onshore-offshore direction; 4) a net linear displacement exists in the offshore ( $Y$ decreasing) direction wthin the surf zone. It may be remenbered that the data points in figure 16 represent the mean of a group of displacements occurring at each point of elapsed time following the release of the tracers. This is a coneequence of the stochastic process and an Indication that simple linear regresgion of time on displacement, which some of the diagrams in f1gure 16 appear otherwlse sutted for, is not approprlate here.

\section{Comparison of Group Means - The information derived from}

f1gure 16 permits a qualitative analysis of the general motion of the tracer particles. It 1 s desirous that a quantitative analysis be made as well. Before an attempt is made to do this, two basic facts must be recognized at this polnt. First of all, only the tracer distributions themselves are followed through time; no Inforation exists about the paths followed by speciflc particles. Hence, one cannot "palr" successive particle displacenents of spectfic grains and use these as raw data to obtain a mean displacement covering the entre period of experimentation. Instead, at regular intervals of time $(10,20,30$ minuter ....) there are group means which can be compared successively. Secondly, an allowance must be made for an anamalous displacement at the time of tracer release which will affect particle displacements during the interval 0 to 10 minutes (fig. 16). The latter result is due to an unavoldable clrcumstance, the introduction of tracer into the upper portions of the water column during release. Normally, sand grains move by rolling or saltating at or near the sedinent-water interface, traveling much slower here than they would in the presence of higher fluid turbulence and advection at some distance above the interface. Therefore, gome time must be allowed for tracers to become fully entralned in the 
exigting sedimentary transport oystem.

Sach pate of adjacent (time-successive) proup mans of the particle displacomont data ware conpared for igntflcant differencos by use of the " $t$ " test at the 95 percent level of confldence (snadecor, 1956, p. 207). These tests were the bas Ls for Infarring and difference between the true populetions of tracer dipplacenents wheh could, in fact, be zero fridcating no net particle motion over the the interval spectfled. The results of the testa, stumarized 1 a tables 5 and 6 , Indicate lack of separation of ane of the group means for the $x$ diaplacenents in the surf zone, and the $Y$ dusplacenents in the swash zone. Where this occurs, a net particle notion of zero cammot be dLaproven. Accordingly, no further atcenpts to guantify the motion of tracers In these zones were madk, assualng that a lack of signiflcant mean difserence arywhere in the corresponding time-displacenent curve of flgure 16 meant efther a lacio of afgnificant net motlon over the entire perlod or that an accaleration (nonlinearity) within the motion was present.

\section{Ine-stratifleation of Maan Displacenent - Because of the} sigrificant diffarences between cach pair of group nean displacenent tested (tablas 5 and 6 ), the $X$ diaplacement values for the suash zone and the I displacenent values for the surf zone wore found to represent componente of nat particle notion of non-zero magnitude fin each case. A1so f1gure 16 shows pxonounced 11near1ty in the trend of group wean displacentents over the time intarval 10-50 min. for these particular conponents. These factors aliow one to consider the net wotion of tracer particles for the above zones and direcklons as being both fintte and

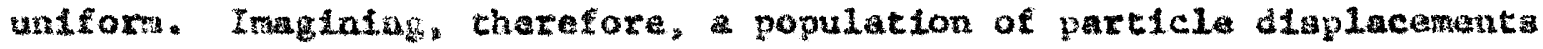
which vary only wht the (except for certaln anount of random vartation), 
a tiwe-seratifleation scheme can be ut1lized which will perate derivation of alngle mean displacement represantative of the enttro sapling pertod. An estruate of the nenn of the total population fs ada us ing

$$
\bar{s}_{w}=\frac{2 N_{t} s_{t}}{2 N_{t}}
$$

where $N_{t}$ is the number of 1 tens (particles) in the $t$ th atratum and $\bar{S}_{t}$ Is the sanple mean in the $t$ th stratur. Equation (3) is the weighted nean, in elther the $X$ or the $Y$ directions, of all tracer displacements. However, whereas values of $X$ and $X$ displacements have heretofore been zelactve displacements (relative to the zero point of an arbitrary grid system), values of $\bar{s}_{\mathrm{t}}$ will be wade absolute by the following foraulation:

$$
\bar{S}_{t}(X)=\bar{X}_{t}-\left(x_{0}+X_{p}\right) ; \bar{B}_{t}(X)=\bar{X}_{t}-\left(X_{o}+Y_{p}\right)
$$

In which $x_{0}$ and $\psi_{0}$ are the mean release poluts of the tracer at thae $t=0, \bar{X}_{t}$ and $\bar{Y}_{t}$ are the wean displacenenta in the $E$ th the gtratur, and $x_{p}$ and $\Psi_{p}$ are termed "Inpulae" diaplaceacents occurring during the flrst faw seconds after tracar releas. Values for the last two parawetar: must be estinated separately using regression technique. The Formula, (4), gielding ${ }_{t}(x)$ wII give postlve values whenever the displacement is positive in the sense of the coordinate system.

$$
\text { Regression Estmate of } \mathrm{X}_{\mathrm{p}} \text { and } \mathrm{Y}_{\mathrm{p}} \text { - The Inttil rates of motion }
$$

of the tracer particles, even when released close to the bottora, tere probably of a relatively high magnitude. Average atting velocity of the tracers $(4.16 \mathrm{~cm} . / \mathrm{sec})$ would acceunt for a second or two of suppension, such suspension belas augraented by the effects of fluid turbulence. In addition, wany tracer grains were deposited in quantitiee sufficlent to produce a slight local elevation of the bottow upon whlch Eluld forces would set to renove almost imediately working the gralns into pottions wore in equllibrium with the prevalling low reglme. 
wo direct method of estrote $\operatorname{lng}_{\mathrm{g}} \mathrm{X}_{\mathrm{p}}$ and $\mathrm{x}_{\mathrm{p}}$ la known to the author; therefore, rellance was placed on regresion eatinate ualag tho atandard equation

$$
\hat{d}=\underline{a}+\underline{b} t
$$

where $\hat{d}$ the dependent variable was chosen alterrately the $X$ and $y$

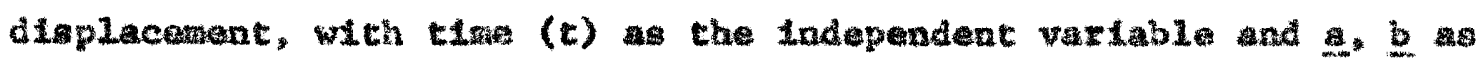
regreasion parameters. In this tagtance, it is the X-axis tntercept, a, that is required. Two astimetes of a corresponding to the $X$ and $\Psi$ directions were obtained by plotting the appropriate displactuent values individually agalngt trae uaing data given in table 2. These plots were not intended for predictive use, rather they were weans of estmating certain unique values, othervise unknown. The a values computed were a reflection of the expected displacenent at t t based on a form of extrapolation from the diaplacement at $t=10,20$, ..... 50 minutes. Pgure 17 show thls procedure graphlcally. Estrates of $\mathrm{x}_{\mathrm{p}}$ and $\mathrm{x}_{\mathrm{p}}$ were taken as the differences $(+$ or -$)$ betwen estimates of a and the corresponding release displacanents $\left(x_{0}\right.$ and $\left.x_{0}\right)$, undar the assumtion that the thae required to produce $X_{p}$ and $Y_{p}$ was very small compared to the lowest measured travel that of 10 mautes. Whis procedure adjuts the coordinates of tracer particle injection into the systam at 0 , thus inimizing the effects of impulatve (forced) tracer movement due to the method of release. The algn yalues of $X_{p}$ and $x_{p}$ are in accordance with the directional sense of the arid; e.g. an Initial Impulse, $x_{p}$, in southerly direction (decreasing $X$, 218. 17) would have a negative sign value. Regression analyses of the data of cable 2 ylelded a values of $110.64 \mathrm{ft} .(33.70 \mathrm{fo})$ and $41.99 \mathrm{ft} .(12.80 \mathrm{~m}$.$) for the x$ diraction In the swash zone and the $\gamma$ diraction in the aurf zone, respectively. 
since $X_{0}=125.0$ ft. $(38.2 \mathrm{~m}$.$) and Y_{0}=45.0 \mathrm{ft} \cdot(13.7 \mathrm{n.})$, etinates of $x_{p}$ and $x_{p}$ were $-14.4 \mathrm{ft} .(4.4 \mathrm{f.})$ and $-3.0 \mathrm{ft} .(0.9 \mathrm{~g}$.$) , respactively.$ The latter two values were entered in equation (4) to ylald adjusted values of mean displacements.

Estimates of Mean Partcle Veloctrles -.. In apply ing normal statiotics to the present set of tracer data, priaary attention vas given to an analysis of particle displacement becauge this variable alone possesses a component of randomess requiring statistical analyals. However, as prevlously meatloned (p. 14), the present sodel incorporates * continuous temo-parameter which is not randon. This parameter was used to compute the estimated meau particle velocity of the total tracer population once an estinate of the wean dioplacenent of particles in the population had been detemalned. Thus, wean velocity, $\vec{v}$, was obtained by dividing the final wan displacenent as computed using equation (3) by the average travel tha ( 30 minutes). The reaultat

Swash Zone -

$$
\begin{array}{ll}
\bar{s}_{w}(x)=13.22 \mathrm{ft} .(4.04 \mathrm{~m}) & \text { (south) } \\
\bar{v}(x)=0.44 \mathrm{ft} . / \mathrm{mith} .(0.22 \mathrm{~cm} . / \mathrm{sec} \text { ) } & \text { (south) }
\end{array}
$$

Surf Zone -

$$
\begin{array}{ll}
\bar{S}_{w}(Y)=11.13 \mathrm{ft} \cdot(3.40 \mathrm{m.}) & \text { (offshore) } \\
\bar{v}(Y)=0.37 \mathrm{ft} . / \mathrm{min} .(0.19 \mathrm{~cm} . / \mathrm{sec} .) & \text { (offshore) }
\end{array}
$$

An evaluation of the error associated with the mbove mean velocities ravealed three possible sources: 1) the pethod of computing the final means of particle diaplacement, $\bar{S}_{W}(X)$ and $\bar{S}_{W}(X) ;$ 2) the regresston estimates of $x_{p}$ and $X_{p}$ using $a$; 3 ) varlous field neasuranents in time and space. The first of these source containa the exrox of the accond two, and all thre enter Into the final extunate of the rean particle velocity. 
For the swash zone and the auf sone, the standard errors of the wean displacentents $\vec{S}_{\mathrm{W}}(X)$ and $\vec{S}_{\mathrm{W}}(Y)$ were found to be $0.31 \mathrm{~F} .(9.5 \mathrm{can})$ and $0.20 \mathrm{ft} .(6.1 \mathrm{~cm}$.$) , rapectively, or about 2.3$ percant for the former and 1.5 percent for the latter. At the 95 percent level of confidence, $\bar{S}_{W}(X)$ and $\bar{s}_{W}(Y)$ are expected to have fallen with1n \pm 0.61 ft. ( $\left.\pm 19 \mathrm{cn}.\right)$ and $\pm 0.39 \mathrm{ft} .( \pm 12 \mathrm{~cm}$.$) , respectivaly, of the true population means.$ These interval etimates, dividad by the man travel tise, w11 suffice for the wean particle velocities as we11. provided that the avarage travel clue (30 minutes) was datermined exactly. Thlo was probably not the case, as all fleld samples could not be collected simultaneously at cheir destgnated recovery tiwes; neverthelace, all sampling was done in ordar, so that a given station was visited once evary 10 minutes, aliowing several seconds of exror. Ansualng that the errors are not cumulative from one 2 ampling perlod to the next, average travel tome was probably accurate to whthin \pm 1 minute. Accordingly, the varlation due to thac of sampling may have caused an error of approximately $\pm 0.02 \mathrm{ft} . / \mathrm{min}$. ( $10.01 \mathrm{ca} . / \mathrm{sec}$.$) whleh is additive to both relocity$ estimates. The final estimates axe then

$$
\begin{aligned}
& \bar{v}(\mathrm{X})=0.44 \pm 0.04 \mathrm{ft.} / \mathrm{min} .(0.22 \pm 0.01 \mathrm{csa} . / \mathrm{sec} .) \\
& \bar{v}(\mathrm{Y})=0.37 \pm 0.03 \mathrm{ft} . / \mathrm{min} .(0.19 \pm 0.02 \mathrm{~cm} . / \mathrm{sec} .)
\end{aligned}
$$

\section{Discueston of geeulte}

\section{Comapar1son of Particle Movement and Eavironmental Rectore - A}

comparison was made regarding what to known or theorized about the wovement of bach sand in the nearahor region. and the results of the present expexinatent. Thio was not an attempt to extrapolate the data obtalned in any way, as it is not latended that these results should take the form of a prediction of avarage conditions in the vicinity of Virginia Bacts. 
King (1959, Dp. 125-127) gives an accout of tank axpexinents In which daep watar vave steepness (helght-tomlength ratio) was ralated

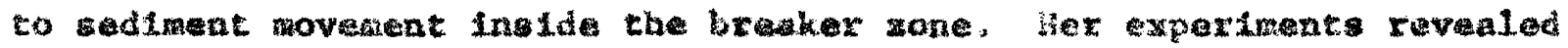
a critical deep water wave ateepness $\left(\mathrm{H}_{\mathrm{o}} / \mathrm{L}_{0}\right)$ of 0.012 whloh, when axceded, rasulted in gemard movement of bottom therial, the anount

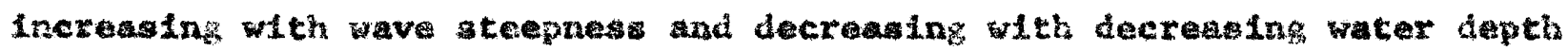
In shoreward direction. It was further shown tht an onshore whd anakedly incraased the rate of seaward transport. Saville (1950) conducted tah experinents which showed that longshore transport of sand was Ifniced to wave staepnese. For breaking trave anglea of 10

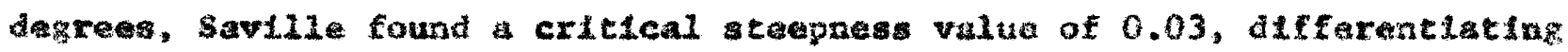
steegwav transport in the breaker zone as opposed to frat-wave transport.

In tha pandelton fld experiments, deap water wave canneas was

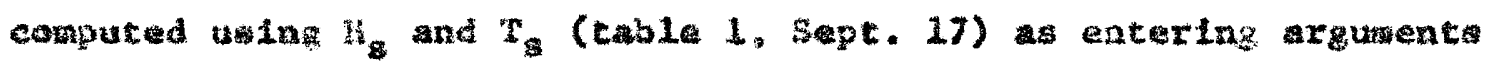
In appropriate graphe and tablas foud in wiesel (1964) for progress Ive, Inear waves fit boch deep and ahallow watex. A value of 0.0092 was obtalned for the deop watar wave stapness at the thas and plece of the experimenc. This stapness value, based on presant knowledge, is con-

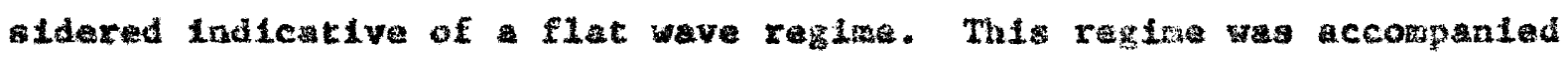

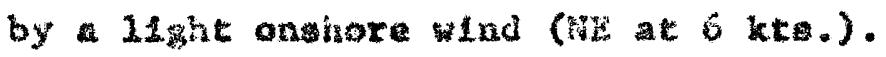

By way of comparison wht saville's restits, it foy be noted that longshore transport of saad was evidenced In the wash zone durfng the present exprextont, as would be expected for a flat wave regine.

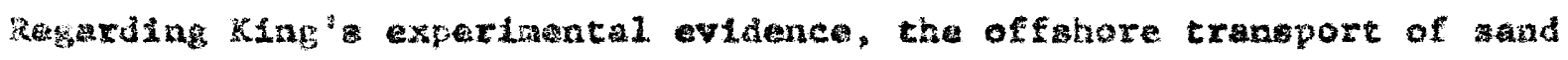
In the surf gone of the Pendelton gransect was not in the direction expeted, based on Elat wave condithone. however, discreparel have been noted betwexn crictal sceeprass values for field and laboratory wavas, Whth some evidence showira that fleld values may bo lower by

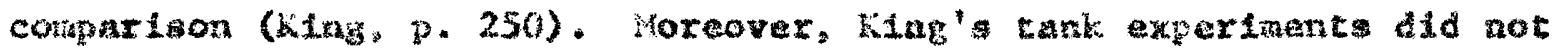


speciflcally recogntze a surf zono - swash zone delineation shoreward of the breaker zone as is often observed in the fleld.

Ifamada's (1951, p1. 93-94) work ou model beachat specifically recogulad a surf zone shoravard of the breaker zone, and for opiling type breakers, he observed a vell-developed return flow (seaward) along the botton in the surf zone. In addition, field measuronents in the surf zone by Shepard and Inmen (1950) and Schlffuan (1965) have revealed the existence of a layered flow with a persistant seaward componerit along the bottor. In theory, net shorewnrd transport of aurface water is balanced by seaward bottom flow tn a system of cicculation about the horizontal axis, whereas intermittent "rlp" currenta generated by longshore water transport are part of a separate cleculation about a vertical axts (hamada, p. 94). The botcon flow, measured at consistently better than $1.2 \mathrm{Et} . / \mathrm{sec}$. by Schiffuan, probably best explalns the ceatara particie displacenent, $\bar{S}_{w}(Y)$, of this study.

A value of $q_{f}$ was computed $(p, 24)$ from the environmental data which corresponded to the nat volume change that occurred in ant length of the foreshore, from one high tide to the next, prior to the tracer axperiment on September 17. Th1s result $1 \mathrm{~s}$ given in table 1. Using the basic graphic data (beach elevations plotted along the foreshore Wlath normal to the shoreline), the net value of $\eta_{f}$ was separated into 1ts positive (depositional) and negative (erosional) conponents and the Seneral location of these components noted in relation to the grid system of the tracer experiment. It was found that almost all of the exosional component of $Q_{f}\left(4.02 \mathrm{yd} \cdot{ }^{3}, 1.11 \mathrm{~m} .{ }^{3}\right)$ was diotributed along a $40 \mathrm{ft}$. section at the seaward edge of the surf zone and beyond. Thus, active erosion in the general area of tracer release was conconttant with sand 
accumiation In the outer surf zoce, toward which tracer partlctes steadily moved. Algo, there was iftele net change over most of the

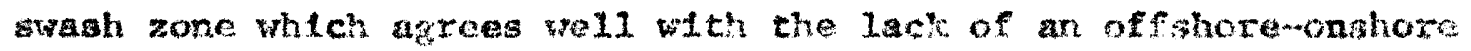
component of tracer isplacenent there $(\mathrm{flg}, 16)$. These comparisons are lmortant, iragnuch as they demonetrate il unique type of information obtainable through the uge of tracers: 1.e. tracers can give the observer an almose tnstantaneous picture of the trends in sedinent moverient as opposed to a much slowex, t1remavaraged result obtained through proflle measurements. This fact allows one to ut1118e tracers in preiluinary investigations of a ste chosen for more extensive study, as well as to correlate tand novement wh environemtal factors, meabured inultaneous $1 y$, in a given txacer experiment.

\section{Comparison of Mean Particle Veloctey with Prsected Particle}

Veloctty - There are several examples in the 11terature in which estimates of longhore particle velocity have been made using and tracers. These estinates are compared with $\vec{v}(x)$ values obtained in this tudy, Mowever, no atjuates have been made, lesofar as the author 18 aware, of the particle veloctties between dyramlc zones in the onshoreoffshore direction. Ingle (1966) observad that sode of his tracers moved fron the inshore to the offshore reglons under the influence of $x f_{p}$ currents (a fact ade obvious by the turbld appearance of the seawardwoving "heads" of these currents in otherwise clear water), but did not attempt to quantify this movent. others (Zelgler, et al.. 1959; Bowen and Inman, 1966) have discussed in general way the budgetary aspects of onshore-affshore sand depos1ts. Probably longshore sedineat transport has recelved more attention because, compared to onshore-offshore transport, it is easter to measure, it continuous gyer longar distances, and is trportant to the design of breakaraner 
and groins. This is perhaps unfortunate, because my lavestigators tend to assume that longshore sediment trangport occurs in a closed, two-way system wh no loss of tracer material. efther seaward or at depth. That such an asauption is unlikely 1s beat released in certain cases of severe shoreline exosion (racession) where longahore currents are practically zero. At any rate, there are no means of comparing, $\bar{v}(Y)$ at present.

The numbers of estinates of longshore particle velocity are few to date, some of these being in the form of pllot experinents mentioned in preliminary progress reports (e.g., Iman, 1967). Even Inal reports, however, point out that wide range of estimates of velocity values are possible. Slebold (1963) reported average particle velocities ranging from $0.5 \mathrm{ft} . / \mathrm{min}$. to $5.5 \mathrm{ft} . / \mathrm{fln}$. for $10 \mathrm{w}$-energy waves on the delc coast. Ingle (1966) reported the results for a berles of experiments on the Calffornio coast under somewhat greater wave-energy conditions, obtaining particle velocitles of from 3.6 to $22.7 \mathrm{ft} . /$ min. (with an average of $10.0 \mathrm{ft.} / \mathrm{mint}$ ).

It appears tron these exmples that the value for $\bar{v}(\mathrm{X})$ of $0.44 \mathrm{ft} . / \mathrm{min}$. In the present experimant represents a rather minimal particle velocity. However in view of the environmental data (table 1), thls result does not appear unreasonable. For example, the angle of wave approach was only 4 degrees, and thean breaker helght was less than 2 ft. Such a combination of factors would cend to produce a low component of energy parallel to the shoreline in the direction of particle moveraent. In addition, a low value of the man foreshore slope (about 2 deg., $\bar{n}$, table 1) and a farly long wave perlod (about 6 aec., $T_{8}$, table 1) ware expected to have tatnimfzed this 
coraponent. The longahore component of wave-energy proved to be the only dymate varlable that ingle could corralate wh his range of tracar frain veloctites, and, 14 one can judge by his reaulto (pp. 151-152), vary 1itrle corralation exista between grain veloc1ties and other semingly tmortant variables such es longshore current velocity. Ingle used a value mich he termed the relative alongshore energy, computed

$$
\overline{\mathrm{W}}_{\mathrm{b}}^{2}(\cos \overline{\mathrm{a}} \sin \mathrm{a})
$$

to obtain his best linear corralation $(x-0.35)$ with average tracer srain velocity, derting the ragression equation

$$
Y=5.012+3.832 \%
$$

ware $X$ and $x$ are respectively the energy and velocity vartables. One notes that the intercept of this line Indlcates grain velocity of slightly more than $5 \mathrm{tt} . / \mathrm{min}$. For zero alongshore wave energy. This rate of wovenent is then an approwimation of the error involved In Ingle's arem-integration or deplation method of obtatning mean tracer veloctefea (pp. 5-6), inamuch sovarsal in direction of aloaghhore wave energy would demand that the corresponding reversal in partlele veloctty pass through zero. Purt of this error may be die to the lack of any means of adjuting velocity astrates for nonxepreaentacive luitial grain aotion $\left(x_{p}\right.$ and $y_{p}$ in this cudy). Anothar reason for the above error in the depletion nethod of tracer analysis y 11 in the fact that no account was taken of possible tracer dilution with some lose of material at depth. Such dilution was found to be a linfting factor as regards running tim of flume expertments with radloactive and trmcers (Crickmore and Lean, 1962a). Figure 18 18 diagram showing how this ma occur. Boon (1967) comducted a flald study of tracer distribution patterrs 
on a carbonate beach at several depth intervals within 39 sand cores and observed that signiflcant amounts of tracer occurred localiy in some samples as much as $10.0 \mathrm{~cm}$. (4.0 in.) below the surface. Using the area-integration method, such quantitias of tracer would be erroneous1y credited with having left the study area through surface travel, thereby causing a blased estimate of particle veloctty. F1gures 14 and 15 show graphically that, although an overall dintuntion of particle frequency did occur with time in the present experinent, the distribution of particle displacementa remained well defined for those tracers remaining at or near the surface within the active zone of transport (mob1le layer). Conversely, any tracer particles falling below the zone of actlve transport were without means of appearing in the core samplea, and therefore could not affect horizontal particle velocity estinates $\bar{v}(X)$ and $\bar{v}(Y)$.

Using the tIme-integration method, Yasso (1965) obtalned grain velocity estimates in the foreshore (swash) zone of a beach at Sandy Hook, New Jersey. For a 5.3 second breaker perlod having a maximum height of $0.73 \mathrm{~m} .(2.4 \mathrm{ft}$.$) and an angle of approach of$ approximately 5 degrees, he found maximum longshore particle velocities of between $2.0 \mathrm{~cm} . / \mathrm{sec} .(3.9 \mathrm{ft} . / \mathrm{man}$.$) and 2.8 \mathrm{cs} . / \mathrm{sec} .(5.5$ ft./min.) as indicated by arrival times of the first few grains at a known distance from the point of release. However, the average particle velocity as denoted by the arrival time of the main body of tracer was only $1.2 \mathrm{~cm} . / \mathrm{sec} .(2.4 \mathrm{ft} . / \mathrm{min}$.$) , The latter value is$ still higher than the mean particle veloc1ty $(0.22 \mathrm{cin} . / \mathrm{sec}, 0.44$ ft./min.) obtained at the Pendelton Transect, even though wave conditions were very nearly the same and bottom slopes in the swash zone were almost ldentical (about 6.5 deg.) for both areas. Figure 
19 is a graph taicen from Yasso's report which gives the frequencytime data of his tracars for a txavel distance of $30.5 \mathrm{~m}$. (100 ft.). An lwadiate siandartty way be seen between this graph and figures 14 and 15 , the min difference beins in the choice of the variable, 1.e. time as opposed to distance. In regard to sampling procedures, however, Yasso sampled only 3.0 . (9.8 ft.) section perpendicular to the shoreline beginning at the backwash $11 \mathrm{mit}$ and moving ohoreward. One can question, therefore, whether the movement in the remalning portion of the swash zone, whose total widh was not given, was of slmilar magnitude. It may also be noted that the arrival time of the maxtmum tracer concentration in figure 19 (Yasso atated that It whs $42.3 \mathrm{~min}$.) 16 anlque value which must be accepted as is; 1.e. no comparisons are posstble with time and thus no initial impulse displacements $\left(X_{p}\right.$ and $X_{p}$ in this study) are taken into account. Difficult as 1 t may be to draw conclusions from single experiments, the results of the present study suggest that previous estimates of the longshore particle velocity on ocean beaches may have been too high or else not quite representative of the overall particle movement. This is not to say that under conditions of higher alongshore energy a repeat of the procedures used here would not yleld much higher particle velocitles. As a matter of tntuitive judgement, there should be 1 inimal particle velocities associated with mintmal energy conditions.

\section{Estimation of Mean Rate of Sand Transport - In order to}

obtai an estimsta of the rate of and transport in a given area, both average particle velocity expressed as a vector, and the crosagection-1 area of active transport normal to chis vector must be known. Inasmuch as the direction and magnitude of longshore particle veloci- 
ty is known, along with the with of the crosg-sectonal area (width of the stam zone), there remains only the vertical thiclness of the mobile layer to be deterained. Unfortunately, this lis one of the wost Qlustve unknowas in the field of beach research, and at the same time one of the most important; by having only glifht differences in the thickness of the moblle layer, one can derive vastly different values of longshore transport.

Ingle's (1966) estimates of noblle bed thicknesses varted betuten 0.05 and $0.10 \mathrm{in}$. on the average (p. 6); Deing dertved as a function of his average tracer velocltles, they are therefore subject to the same errors may be assoctated with those velocitios. At any rate, cextain facts suggeat that the eatrates of thlcknesses hust be wore than a few graln diameters. Wherever tracer gratna are entrained in ripples on the bottom, as they often are on beaches, it

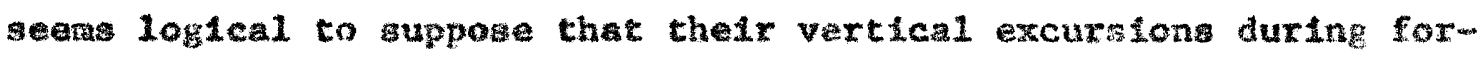
Faxd novenent would be at leat as much as the anplitude of the ripple wave form (which usually axceeds 0.10 in.). In addition, fild expertinents deh dyed sand In Fingland (KIns, 1959) have ahown that the depth of wave-Induced bottoin disturbance in ch. 13 about extual to the breaker helght in feet. In the case of the gendelton Transect, a disturbed layer $1.8 \mathrm{~cm}$. (0.71 in.) deep could then be expacted. If the moblle layer can be assuned constant at wost points Inside the breaker zone, then thickness nay be directly computed using the data of the present expertment. Thes was done by furthax assuming that the accretional $(+)$ portion of $q_{f}$ at the outer lint of the surf zone (f1g. 3) was the result of offshore transport. Whe later is a rasonable assumption since 11ttle longhore transport wav evidenced in this zone and the adfacant breaker zone forus a 
abstantia1 barrier agalnst onshore transport (Hanada, 1951, p. 96). Using the equation

$$
q_{f}(Y)=\bar{v}(X) \cdot A \cdot B
$$

where $\eta_{f}(Y)=$ rate of sand accretion $\left(1.45 \mathrm{yd} .^{3}\right.$ in 13 hours or 0.054 ft. $\left.{ }^{3} / \mathrm{min}.\right), \vec{v}(\mathrm{X})$ wean particle velocity offahore $(0.37 \mathrm{ft} . \mathrm{min}$.$) ,$ and $A=$ unit width used to obtain $\eta_{f}(1.0$ or $3.28 \mathrm{ft})$, 3 the mobile layer thickness was found to be $0.50 \mathrm{ln}$.. This value, by Lortultous coincidence, was exactly the thickness removed from the cop of each core for tracer counting. In 11ke manner, the rate of longhhore wand transport, $Q_{f}(x)$, was computed using equation (s) with $B=0.50 \mathrm{in.} A=45.0 \mathrm{ft}$. (width of the swash zone), and $\bar{v}(\bar{x})=$ $0.44 \mathrm{ft} . / \mathrm{min}$. $1 \mathrm{dving}$ an estimate of $0.82 \mathrm{ft} .{ }^{3} / \mathrm{min} .\left(440 \mathrm{yd} .{ }^{3} / \mathrm{day}\right)$. This value is within the broad range of sand transport rates obtained by coastal engineers (Fairchild, 1966, p. 33) ustag profile data. A more exact comparison cannot be made owing to the lack of suffictent prectsion in large-scale beach surveying nethods.

Recomendations for Future studies - The conclustons of the present wtudy are che product of a Ingle fleld experinent. It is apparent, therefore, that more work is required to conflrm and enlarge upon the results. Certain basic assumptons about the novenent of sand on an ocean beach were examined in the $11 \mathrm{ght}$ of previous studies and, 1f nothIns wore, the data and methods given in this paper point to the need for a better understanding and resolution of the problems involved.

Although there are many ways to collect samples of a population of tracers released on a beach, all fall within two basic categortes; one can elther collect surface gralne or take samples inciuding subsurface grains. There is a definte advantage to sampling in depth 
as the results of several studies, Including this one, have shom. However, it met be recognized that the number of cors or hand-graba that can be obtalned is 1inited by the short collection periods required if the total sample is to be nearly synchronous. Consequently, If only few of the cores or hand grabs taken should fall outside the fleld distribution of tracers, a serious shortage of daca could result. On the othex hand, tha graaed-card cechnique used by many lavestigators collects only burface gralna, but these can be obtalnat at aster rate over wider area. In view of the relative advantages and disadvantages of both surface and absurface lamples, one ray wish to wake a fnal cholce based on the precific requirements of the study. For axample, where tracer grain wotlon in only one direction is anticlpeted, such as in an fniet or an estuaxy, one may wht to we long atrips of greased-fila. These can be unrolled along the bottom to plck up surface actarial, thereby regulting in fully continuous record of particle displacements in the chosen direction at any iven time. In sum, more fitid experiwents are recownended to evaluate all of the methode of collection which are now possibla.

Along with tmprovenents in the design of sampling techniques, there is a need for st111 greater emphasis on finding the best statist1cal techniques for axcquataly describing various typeg of grain potion. The present study ut111zed a smle stochaste-process model incorporating noraal statistics. Beach sand wovenent in this nodel was vism walized as a sertes of partical diaplacements hatas component of randomess. More advanced stochast1c-process modals such as those involving farkov chatns (p. 12) way become femsible wh further study. To employ Markov mode1, one must flad a way of locating the same tracer particle again and agaln over suffectent interval of tint vichout 
removing 1t from the transpote system. Having accomplished this, the probability of a given magnitude of paxticle Alsplacement occurring during one Interval of time is then based on the displacement magnitude observed during one or more preceding Intervals of tine. Using Markov chains of sufficient length, one night ultinately be able to describe not only linear but periodic particle movenent. The resder interested In coaputer programs written for related experiments incorporating the Markov model is referred to Krumbein (1967). 


\section{SUMMARY}

The present study at the Pendelton Transect in Virginla employed tracer technique that is new in several reapects. Because beach phenomena exhlbit considerable vartation attributable to complex variety of Interacting physlcal mechanisas, a type of stochasticprocess nodel was envisioned as having acted through the vartable of particle diaplacement. The otudy was then deslgned to sample an Infinite number of randon particle displacenents, $X(t)$, where $t$ is time. Each sample, then, consisted of a large number of diaplacenents denoted by tracer grains recovered over fixed horizontal grid system after a specific tiae. The number of items in the sample, or sample size, was therefore equal to the total number of grains recovered at any given the. Actual recovery of gralns at any polnt was accomplished in subsamples of the beach materdal obtained in plastic corlng tubes and by hand, care being taken to retrieve the top $0.5 \mathrm{in}$. of sand in a constant voleme for counting purposes.

The resultant tracer data of the Pendelton experiaent were arranged in row-colum watrix for certain prelininary tests. These cests consisted of chl-square homogenlety test and a Fourfer trend surface analysis which revealed a separation of the date based on two dynantc beach zones, the awash zone and the surf zone. Using these two sets of data, bivarlate normal statistics were applied to displacements in the alongshore $(X)$ and onshore-offshore $(X)$ directIons. The resultant nean displacements $(\bar{X}, \bar{Y})$ were converted to mean velocities $[\bar{v}(X), \bar{v}(Y)]$ after weighting procedure was carried out and an average travel time was computed. It was found that a 
we11 developed southerly longthore grain velocity was confined to the owash zone on the dny in guestion, whlle offehore motion prevalled in the surf zone.

In addition to the grain velocity estinates finaliy computed (0.44 ft./min. south In the swash zone and $0.37 \mathrm{ft./min.} \mathrm{Offshore} \mathrm{in}$ the surf zone), vilue repreeenting the thickness of the roblle layer of and was determined usting $\bar{v}(Y)$ offshore and beach profile data obtalned during the study. The reaultant thickness was about 0.50 In. (1.3 c...).

The chickness of the mobile layer, along with the width of the swakh zone and the longshore estimate of grain velocity, was used to compute an Independent estante of the rate of longhore sand transport. Thus, using value of $0.50 \mathrm{in}$. for the mobile layer thickness, a value of $45 \mathrm{ft}$. for the width of avash zone (f1g. 3). and the average longmore particle velocity computed as $0.44 \mathrm{ft.} / \mathrm{faln}$., a transport value of $440 \mathrm{yd} .{ }^{3} / \mathrm{day}$ (336 . $3 / \mathrm{day}$ ) was obta1ned. 
Armora 
Pigure 1. Location map for area of etudy (after harrioon, eㅗ 스., 1965). 


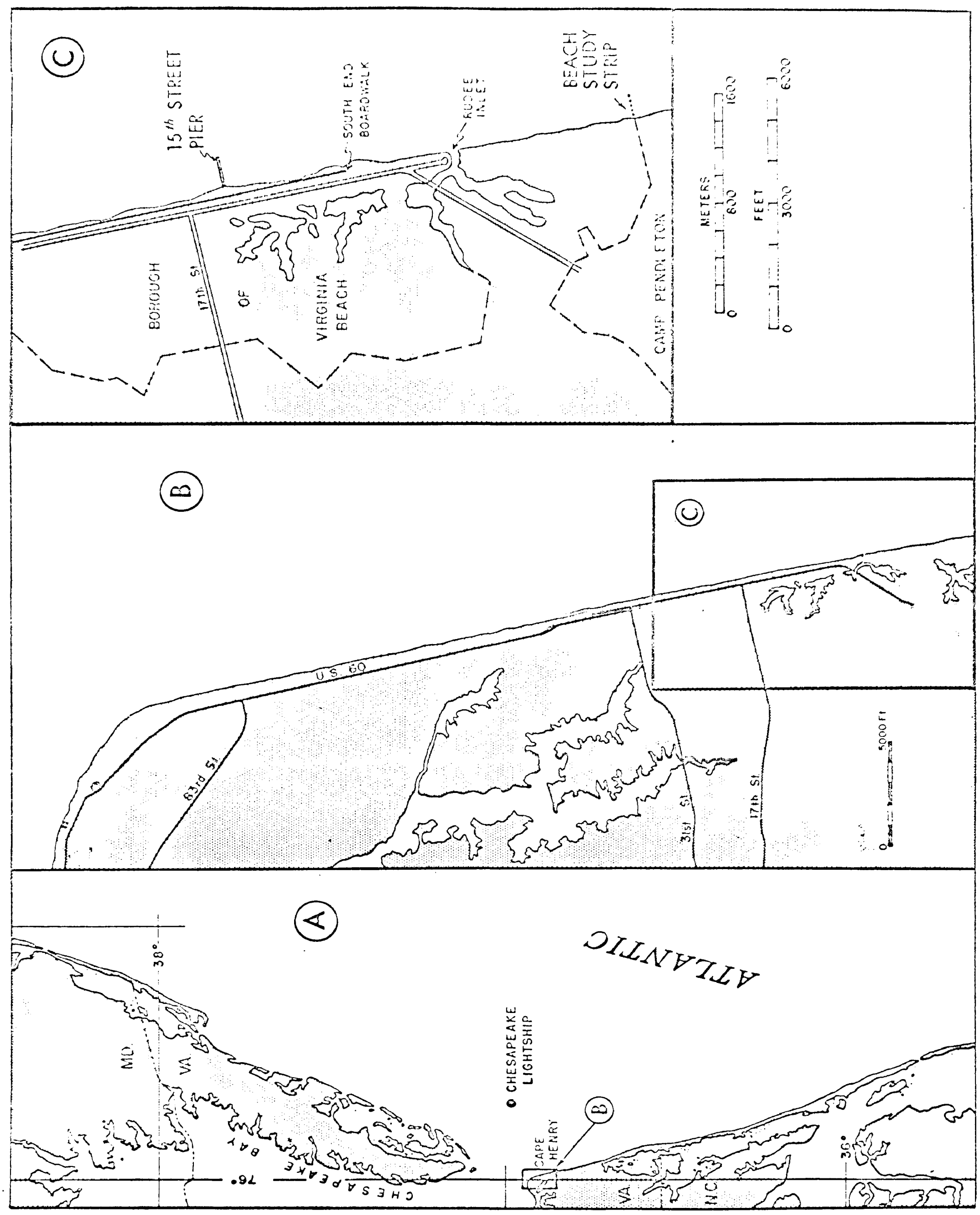


Figure 2. Characterietice of beaches (after Ingle, 1966). A: Ceneral features and terminology. B: Deafgnation of dyounte zones and 1deallzed water eireulatory pattarns. 

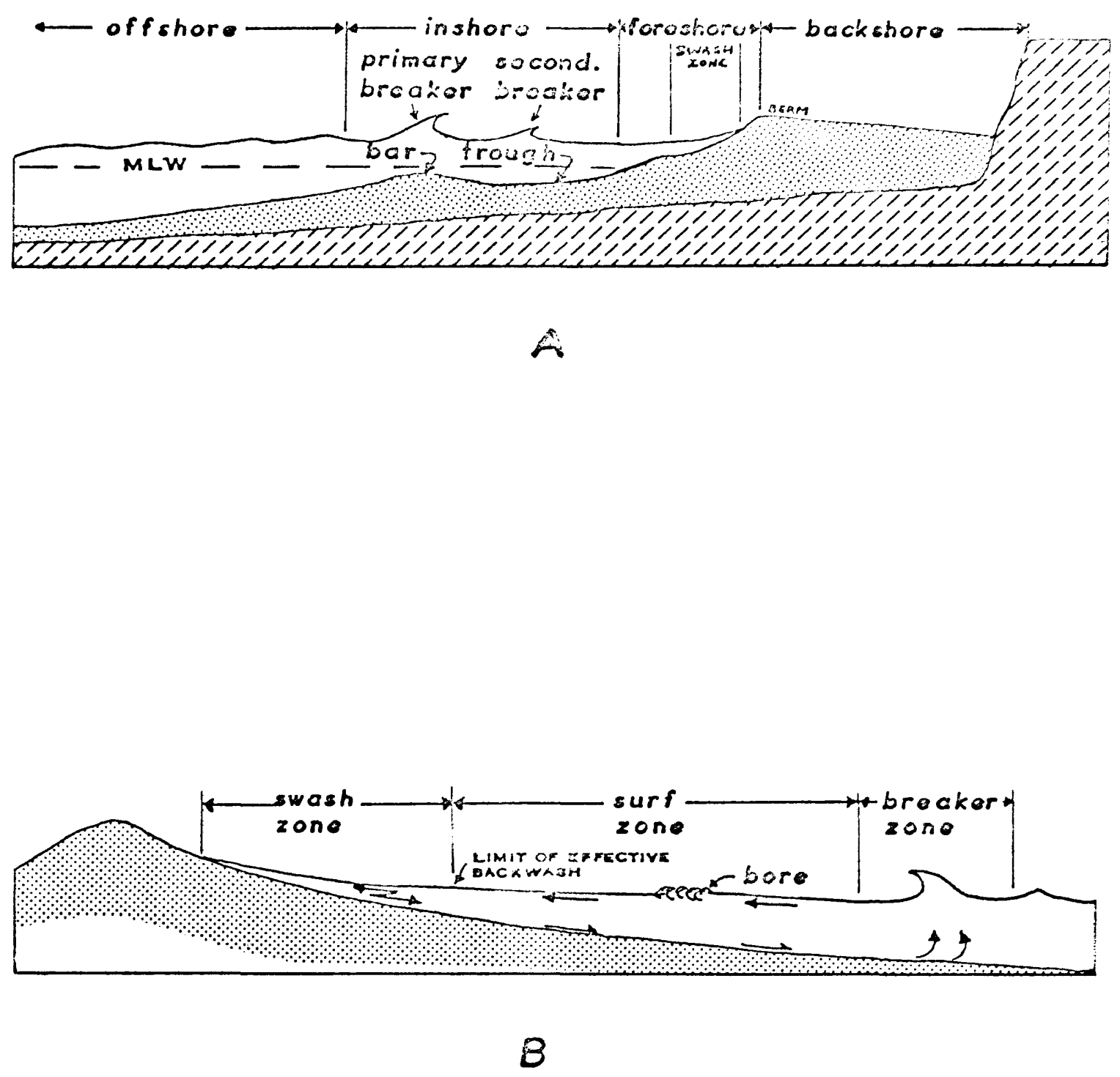
Figure 3. Kap showing botcom topography and posttion of ourf and swash sones, Pandelton Transect, Sept. 17, 1100 hrs. (datua: axbierary). 


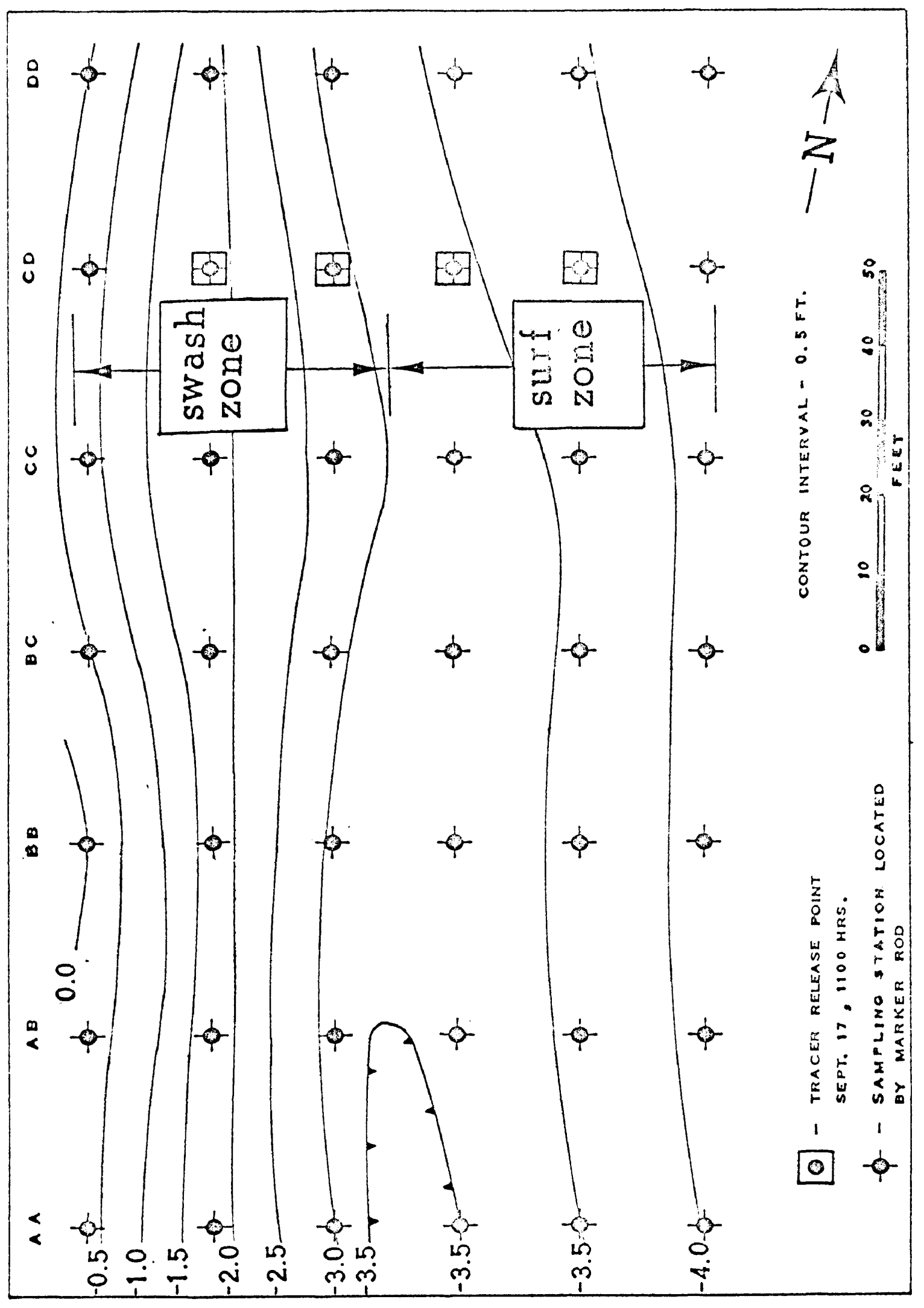


Mgure 4. Row-colum grid shewing polnte of traeer partiele release and eand anple recovery. 


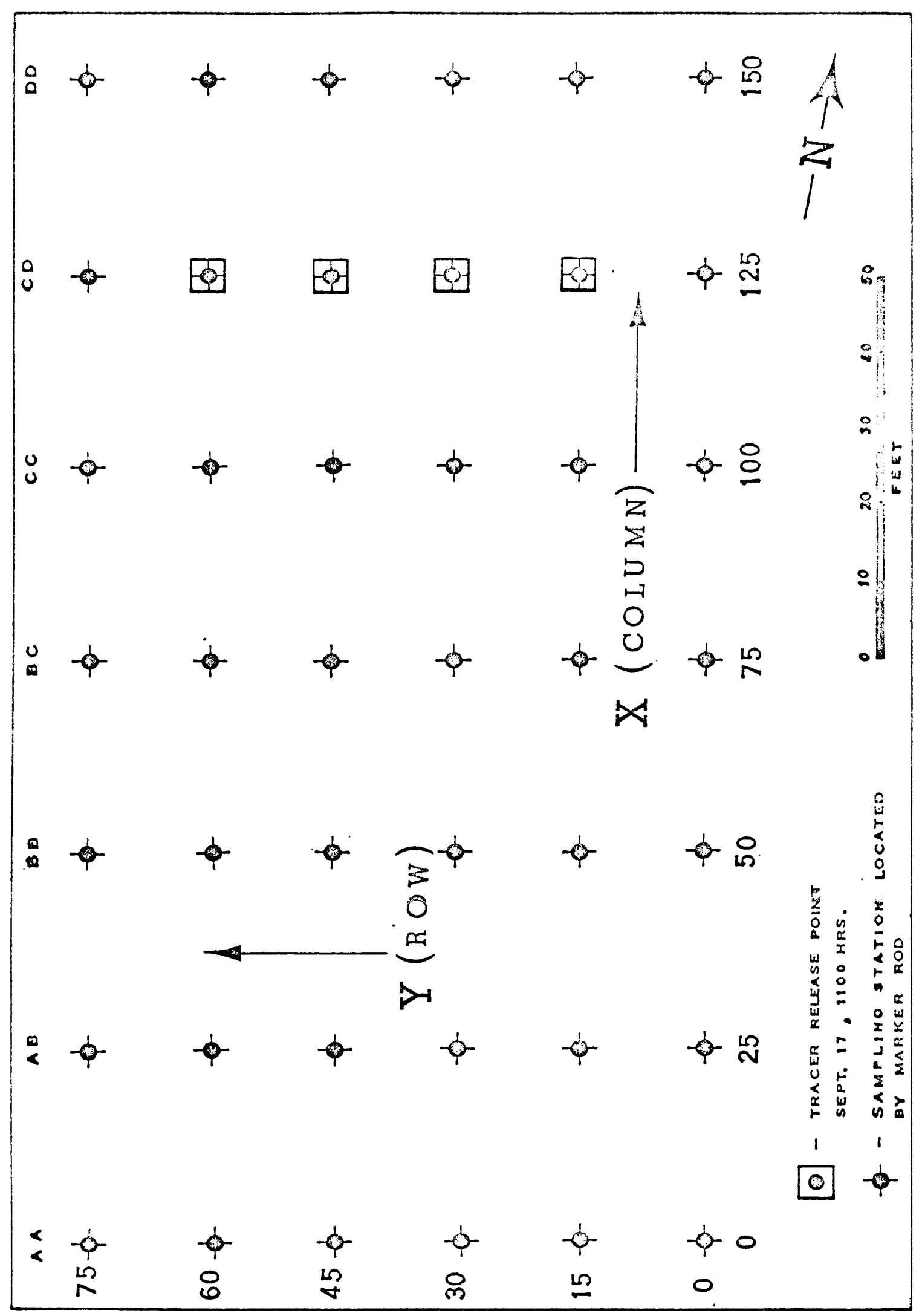


Flgure 5. Device used to obtaln sand cores at Pandelton Treasect. 


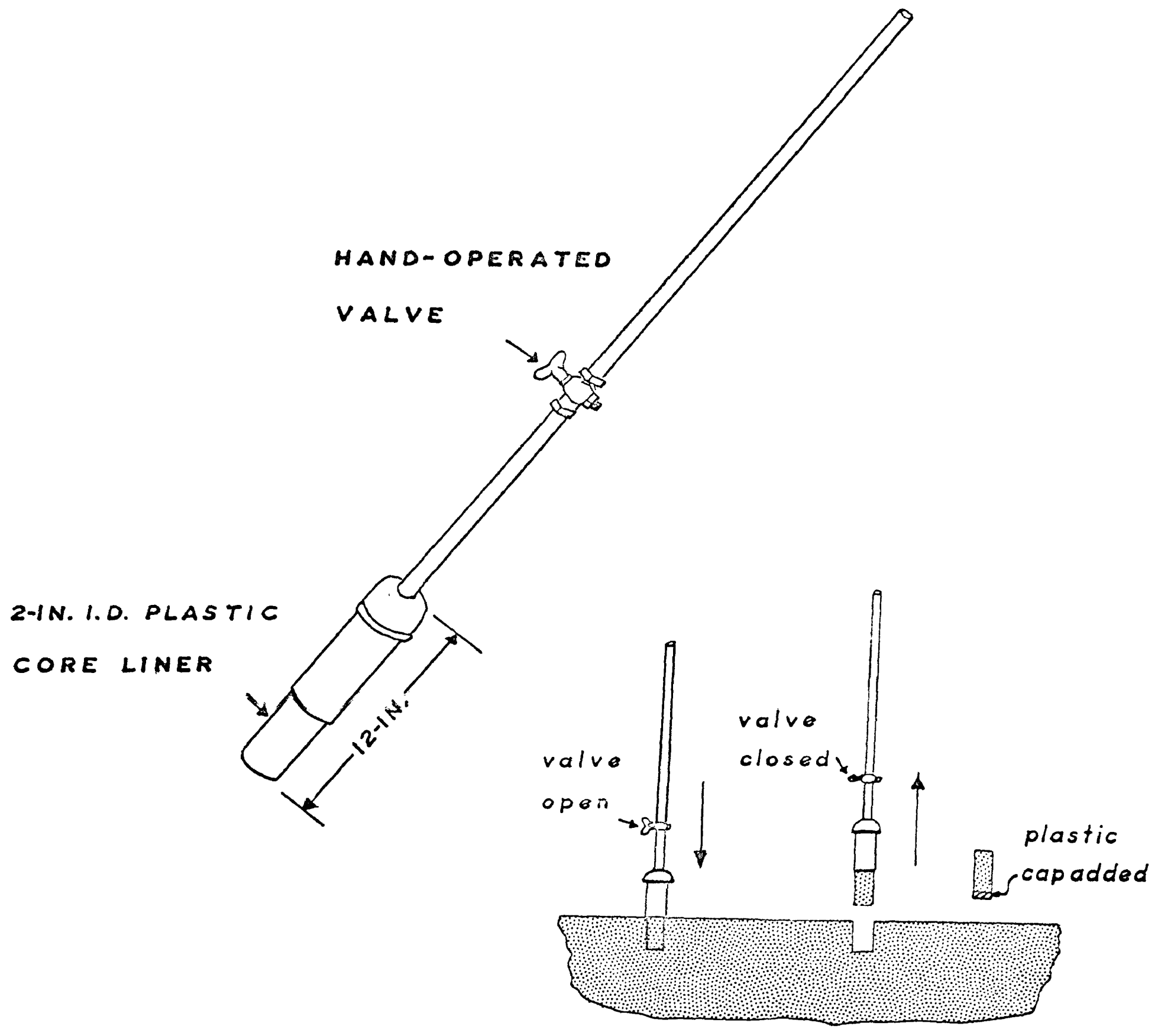




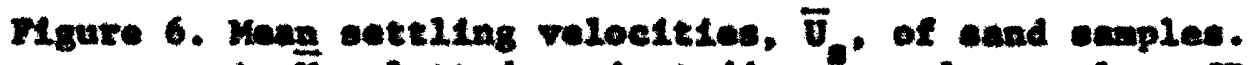

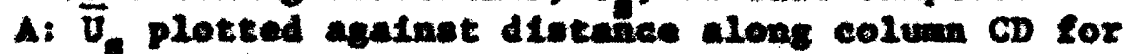
Sopt. 16, 2200 hre.. Sept. 17, 1100 hre., and for tracer material (i. -4.15 an./ece.). B: Hap of tield distribution of $\bar{v}_{s}$, sept. 17,1100 hre.. 


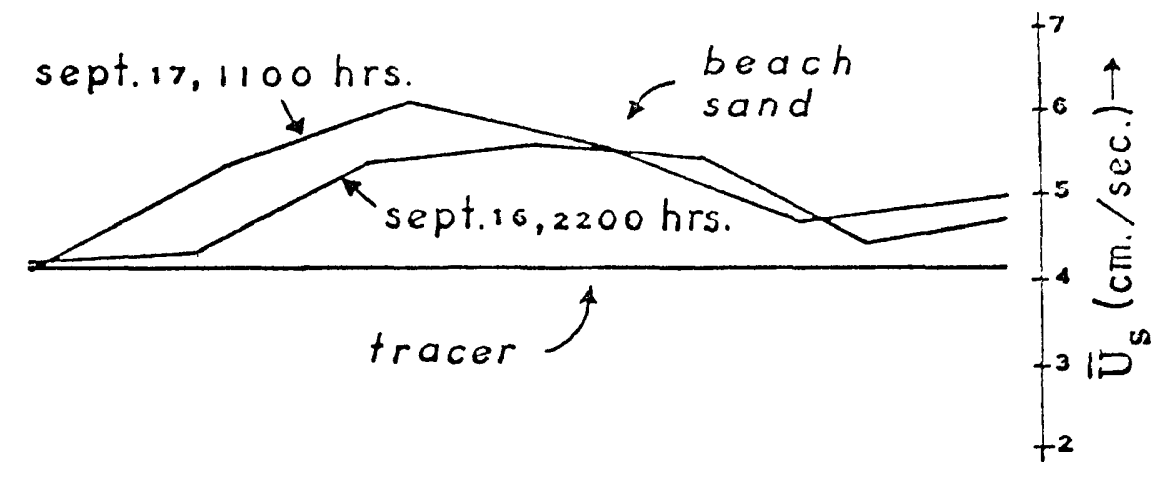

Co

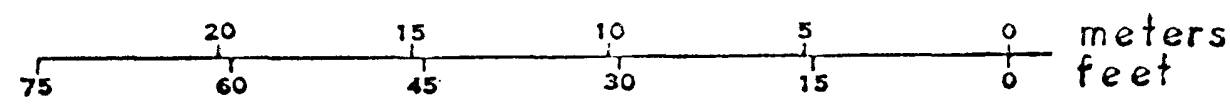

A

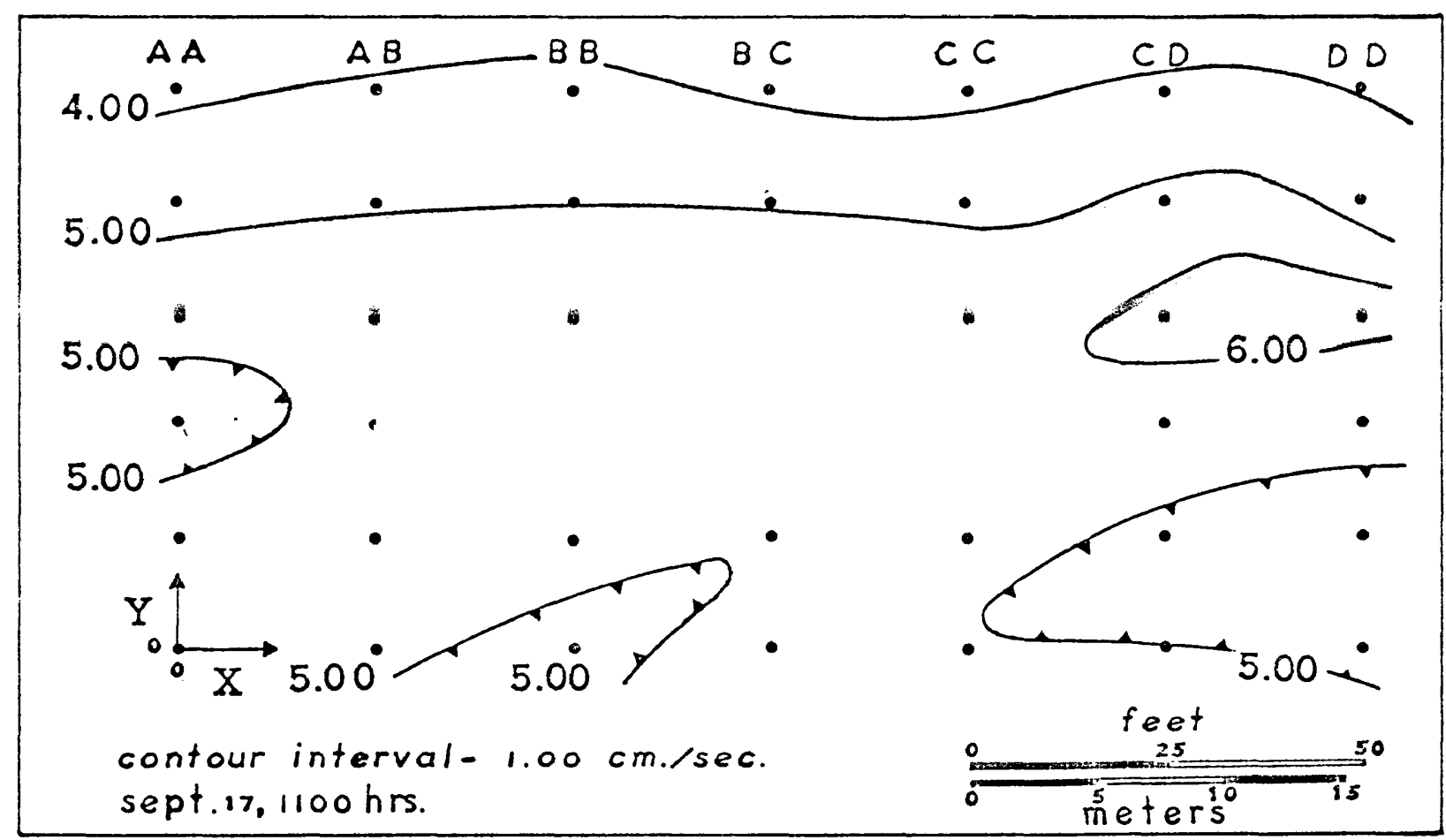


Figure 7. Schmattc eection of beach hoving method of deternining $Q_{\text {f }}$ for two auccessive high tides, 16 Sept., $2206 \mathrm{hra}$. and 17 sept., $1100 \mathrm{hrs}$. (modifled from Harribon, et al., 1968). (A) is the position of top of swash on successive high vater stands and (B) is the Innermost position of Invhore margin of breaker zone on succeselve high water stands. 


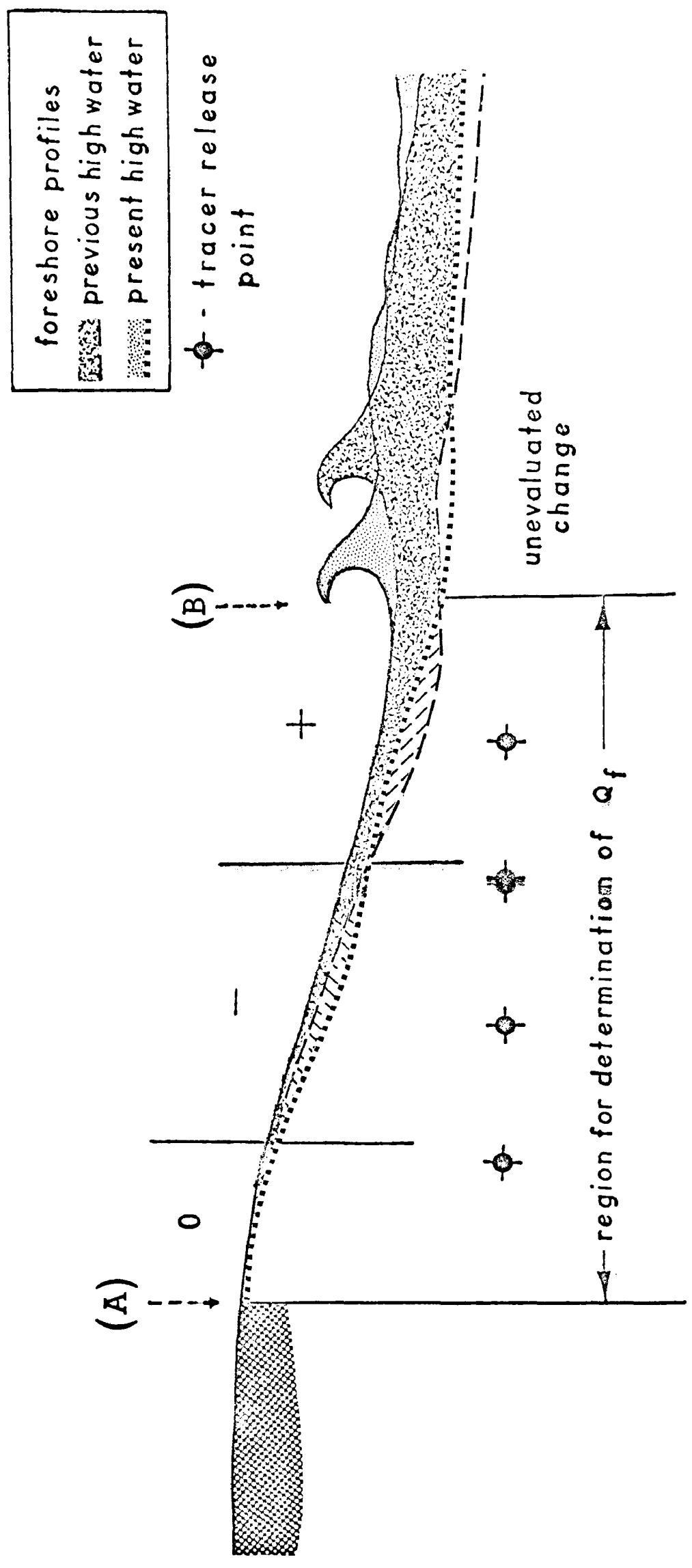


Migure 8. Fourler tread continuou eyrbol tap of tracer partiele concentration $10 \mathrm{~m} 1 \mathrm{n}$. after relense (contours added by the author). 


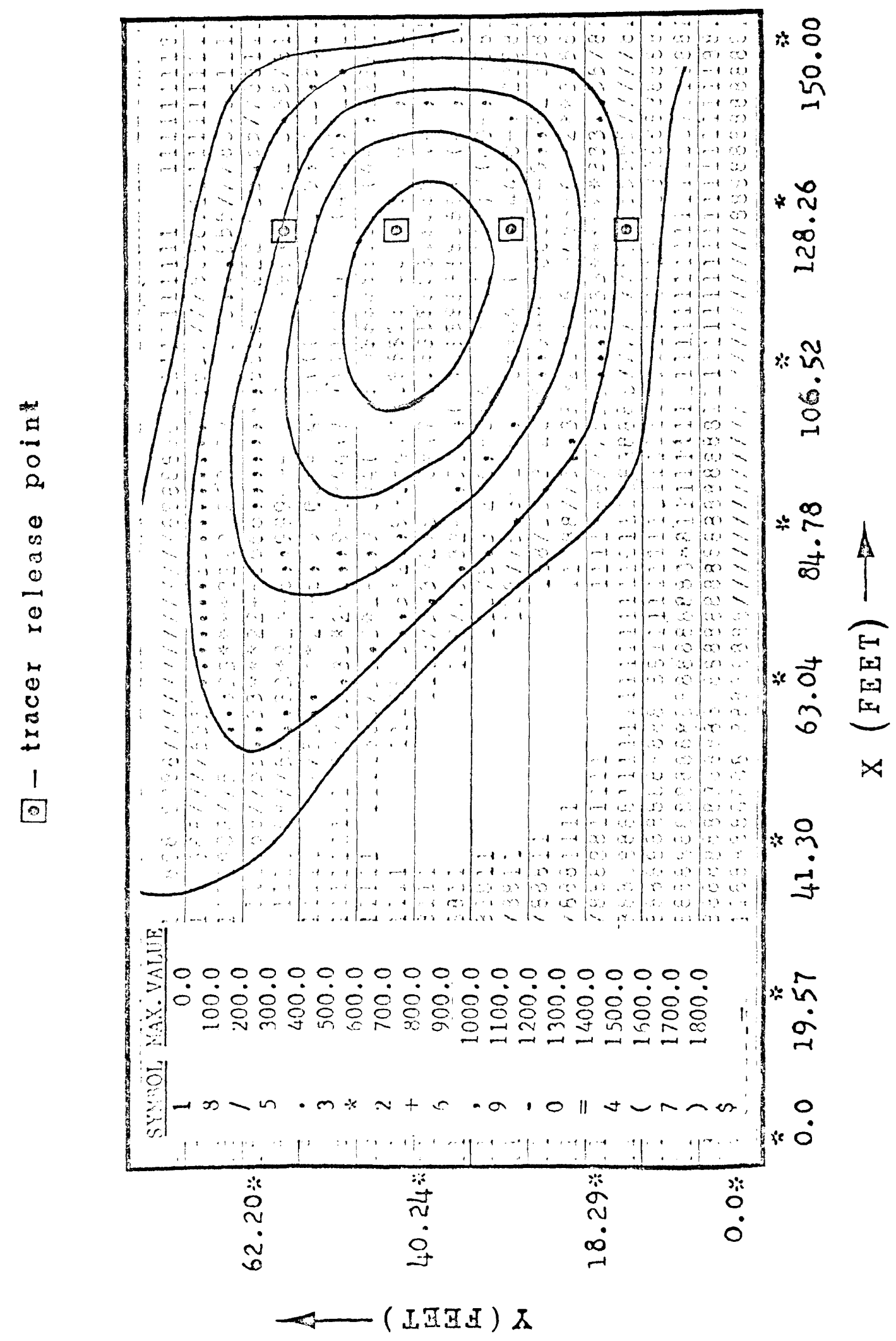


Figure 9. Fourter trend continuows symbol map of tracer particle concentration $20 \mathrm{~min}$. after release (eontours added by the author). 


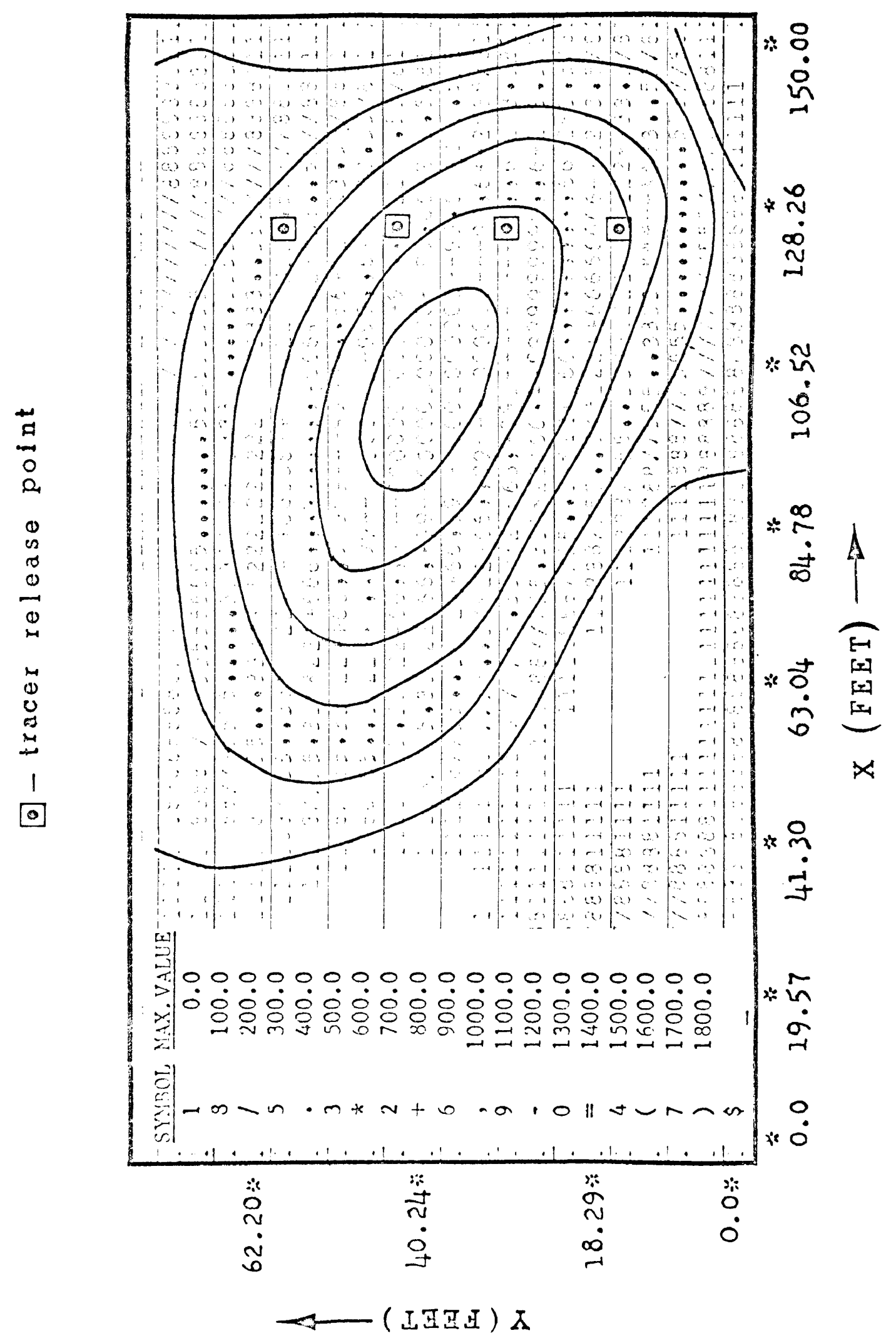


Figure 10. Fourler trend continuous aymbol map of tracer particle concentration $30 \mathrm{~min}$, after release

(conteur: added by the author). 


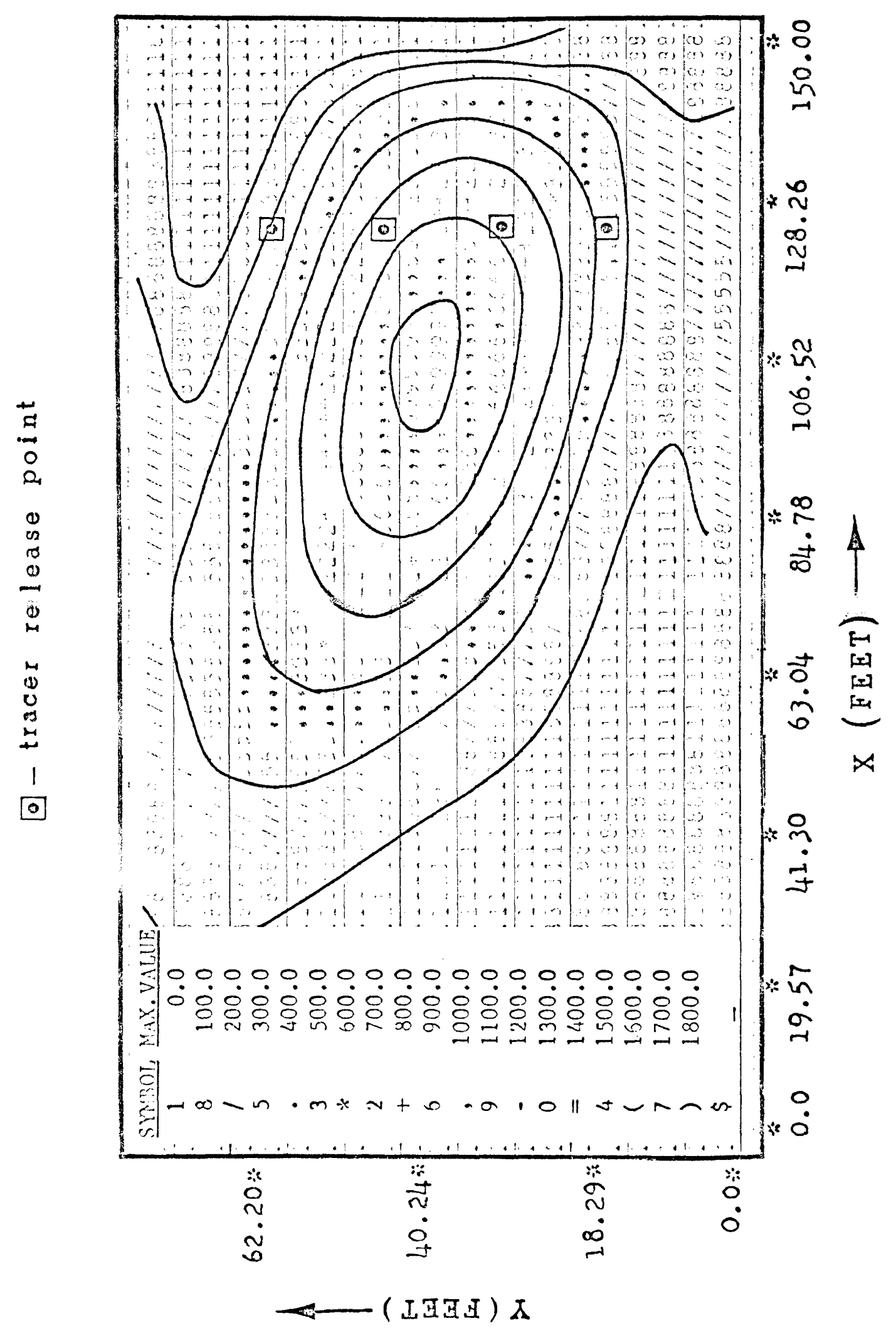


Flgure 11. Fourier trend concinuous symbol map of tracer particle concentration 40 win. after release (contours added by the author). 


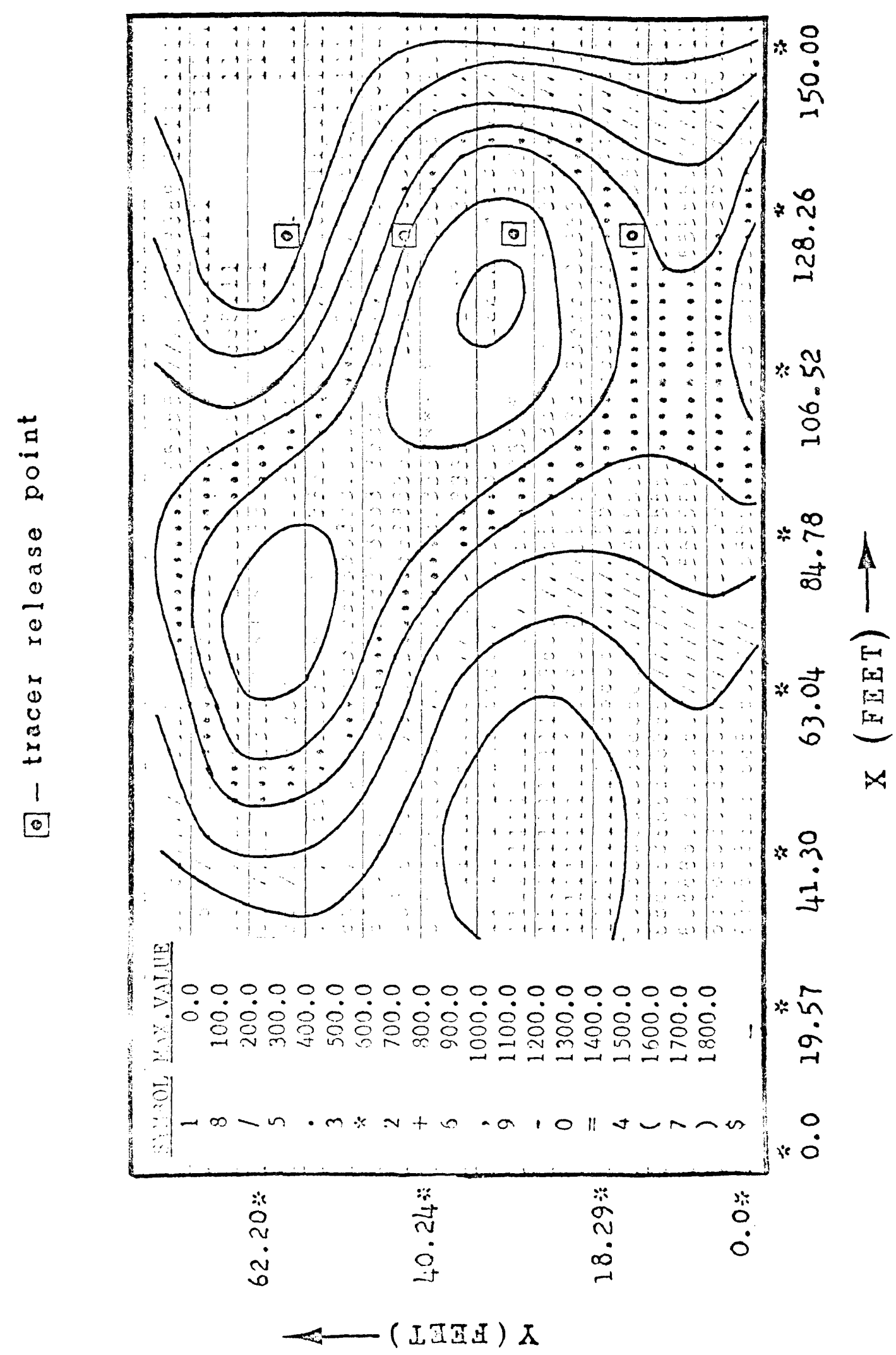


Figure 12. Fourlar tread continuou apmol map of tracer partiele concentration 50 min. after relenee (eontours added by the author). 


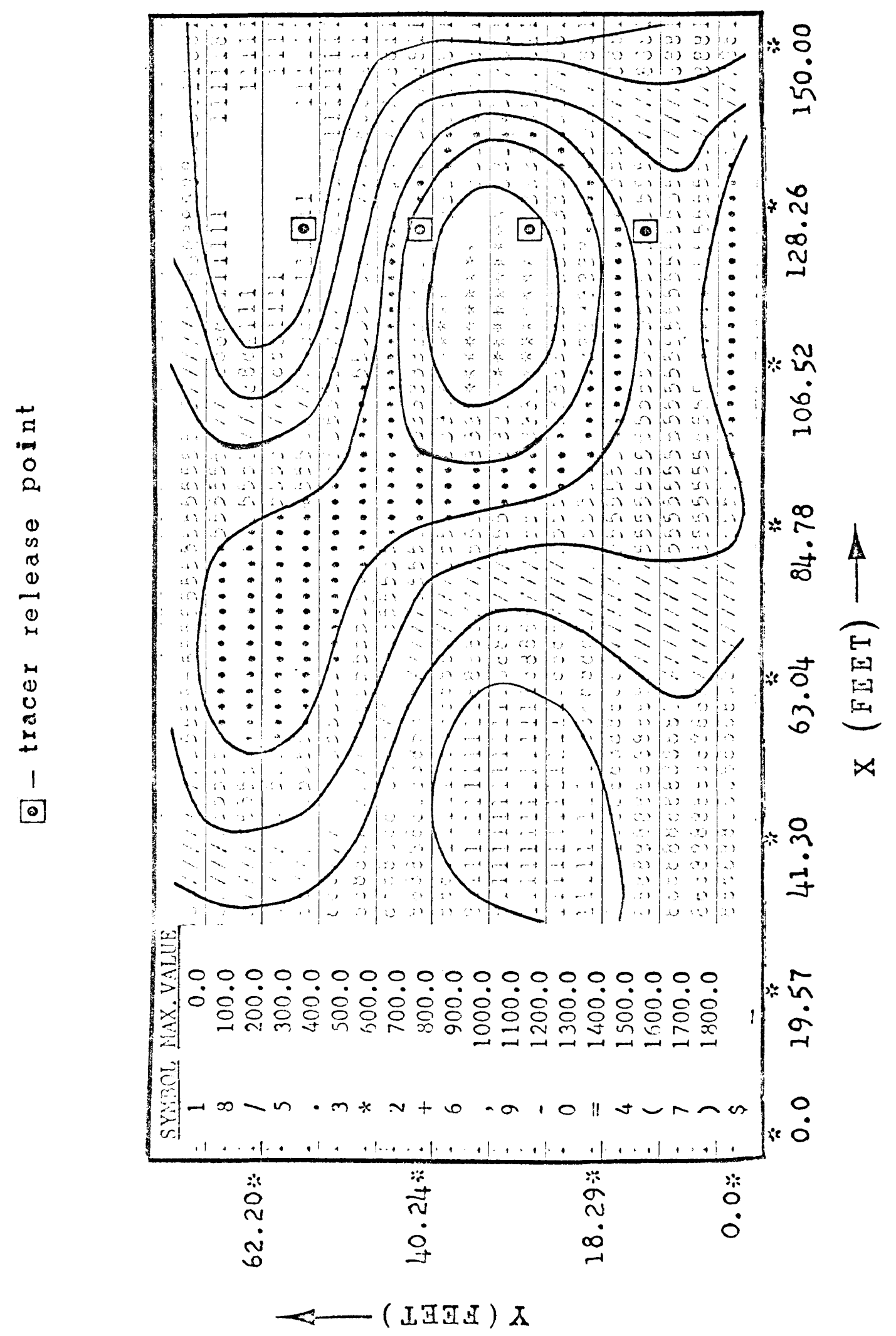


F1gure 13. Schenatic dingran howring derivation of blvartate displecenent date for 1 recovered trecer partieles. 


$$
0<i \leq N ; N=\text { samplesize }
$$

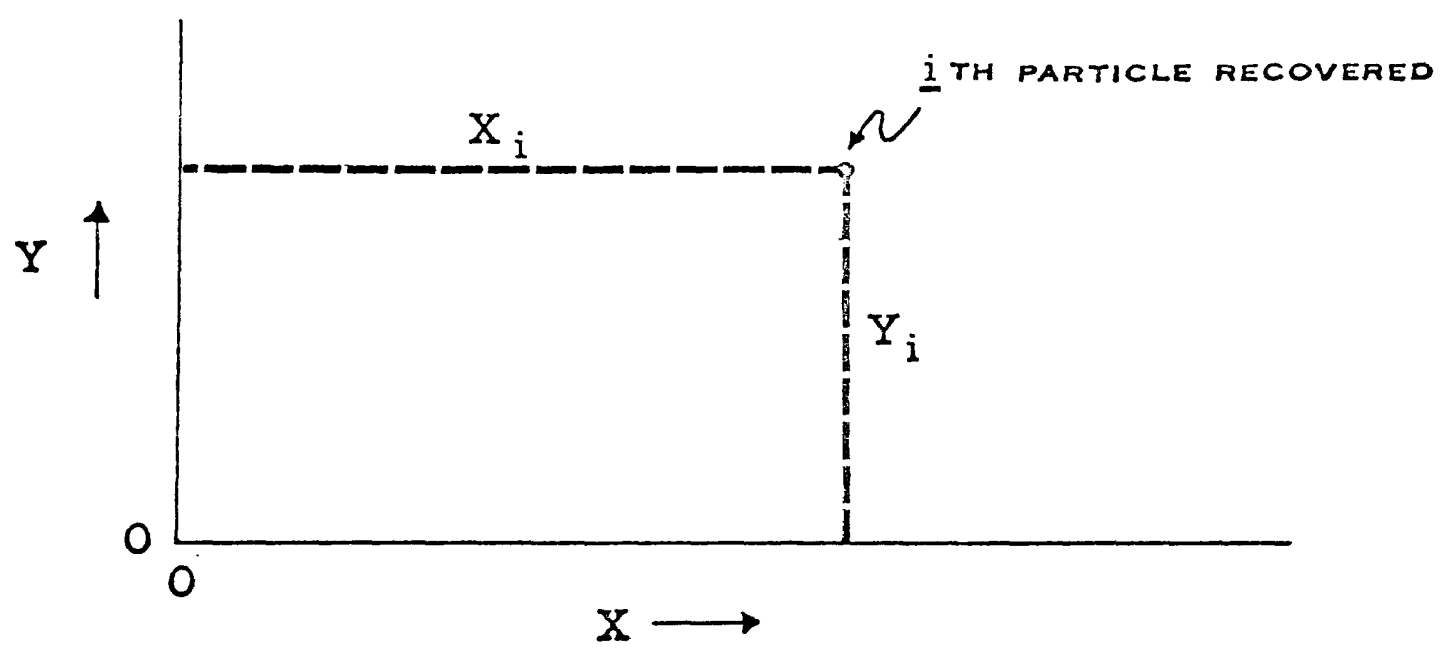




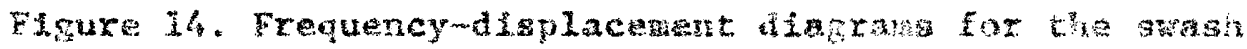
zone including fitted normal carpos, segt. 17, $110 \mathrm{~h}$ hros.. 


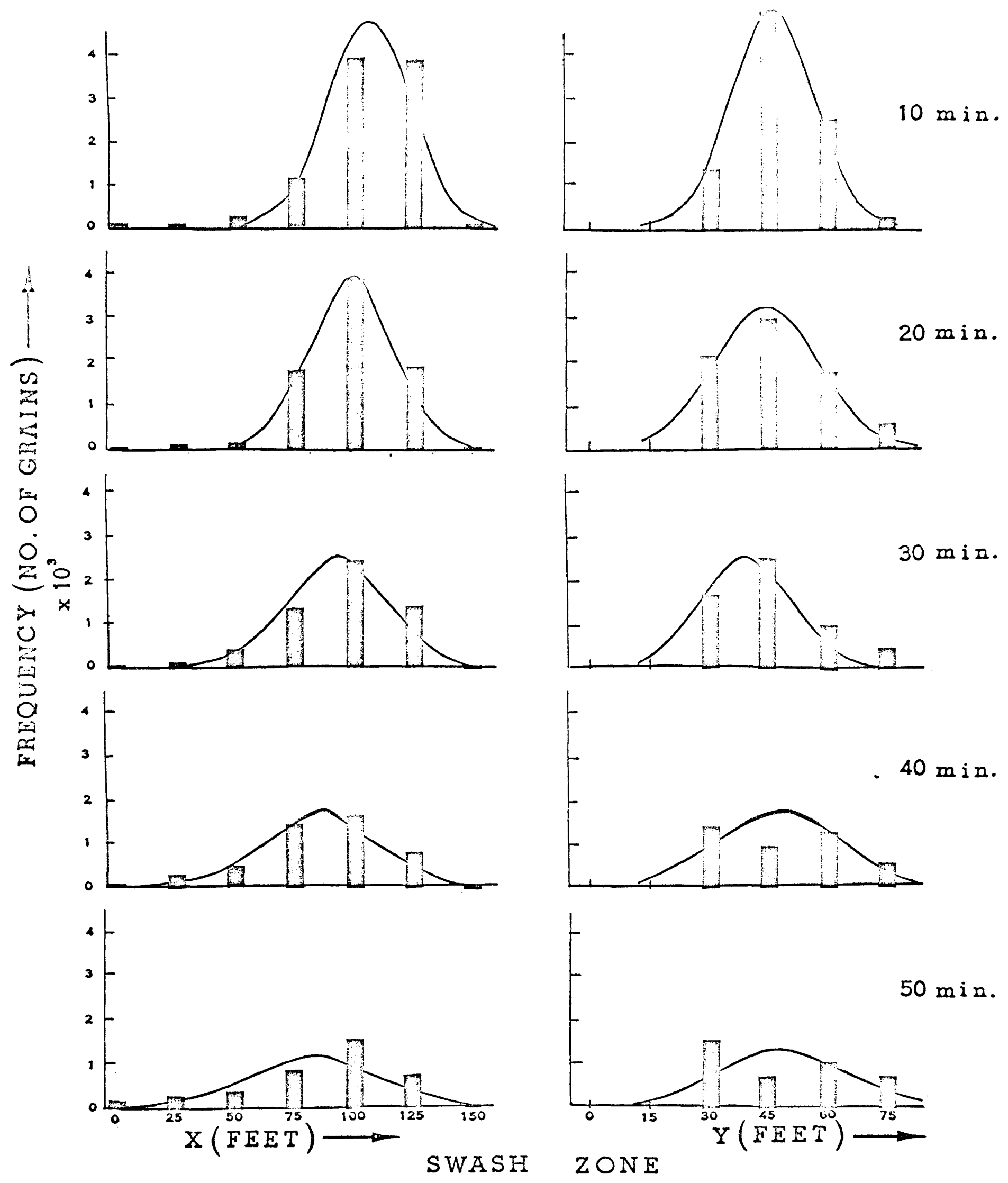


Igure 15. Frequeney-dieplacement diagrane for the surf sone lncluding fleted normal curves, Sept. 17. $1100 \mathrm{hro}$. . 


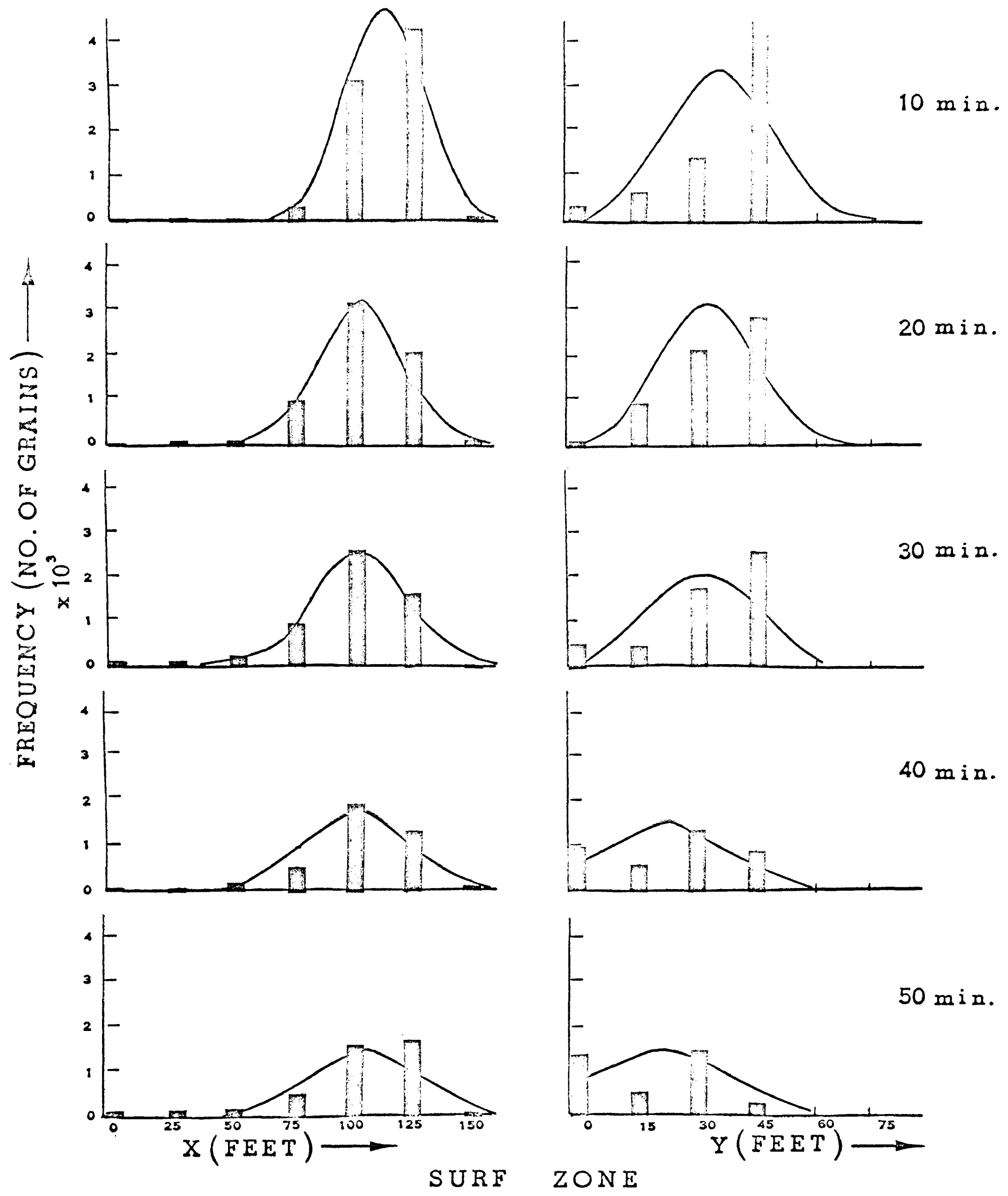


R1gure 16. TLme-dLeplacement diagrame showing group means with approxiante confidence intervals, sept. 17, $1100 \mathrm{hra}$. . 

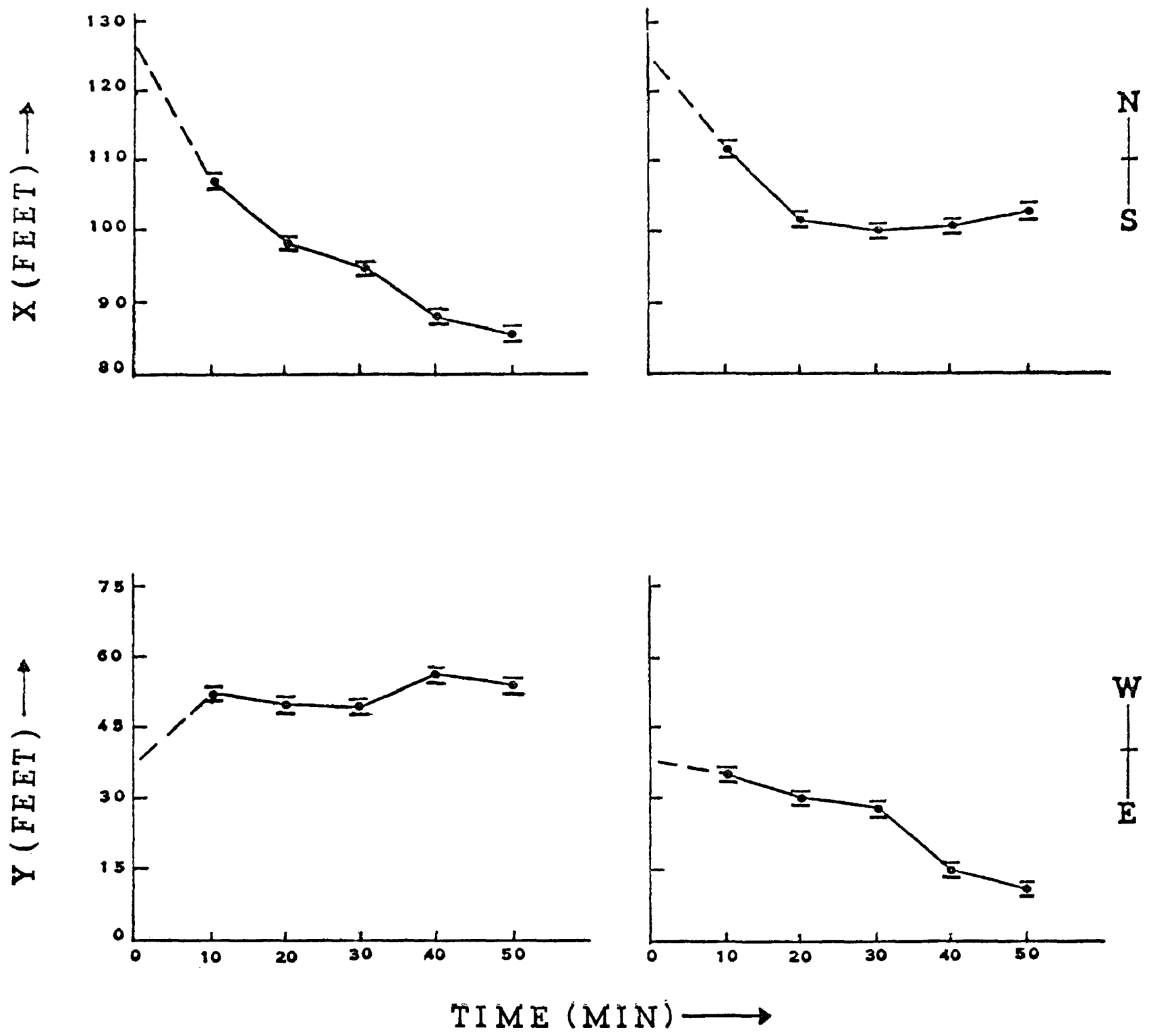

SWASH ZONE

SURF ZONE 
Flgure 17. Schenatic diagram showing the relationship between the poeltion of tracer particles, $x_{0}$ " upon Injection, and the "Impulae" dieplacenent, $X_{p}$, way from the Injection point Imodlately fbilowing release. The sane relationship holds for the $Y$ direction. 


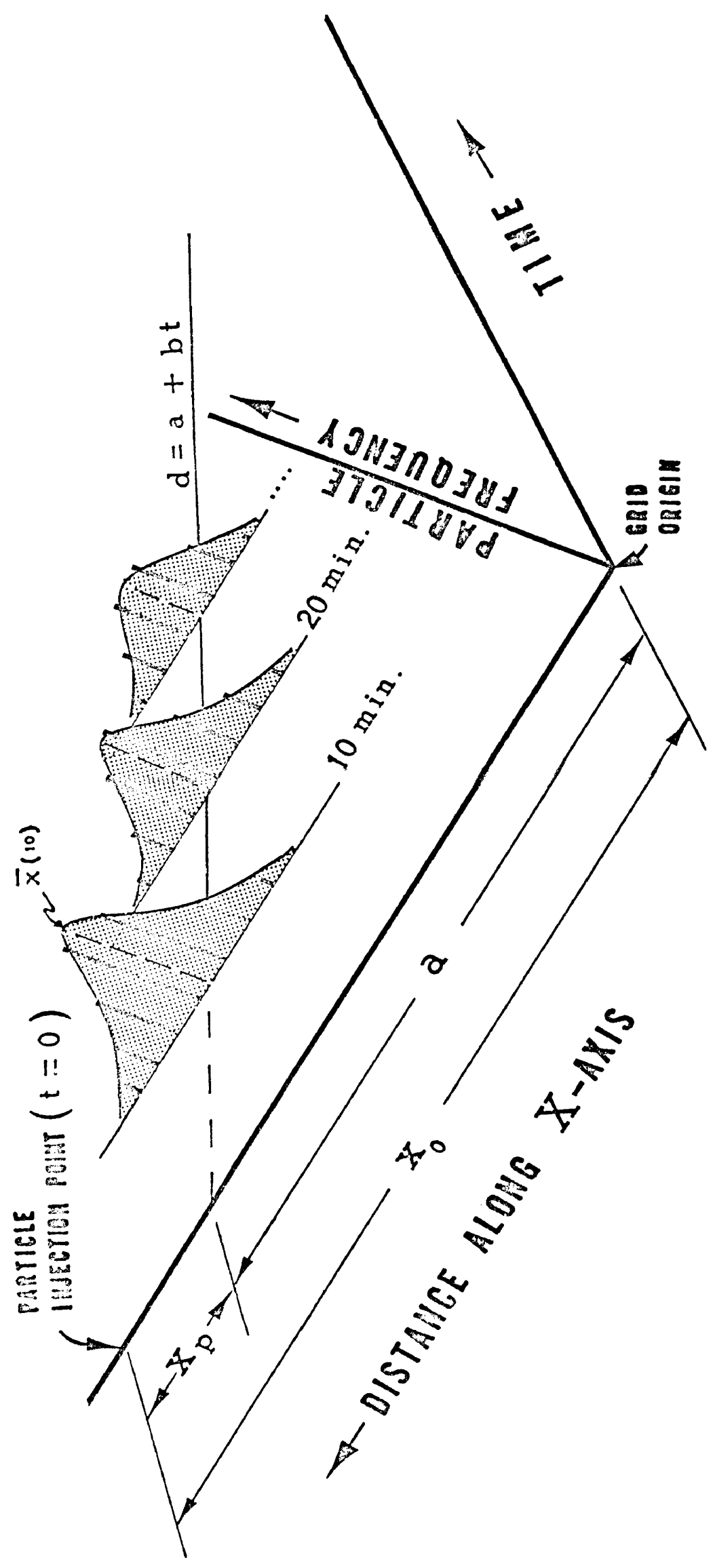


Figure 18. Schematie representation of tracer particle dilution ofth the in a eand metrix and aubequent moes" of tracer at depth. 

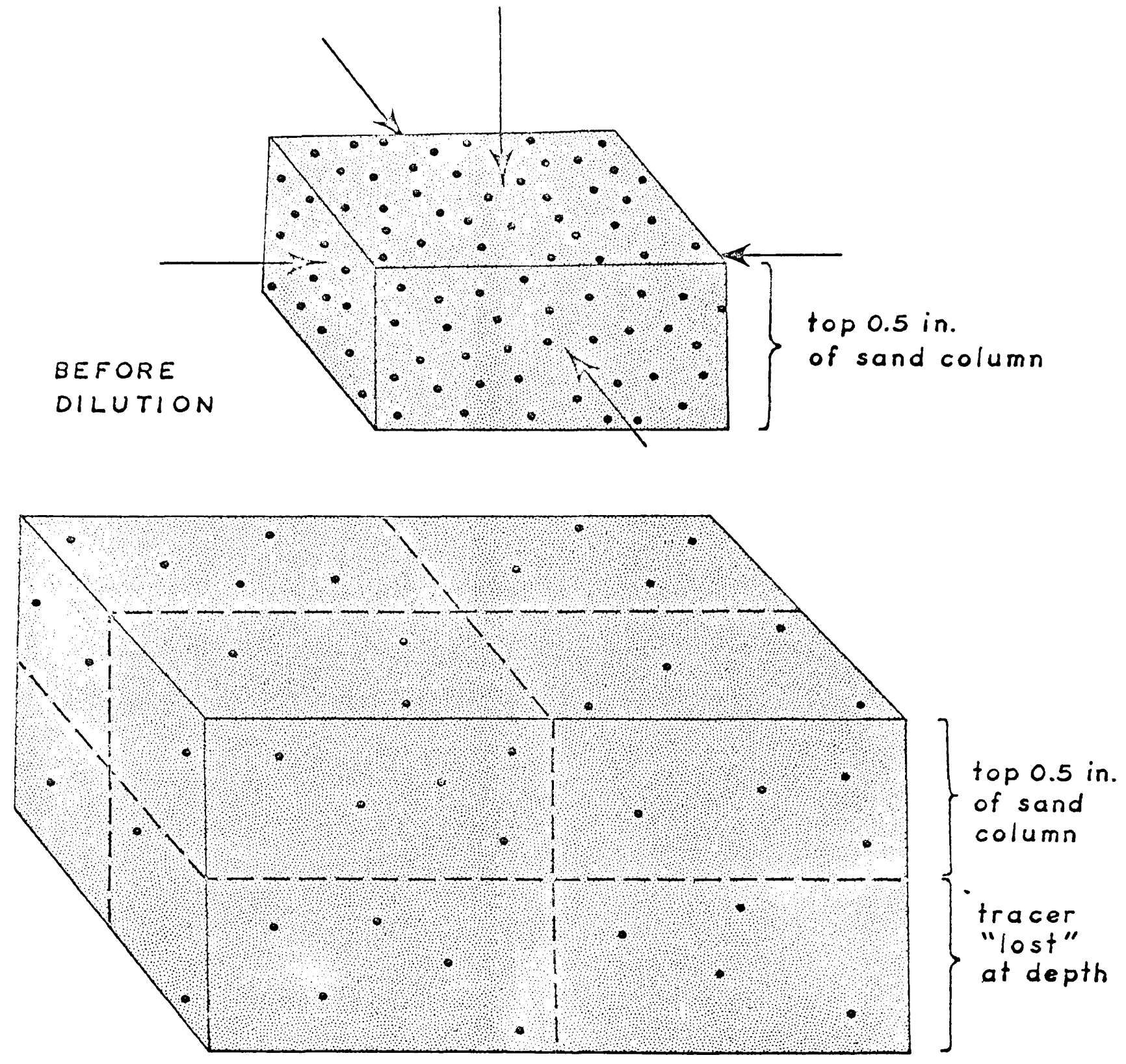

AFTER

DILUTION 
Figure 19. Tiae-frequency graph for tracer particles recovared by Yasso (1963) at Sandy Hook, Hew Jersey. 


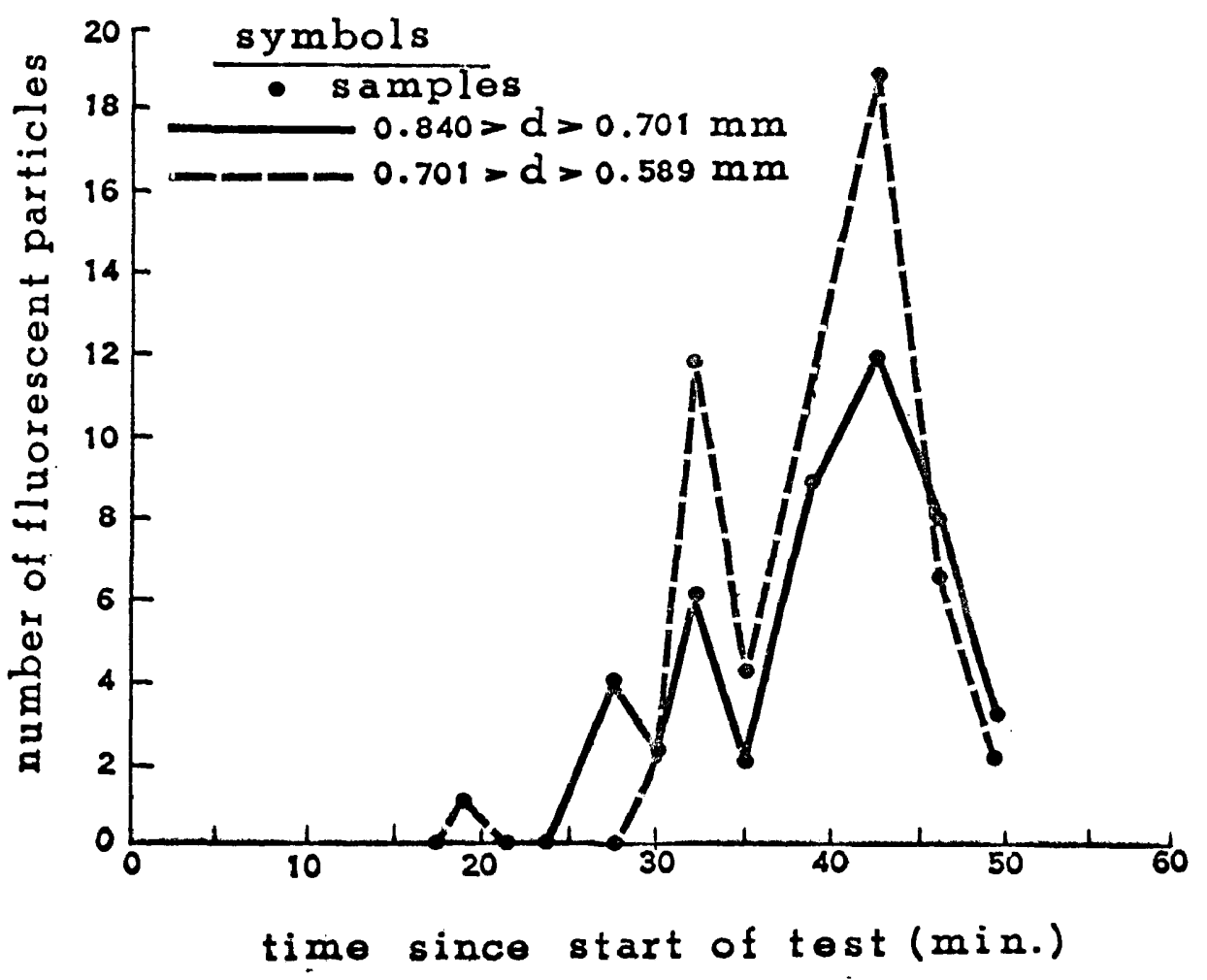


TABLE I

List of onvironmental factors measured near Pendelton Transect, September 16, 2200 hrs. (HW), and September 17, 1100 hrs. (HW), 1966.*

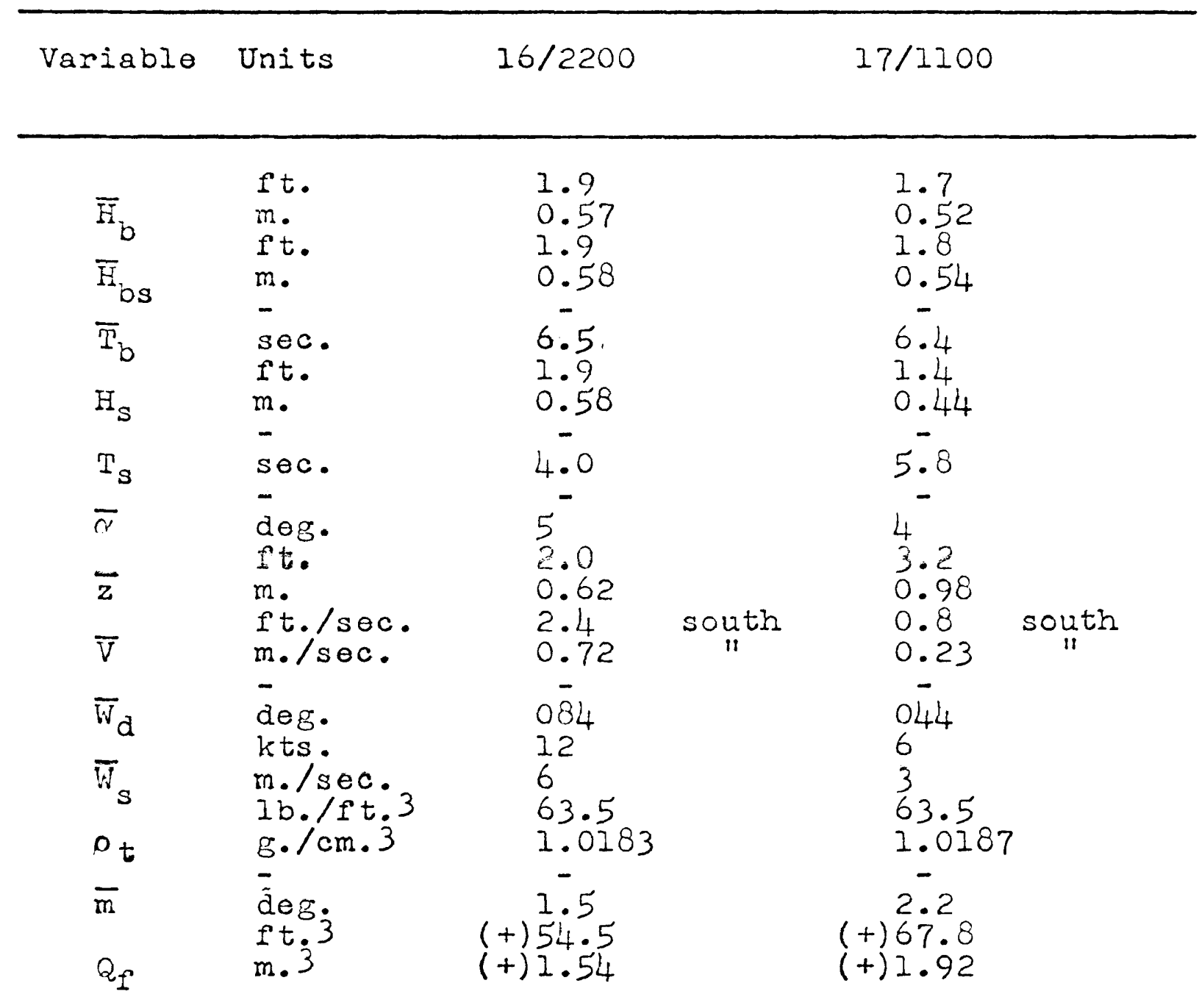

For an explanation of symbols, refer to text. 
Tracer concontration lata

\begin{tabular}{|c|c|c|c|c|c|}
\hline CONTRUL & $X\left(f t_{0}\right)$ & $Y(f t)$. & $10 \mathrm{~min}$. & $20 \mathrm{~min}$. & $30 \mathrm{~min}$. \\
\hline$A A 1$ & 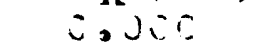 & 750000 & $1.00 \mathrm{C}$ & 20006 & $40 C \subset C$ \\
\hline AA2 & $\hat{C} \cdot C \mathrm{C}$ & $0 \therefore .000$ & $3=000$ & $1,00 c$ & 3. $C C D$ \\
\hline$\triangle A B$ & 0.062 & $45 n 302$ & 40006 & 3.000 & 4,500 \\
\hline AAG & 0.00 & 30,000 & $\varepsilon_{0} 006$ & 3.000 & 70.20 \\
\hline AA 5 & $C . C C C$ & 250030 & 15.066 & 2.306 & $3.56 c$ \\
\hline$A A E$ & $C .200$ & $\therefore .000$ & 4.200 & 20000 & 5.000 \\
\hline$A B I$ & 250000 & $7500: 2$ & 4306 & $19=00$ & $24: 003$ \\
\hline$A B 2$ & 25.200 & 600000 & 11000 & 2000 & 310000 \\
\hline$A B 3$ & 25.003 & 45,000 & 40006 & 14.000 & $12=0 \mathrm{CO}$ \\
\hline$A B 4$ & 25.000 & 30.000 & 7.000 & 3.000 & $1 \therefore<00$ \\
\hline$A 85$ & 250000 & 15,030 & 20006 & $30=0$ & 9.250 \\
\hline$A B G$ & 25,000 & $\therefore .000$ & 12000 & 19.000 & 6.000 \\
\hline$B B I$ & 50.000 & 75.000 & 3.000 & 90,000 & $3 i<60$ \\
\hline 832 & 50.000 & 60.000 & $78,00 \mathrm{C}$ & $37.00 C$ & $2: 5,600$ \\
\hline 833 & 50.000 & 450000 & 12,006 & 19.06 & 72.000 \\
\hline 834 & 50.000 & 30.003 & 12000 & 130000 & 36,000 \\
\hline $8 B 5$ & 50,000 & 15.000 & $1: 000$ & 9000 & 31.000 \\
\hline$B B E$ & 50.000 & 0.000 & 1.006 & $4: 000$ & 250600 \\
\hline$B C 1$ & 75.000 & 75.00 & 185086 & 258.020 & $? 61.000$ \\
\hline $8 C 2$ & 75.000 & 60.000 & 853.006 & 6690000 & 3420060 \\
\hline$B C 3$ & 75.000 & 45.003 & 83.006 & $869.0 \mathrm{CC}$ & 6810060 \\
\hline $13 C_{4}$ & 75.003 & 30.000 & 89.000 & 84.000 & $181=060$ \\
\hline $3 C 5$ & 75.000 & 15,000 & 23.000 & 15.000 & $46: 000$ \\
\hline 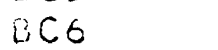 & 75.000 & SoOco & $99,00 \mathrm{~L}$ & $105: \mathrm{JCO}$ & 96,020 \\
\hline $\mathrm{CCI}$ & 100.000 & 75,000 & 65.006 & 302.02 & 1650.50 \\
\hline $\mathrm{CC} 2$ & 100.000 & 60.000 & 1099.006 & 736,000 & $333=000$ \\
\hline$C C 3$ & 100,000 & 45.000 & 26090000 & 2005.000 & 14850000 \\
\hline CC4 & 100,000 & 30.000 & $216=006$ & 911.000 & 625.605 \\
\hline $\mathrm{CC} 5$ & 100.000 & 15.000 & 99,000 & 305.060 & 2290600 \\
\hline $\operatorname{cc} 6$ & 2000000 & $\therefore=000$ & $180=206$ & 11.00 & $225 c \leq 0$ \\
\hline $\mathrm{COL}$ & 125.000 & 750000 & 27.00 & 19000 & 10000 \\
\hline $\cos 2$ & 125.000 & 60.300 & 4170006 & 3700000 & 142,000 \\
\hline $\mathrm{cos}$ & 125.000 & 45.000 & 24350000 & 187.000 & 322.000 \\
\hline 604 & 125.000 & 30,000 & 11190000 & 1216.000 & $8730 \mathrm{CCO}$ \\
\hline $\operatorname{COS}$ & $125,0=0$ & 15.062 & 654.000 & $653.00 \mathrm{C}$ & 207.000 \\
\hline CDE & 125,000 & 0.000 & 910006 & $15.0 \% 6$ & 281,000 \\
\hline 001 & $15 \mathrm{c} \cdot \mathrm{Scc}$ & 750000 & 1000 & 1. OC & $2: \therefore i$ \\
\hline DU2 & 150.000 & $6 r .003$ & 30005 & $3=050$ & $1: 202$ \\
\hline D0 3 & 150,000 & 45.000 & 1.006 & 2.00 & 10000 \\
\hline 004 & 1500000 & 30.000 & 1.005 & 2.000 & 4.000 \\
\hline 005 & 250.000 & 15,000 & 9.006 & $2: 000$ & 1.000 \\
\hline 006 & 150,000 & 0.000 & $100 \mathrm{cc}$ & 1.000 & 10000 \\
\hline
\end{tabular}

*

First two letters of control indicate column, last digit indicates row beginning with the shoreward: most row as 1 . 
TABLE 2 (CONT.)

\begin{tabular}{|c|c|c|c|c|}
\hline CONTRUL & $x\left(f^{\prime} t_{0}\right)$ & $Y(\because \cdots)$ & $40 \mathrm{~min}$. & $50 \mathrm{~min}$. \\
\hline$A \wedge 1$ & 0.000 & 75.000 & 50000 & $21 \cdot 0 \mathrm{CC}$ \\
\hline$A \wedge 2$ & $\mathrm{C}, \mathrm{CO}=$ & 60.060 & $1 \mathrm{C}=000$ & 49,000 \\
\hline$A \wedge 3$ & 0.000 & 45.200 & 210000 & 63,00 \\
\hline$A \wedge C_{1}$ & 0,000 & 30,000 & 2,000 & $6=20$ \\
\hline AA 5 & $C=000$ & 15.000 & 5.000 & 9.06 \\
\hline$A A C$ & 0.200 & Cocco & 4.000 & 5,00 \\
\hline$\triangle 81$ & 25.000 & 750000 & 44.000 & 60,00 \\
\hline$A B ?$ & 25000 & 0.0000 & 137.000 & 164,00 \\
\hline$A B 3$ & 250003 & 45,000 & 27.000 & $23,0 C$ \\
\hline$A B 4$ & 25.000 & 30.005 & 2.000 & 12.00 \\
\hline$A B 5$ & 250002 & $15,0: 0$ & $18=000$ & 10,50 \\
\hline$A B G$ & 25.000 & 0.000 & 20000 & 17,00 \\
\hline$B B I$ & 50.000 & $75 \mathrm{coc}$ & $77, \mathrm{CCO}$ & $168=50$ \\
\hline 832 & 50.000 & 60.000 & 182.000 & 131.00 \\
\hline 833 & 50.000 & 450000 & 74,000 & 47.00 \\
\hline$B B 4$ & 50.000 & 30.000 & 36.000 & 53,00 \\
\hline$B B 5$ & 50.000 & 15.000 & 7.000 & 3,0 \\
\hline$B B C$ & 500000 & 0.000 & 46.000 & 65.0 \\
\hline$B C 1$ & 75.000 & 75.000 & 399.000 & $302: 0$ \\
\hline$B C 2$ & 750000 & $6000=0$ & 7150000 & 435,6 \\
\hline $\mathrm{BC} 3$ & 75.000 & $45: 000$ & 2480000 & 84.0 \\
\hline$B C 4$ & 75.000 & 30.060 & 1080000 & $50: 7$ \\
\hline$B C 5$ & 75.000 & 15.000 & 112,000 & 202.0 \\
\hline$B C E$ & 75.000 & 0.000 & 107.000 & 121.0 \\
\hline $\mathrm{CCl}$ & 100.000 & 75.000 & 185.000 & 161,0 \\
\hline $\mathrm{CC} 2$ & 100.000 & 60.000 & 3390000 & $316: 0$ \\
\hline $\mathrm{CC} 3$ & 100.000 & 45.000 & 501.000 & $409=0$ \\
\hline CC4 & 100,000 & 300000 & 651,000 & $717 . \mathrm{C}$ \\
\hline CC5 & 100.000 & 15.000 & 3110000 & 148.00 \\
\hline $\operatorname{cc} 6$ & 1000000 & $\mathrm{CoC} 0 \mathrm{O}$ & 503.000 & 423.00 \\
\hline CDI & 125,000 & 75000.9 & 15,000 & $13 . \%$ \\
\hline $\mathrm{CO} 2$ & 125.000 & 60.000 & 11.000 & 10.0 \\
\hline $\mathrm{CD} 3$ & 125.000 & 45.000 & $147=000$ & 120,00 \\
\hline CD 4 & 125.000 & 30,000 & 703.000 & 690.01 \\
\hline CD 5 & $125.00 \mathrm{C}$ & 15.002 & 1580000 & 104.0 \\
\hline COE & $125, \mathrm{COC}$ & 0.000 & 461.000 & $8 C 5=0$ \\
\hline DDI & 150.000 & 750000 & 1,000 & 5,0 \\
\hline 002 & 150.000 & 600000 & 1.000 & 5.0 \\
\hline DDI & 150.000 & 45.000 & 3.000 & $1=0$ \\
\hline 004 & 150.000 & 30.000 & 2.000 & 1.0 \\
\hline 005 & 150.000 & 150000 & 5.000 & $41:$ \\
\hline 006 & 150.000 & 0.000 & 2.006 & $10 i$ \\
\hline
\end{tabular}


TABLE 3

Summary of chi-square tests, zones versus $X$ displacomonts.

\begin{tabular}{cccc}
\hline $\begin{array}{c}\text { Time } \\
(\min .)\end{array}$ & d.f. & $\lambda^{2}$ & Probability \\
10 & 6 & 596.7 & $P<0.001$ \\
20 & 6 & 190.6 & $P<0.001$ \\
30 & 6 & 196.2 & $P<0.001$ \\
40 & 6 & 732.2 & $P<0.001$ \\
50 & 6 & 672.4 & $P<0.001$ \\
\hline
\end{tabular}


TALE 4

Computer output of prost mu in'

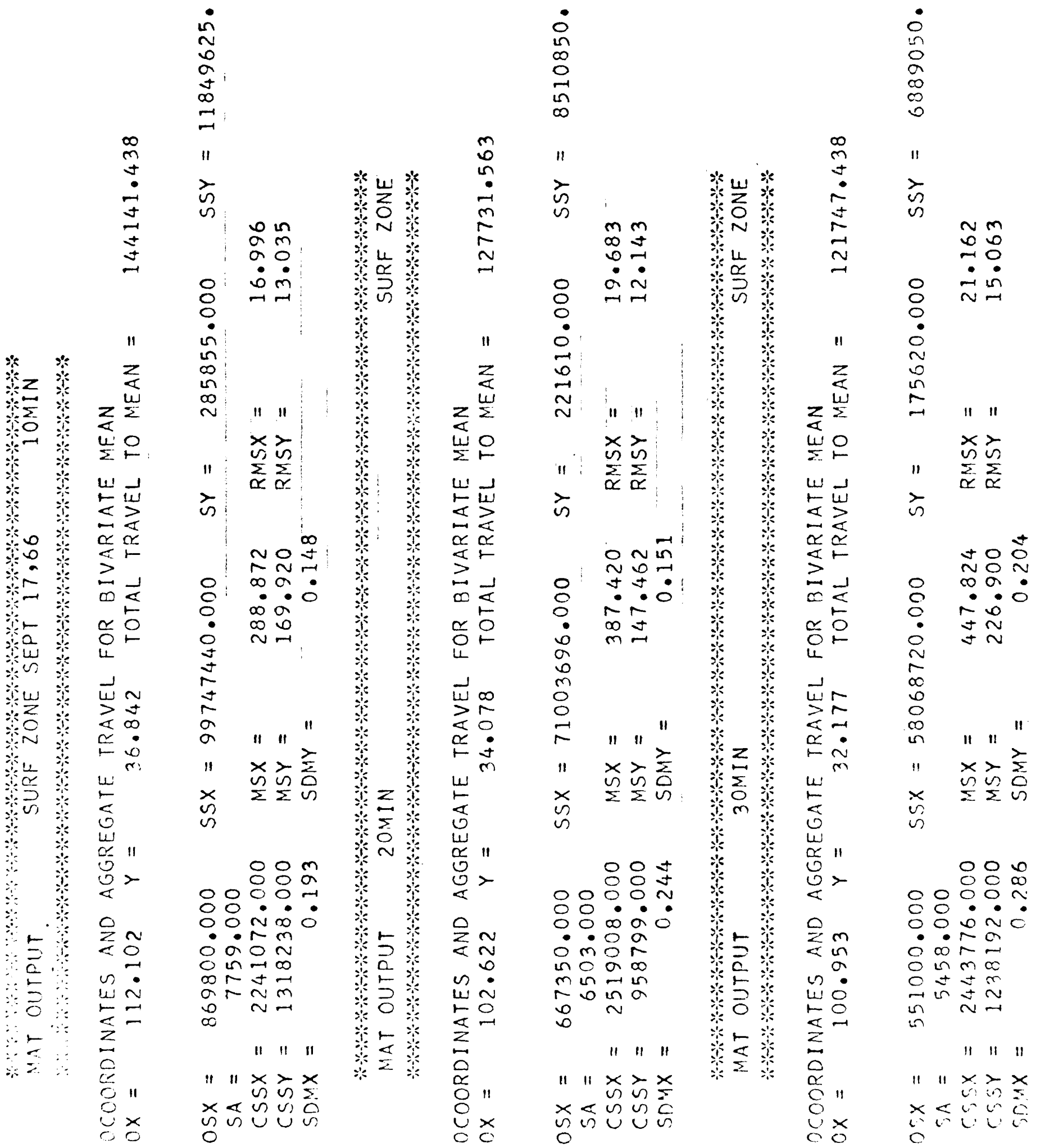


TABLE 4 (Cowr.)

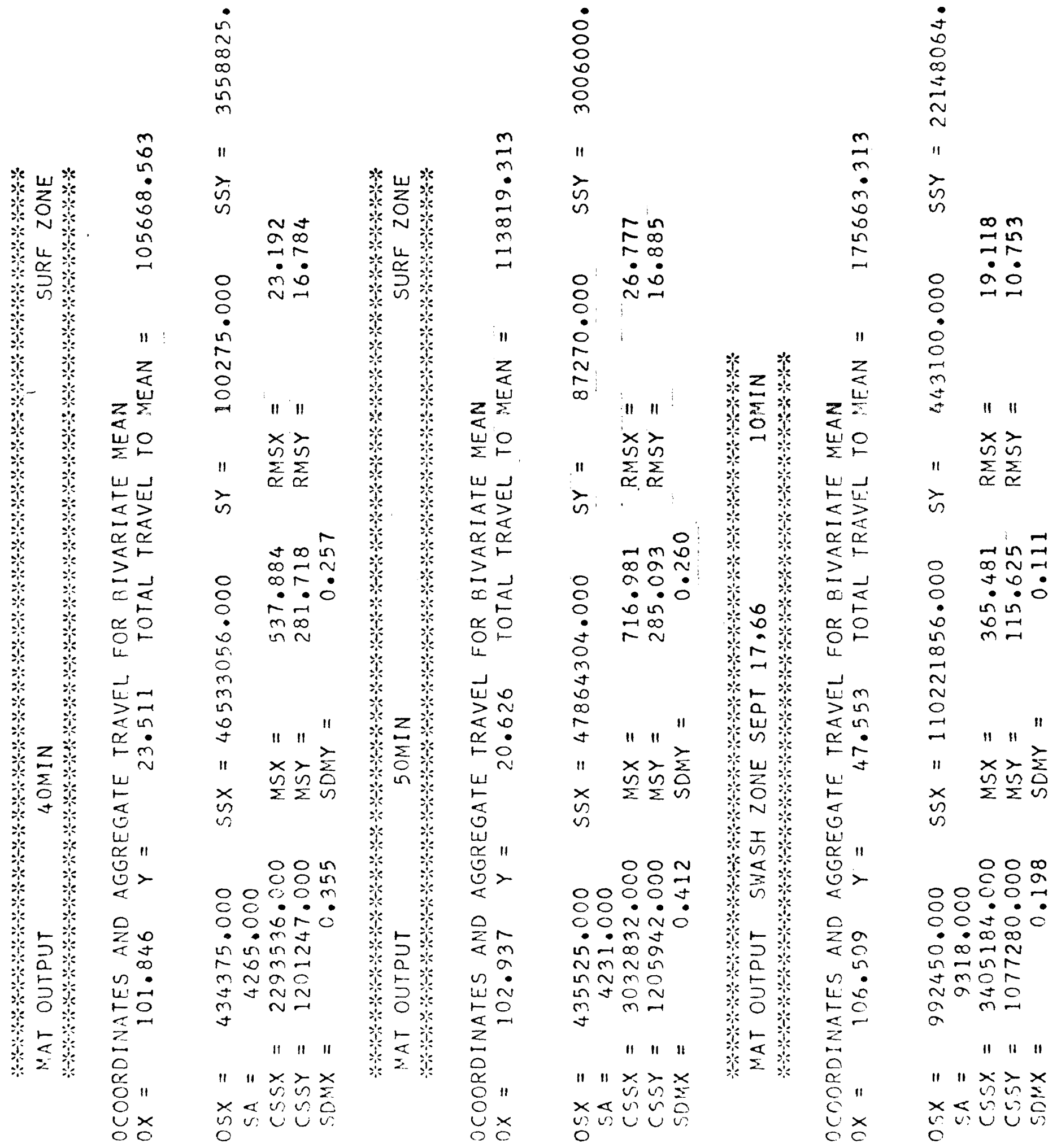




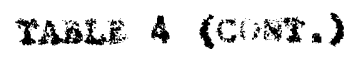

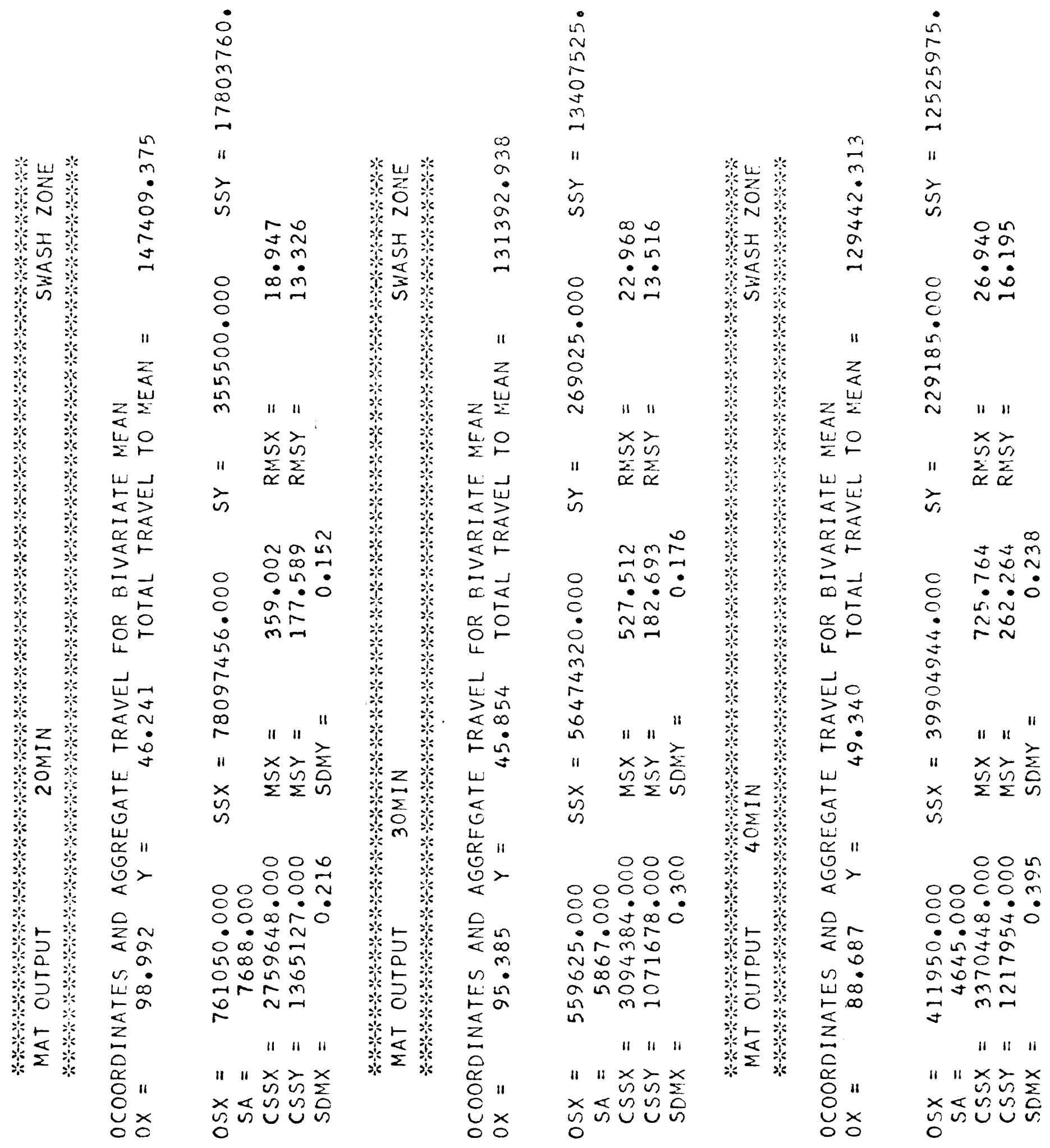


TAaL 4 (CONT.)

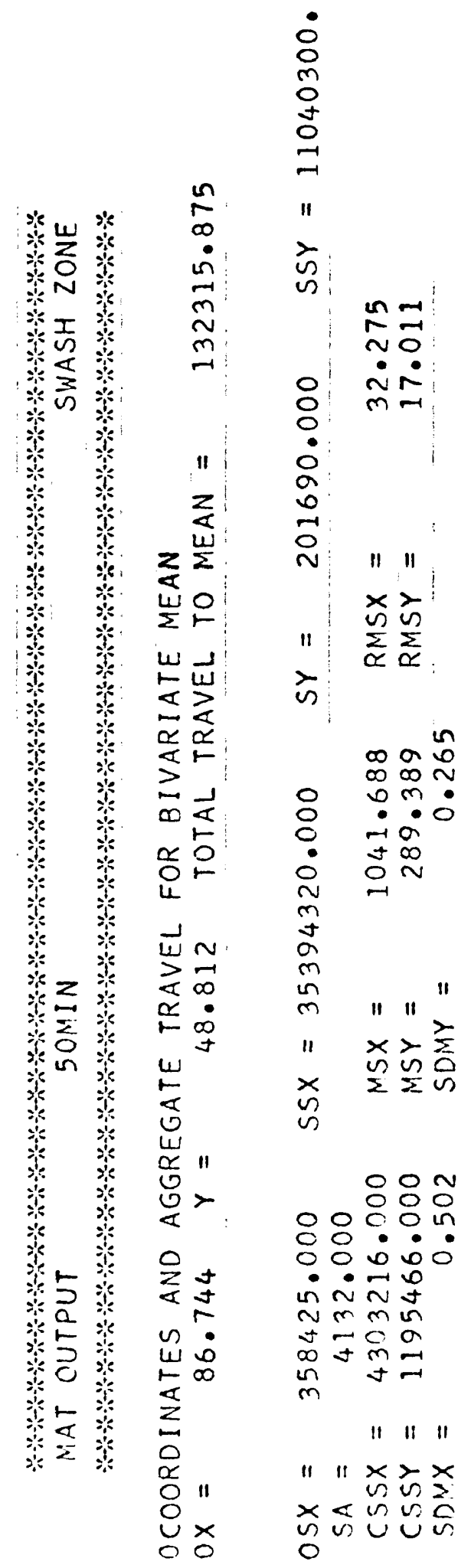


TABLE 5

Pendelton tracor data, $X$ dispiacoments; " $t$ " tests of $\mathrm{H}_{0}: \mu_{I}=l_{2}$ for four pairs of group mean data per dynamic zono.

SURF ZONE, 10-20 MIN. SERIES

\begin{tabular}{|lllll|}
\hline Sample & Size & $\bar{X}$ & MSX & SDIN \\
\hline 10 min. 7759 & 112.102 & 288.872 & 0.193 \\
20 min. & 6503 & 102.622 & 387.420 & 0.244 \\
\hline $\bar{X}_{20}-\bar{X}_{10}=-9.480$ & $F=1.341$ & \\
$t=-30.48, P<$ & $0.05, H_{0}$ rejected \\
\hline
\end{tabular}

SURF ZONE, 20-30 MIN. SERIES

\begin{tabular}{|lllll|}
\hline Sample & Size & $\bar{X}$ & MSX & SDMX \\
\hline 20 min. & 6503 & 102.622 & 387.420 & 0.244 \\
30 min. & 5458 & 100.953 & 447.824 & 0.286 \\
\hline $\bar{x}_{30}-\bar{X}_{20}=-1.669$ & $F=1.156$ & \\
$t=-4.44, P<$ & 0.05 & Ho rejected \\
\hline
\end{tabular}

SURF ZONE, $30-40$ MIN. SERIES

\begin{tabular}{|c|c|c|c|c|}
\hline Sample & $\operatorname{Siz} \theta$ & $\overline{\mathrm{X}}$ & MSX & SDMX \\
\hline $\begin{array}{l}30 \mathrm{~min} . \\
40 \mathrm{~min} .\end{array}$ & $\begin{array}{l}5458 \\
4265\end{array}$ & $\begin{array}{l}100.953 \\
101.846\end{array}$ & $\begin{array}{l}447.824 \\
537.884\end{array}$ & $\begin{array}{l}0.286 \\
0.355\end{array}$ \\
\hline $\begin{array}{c}\bar{X}_{40}-\bar{x}_{3} \\
t=1 .\end{array}$ & $\begin{array}{l}=0.893 \\
P>0.0\end{array}$ & $\mathrm{H}_{0}$ not & $\begin{array}{l}F=1.201 \\
\text { rejected }\end{array}$ & \\
\hline
\end{tabular}


TABLE 5 (CONIIN.)

SURE ZONE, 40-50 MIN. SERIFIS

\begin{tabular}{|c|c|c|c|c|}
\hline Samplo & Size & $\overline{\mathrm{X}}$ & $\operatorname{MSX}$ & SDMX \\
\hline $\begin{array}{l}40 \mathrm{~min} . \\
50 \mathrm{~min} .\end{array}$ & $\begin{array}{l}4265 \\
4231\end{array}$ & $\begin{array}{l}101.846 \\
102.937\end{array}$ & $\begin{array}{l}537.884 \\
716.981\end{array}$ & $\begin{array}{l}0.355 \\
0.47 .2\end{array}$ \\
\hline \multicolumn{5}{|c|}{$\begin{array}{ll}\bar{X}_{50}-\bar{X}_{40}=1.091 & F=1.333 \\
t=2.01, & P<0.05,\end{array}$} \\
\hline
\end{tabular}

SWASH ZONE, 10-20 MIN. SERIFS

\begin{tabular}{|lllll|}
\hline Sample & Size & $\bar{X}$ & MSX & SDMX \\
\hline I0 min. 9318 & $\begin{array}{l}106.509 \\
98.992\end{array}$ & $\begin{array}{l}365.481 \\
359.002\end{array}$ & $\begin{array}{l}0.198 \\
0.216\end{array}$ \\
\hline $\bar{X}_{20}-\bar{X}_{10}=-7.517$ & $F=1.018$ & \\
$t=-25.66, P<0.05, H_{0}$ rejected & \\
\hline
\end{tabular}

SWASH ZONE, 20-30 MIN. SERIES

\begin{tabular}{|ccccc|}
\hline Sample & Size & $\bar{X}$ & MSX & SDMX \\
\hline $\begin{array}{l}20 \text { min. } \\
\text { 30 min. }\end{array} 5868$ & 98.992 & 359.002 & 0.216 \\
& 95.385 & 527.512 & 0.300 \\
\hline $\bar{x}_{30}-\bar{x}_{20}=-3.607$ & $F=1.469$ & \\
$t=-9.75, P<$ & $0.05, H_{0}$ rejected \\
\hline
\end{tabular}


TABLE 5 (CONTIN.)

SWASH ZONE, 30-40 MIN. SERIFIS

\begin{tabular}{|c|c|c|c|c|c|}
\hline Sample & Sizo & $\bar{x}$ & MSX & SDMX & \\
\hline $\begin{array}{l}30 \mathrm{~min} . \\
40 \mathrm{~min} .\end{array}$ & $\begin{array}{l}5867 \\
4645\end{array}$ & $\begin{array}{l}95.385 \\
88.687\end{array}$ & $\begin{array}{l}527.512 \\
725.764\end{array}$ & $\begin{array}{l}0.300 \\
0.395\end{array}$ & • \\
\hline $\begin{array}{l}\bar{x}_{40}-\bar{x}_{30} \\
t=-1\end{array}$ & $\begin{array}{l}=-6 . \\
.50, P\end{array}$ & $25, \mathrm{H}_{0}=$ & $\begin{array}{l}F=1.376 \\
\text { jected }\end{array}$ & & \\
\hline
\end{tabular}

SWASH ZONE, 40-50 MIN. SERIES

\begin{tabular}{|lllll|}
\hline Sample & Size & $\bar{X}$ & MSK & SDMK \\
\hline 40 min. 46.45 & 88.687 & 725.764 & 0.395 \\
50 min. & 4132 & 86.744 & 1041.688 & 0.502 \\
\hline $\bar{X}_{50}-\bar{X}_{40}=-1.943$ & $F=1.435$ \\
$t=-3.04, P<0.05, H_{0}$ rejected \\
\hline
\end{tabular}




\section{TABLE 6}

Pondelton tracer data, Y displacomonts; "t" tosto of $\mathrm{H}_{\mathrm{O}}: \mu_{1}=\mu_{2}$ for four pairs of group riean data por dynamic zono.

SURP ZONE, 10-20 MTH. SERIES

\begin{tabular}{|ccccc|}
\hline Sample & Size & $\bar{Y}$ & MiSY & SDIMY \\
\hline I0 min. 7759 & 36.842 & 169.920 & 0.148 \\
20 min. & 6503 & 34.078 & 147.1462 & 0.151 \\
\hline $\bar{Y}_{20}-\bar{Y}_{10}=-2.764$ & $F=1.1 .52$ & \\
$t=-13.1, P<$ & 0.005, IIO rejected \\
\hline
\end{tabular}

SURF ZONE, 20-30 MIN. SERIES

\begin{tabular}{|lllll|}
\hline Sample & Size & $\bar{Y}$ & MSY & SDMY \\
\hline 20 min. & 6503 & 34.078 & 147.4 .62 & 0.351 \\
30 min. & 5458 & 32.177 & 226.900 & 0.204 \\
\hline $\bar{Y}_{30}-\bar{Y}_{20}=-1.901$ & & $F=1.539$ \\
$t=-7.48, P<0.05$, Ho_rejected \\
\hline
\end{tabular}

SURF ZONE, 30-40 NIN. SERIES

\begin{tabular}{|c|c|c|c|c|}
\hline Sample & Size & $\bar{Y}$ & MSY & SDMY \\
\hline $\begin{array}{l}30 \mathrm{~min} . \\
40 \mathrm{~min} .\end{array}$ & $\begin{array}{l}5458 \\
4265\end{array}$ & $\begin{array}{l}32.177 \\
23.511\end{array}$ & $\begin{array}{l}226.900 \\
281.718\end{array}$ & $\begin{array}{l}0.204 \\
0.257\end{array}$ \\
\hline \multicolumn{5}{|c|}{ 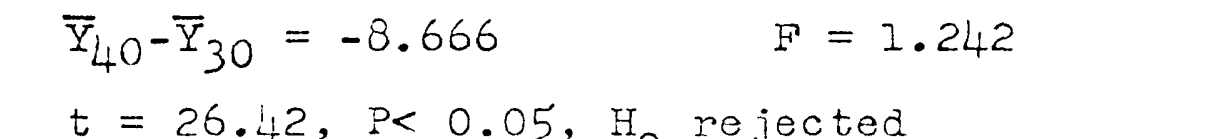 } \\
\hline
\end{tabular}


PABLE 6 (CONTIN.)

SURF ZONE, 1,0-OO TAN. SERIES

\begin{tabular}{|c|c|c|c|c|}
\hline Sample & Size & $\bar{Y}$ & MSY & SDrYY \\
\hline $\begin{array}{l}40 \text { min. } \\
50 \text { min. }\end{array}$ & $\begin{array}{l}4265 \\
4231\end{array}$ & $\begin{array}{l}23.511 \\
20.626\end{array}$ & $\begin{array}{l}281.718 \\
285.093\end{array}$ & $\begin{array}{l}0.257 \\
0.260\end{array}$ \\
\hline $\begin{array}{l}\bar{Y}_{50}-\bar{Y}_{40} \\
t=-7 .\end{array}$ & $\begin{array}{l}=-2 . \\
90, P\end{array}$ & , $\mathrm{H}, \mathrm{r}$ & $\begin{array}{l}F=1.012 \\
\text { ected }\end{array}$ & \\
\hline
\end{tabular}

SWASH ZONE, 10-20 MIN. SERIES

\begin{tabular}{|lllll|}
\hline Sample & Size & $\overline{\mathrm{Y}}$ & MSY & SDIY \\
\hline $\begin{array}{l}\text { 10 min. } 9318 \\
20 \mathrm{~min} .\end{array}$ & $\begin{array}{l}47.558 \\
46.241\end{array}$ & $\begin{array}{l}115.625 \\
177.589\end{array}$ & $\begin{array}{l}0.111 \\
0.152\end{array}$ \\
\hline$\overline{\mathrm{Y}}_{20}-\overline{\mathrm{Y}}_{10}=-1.312$ & $\mathrm{~F}=1.536$ \\
$\mathrm{t}=6.98, \mathrm{P}<0.05, \mathrm{H}_{0}$ rejected \\
\hline
\end{tabular}

SWASH ZONE, 20-30 MIN. SERIES

\begin{tabular}{|c|c|c|c|c|}
\hline Samplo & Sizo & $\bar{Y}$ & MSY & SDNY \\
\hline $\begin{array}{l}20 \mathrm{~min} . \\
30 \mathrm{~min} .\end{array}$ & $\begin{array}{l}7688 \\
5867\end{array}$ & $\begin{array}{l}46.241 \\
45.854\end{array}$ & $\begin{array}{l}177.589 \\
182.693\end{array}$ & $\begin{array}{l}0.152 \\
0.176\end{array}$ \\
\hline \multicolumn{5}{|c|}{ 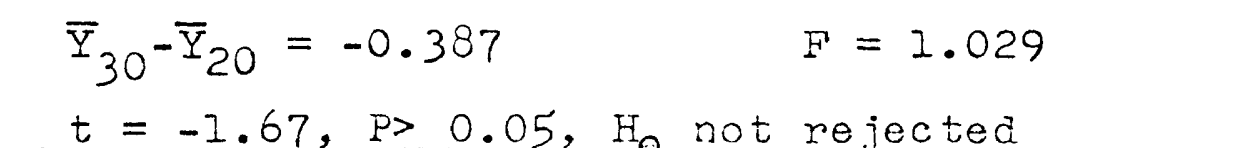 } \\
\hline
\end{tabular}


TABLE 6 (CONTIN.)

SWASH ZONE, 30-4O NIN. SERIES

\begin{tabular}{|c|c|c|c|c|}
\hline Sample & $\operatorname{Siz} \theta$ & $\bar{Y}$ & MSY & SDMY \\
\hline $\begin{array}{l}30 \mathrm{~min} . \\
40 \mathrm{~min},\end{array}$ & $\begin{array}{l}5867 \\
4645\end{array}$ & $\begin{array}{l}45.254 \\
49.340\end{array}$ & $\begin{array}{l}182.693 \\
262.264\end{array}$ & $\begin{array}{l}0.176 \\
0.238\end{array}$ \\
\hline \multicolumn{5}{|c|}{$\begin{array}{ll}\bar{Y}_{40}-\bar{Y}_{30}=3.486 & F=1.436 \\
t=11.78, P<0.05, & \text { He rected }\end{array}$} \\
\hline
\end{tabular}

SWASH ZONE, $40-50$ MIN. SERIES

\begin{tabular}{|c|c|c|c|c|}
\hline Sample & Size & $\bar{Y}$ & MSY & SDMY \\
\hline $\begin{array}{l}40 \mathrm{~min} . \\
50 \mathrm{~min} .\end{array}$ & $\begin{array}{l}4645 \\
4132\end{array}$ & $\begin{array}{l}49.340 \\
48.812\end{array}$ & $\begin{array}{l}262.264 \\
289.389\end{array}$ & $\begin{array}{l}0.238 \\
0.265\end{array}$ \\
\hline \multicolumn{5}{|c|}{$\begin{array}{ll}\bar{Y}_{50}-\bar{Y}_{40}=-0.528 & F=1.103 \\
t=-1.49, \quad P>0.05, \text { Ho not rejected }\end{array}$} \\
\hline
\end{tabular}




\section{LITERATUR CITED}

BAGAOLD, R.A., 1963, Mechaics of marke gedimentation. In: H.N. M111, E.D. Coldberg, C.O.D. Laelin, and W.Kf. Murk (Ealtore), the sea, ldeas and observations on progress in the study of the sess: Jom W11ey sons, Inc., v. 3, pp. 507-528.

BARTLETT, M.S., 1960, Stociastic population modals: John Wiley \& Sons, Iac., 84 p.

BOON, J.D., III, 1967, Trend surface snalyais of sand tracer distributions on a carbonate beach, Bimin1, B.w.I.; Jour, Geol., v. 76, pp.1-9.

BOWEN, A.J, and IWHAN, D.L., 1966, Budget of I1ttoral sands la the vicindty of Polat Ax elello, California: U.S. Aray Corpe of Engineers Tech. Mew. $19,41 \mathrm{p}$.

BRtUU, P., and PURPURA, J., 1964, Quantitative wesearch on Ifteral drift In fleld and laboratory: Proceedings of the Nivth Cong. Coastal Enge., Lisbon, Portugal, 18, Pp. 267-283.

BavUN, P, 1965, quantitative tracings of Litcoral drift: U.S. Dept. of Agriculture Misc. Pub. 970, pp. 756-768.

CALDWELL, J.M., 1956, Wave action and sand movement near Anahelm Hay, Callfornia: U.S. Array Beach Erosion Board Tech. Mex. 68, 21 p.

CRICKWORE, M.J., and LEAH, G.H., 1962a, The measurement of sand transport by

A, v. 266 , pp. $402-421$.

CRICKAORE, M.J., and LEAN, G.H., 1962b, The meagurenent of sand transport by the thae-integration method wth radloactive tracer: Proc. Roy. Soc. (London) B, v. 270, pp. 27-47.

Doon, J.L., 1953, Stochastic processes: John w1ley sons, Inc., 387 p.

EINSTEIN, H.A., 1948, Movement of beach sand by water waves: Trans. Am, Geophys. Union, v. 29, pp. 653-655.

FAIRCHILD, J.C., 1966, Correlation of 11ttoral eransport with wave energy along shores of Vew York and New Jersey: U.S. Aray Corpe of Eng ineers Tach. Ken. 7, $102 \mathrm{p}$.

GLOSSARY OF MTEOROLOGY, 1959, Azariean Reteorological Soctety, pp. 467. 
HALTINER, G.J, and MARTIN, F.L., 1957, Dynarical and phystcal meteorology: McGraw-1111 Book Co., 470 p.

EAMADA, T., 1951, Breakers and beach eroslons: Transportation Tech. Res. Inst. (Tokyo), Rpt. No. 1, pp. 1-151.

HARRISON, W. and KRUMBEIN, W.C., 1964, Interaction of the beach-oceanatwosphere syste at VIrginia Beach, Virgluia: V.S. Army Corps of EngIneers Tech. Kea. 7, 102 p.

HARRISOW, H., and MORALES-ALAWO, R., 1964, Dynamic properties of Lmarsed gand at Virginia Beach, VIrginla: U.S. Arany Corps of Engineers, Tach. Mesa. 9, $52 \mathrm{p}$.

HARRTSON, W., and WAGNEK, K.A., 1964, Beach change at Virginta Beach, Vixginia: U.S. Axmy Corps of Enginaers siac. Paper 6, $25 \mathrm{p}$.

HARRISON, W., KRUMBEIN, W.C., and WILSON, W.., 1964, Sed LentatLon at an inlet entrance, Rudee Inlet, Virglnia Beach, Virglnia: v.S. Army Corps of Englaerg Tech. Wem. 8, $42 p$.

HARRISON, W., PORE, N.A., and TUCK, D.R., JK., 1964, Predictor equations for beach procesas and responses: Joux. Seophys. Res., 70 , pp. 6103-6109.

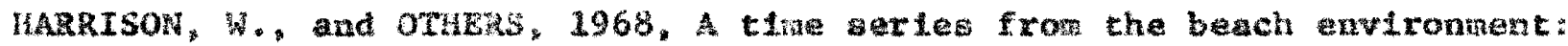
ESSA kes. Lah. Tech. Meat. (In preas).

HJULSTRÖN, F., 1935, StudLes of the morphological activity of rivers as 111ustrated by River Fyrla: guil. Geo1. Inat. Unty. Uppsala, v. 25, pp. 221-527.

IMGLE, J.C., JR, 1966, The movement of beach saad: ElsevierPub. Co., $221 p$.

TWAN, D.L., 1949, Sedtreat gorting in the l1ght of flutd wechantes: Jour. Sediment, petrol., v. 19, pp. 51-70.

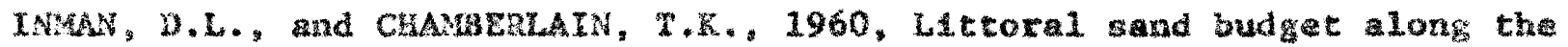
southern Californda coast: Intern. Geol. Congr., 21st Copenhagen, Abatr., pp. 245-246.

IMNAN, D.L., 1966, Mechanics of sedimentation. In: Scrtppa Inetitution of Oceanography Progress Report, sio faf. 66-5, pp. 62-66.

TWOSE, S., and SHrRAISUI, N., 1956, The neasurement of 11teoral drift by radlolsotopes: Dock harbour Author1ty, v. 36, pp. 284-233.

IPPEA, A.T., and EAGLESON, P.S., 1955, A study of sediment borting by waves shoallns on a plane beack: U.5. Arary Corps of Englneers Tech. Mem. 63, $83 \mathrm{p}$.

JAMES, W.R., 1966a, The Fourler series sodel in at analysts: office Mav. Res. Geog. 3r. Tech. Rpt. 1, 37 p. 
JAHE, W., $1966 \mathrm{~b}$, Tortran IV progran using doubla fourier series for gurface fitting of Irregularly spaced data: state Geol. Surv., Untv. of Kansas, Computer Contrtb. $5.19 \mathrm{p}$.

JOHNSON, J.K., 1956, Dynanice of nearshore sediment movement: Bu11, An. Assoc. Petro1. Geolog1sts, v. 40, pp. 2211-2232.

KIDSON, C., CARR, A.P., and suTh, D. radioactive materials to detect the movement of shingle over the seabed and alongahore: Ceograph. Jour., v. 124, pp. 210-213.

RING, C.A.K., 1959, Beaches and coasta: Edward Arnold, Ltd., 403 p.

RRUMEIN, W.C., and GRAYBILL, F.A., 1965, An Introduction to atatictical models in geology: McGrat-H111 Book, Co., 475 p.

KRUMEIN, W.C., 1966, A comparison of polynonial and Pourier models in map analysis: office rivav. Res. Geog. Sr. Tech. Rpt. 2, 45 p.

KRUMBEIN, W.C. 1967, Portran IV computer prograns for Narkov chaln expertments in geology: State Geol. Surv." Unty. of Kansas, Computer Contrib. $13,38 \mathrm{p}$.

LEOPOLU, L.B., and LANGBEI, $w .1,1962$, The concept of entropy in landscape evolution: U.s. Ceol. Surv. Brof. Paper 500-A, 20 p.

MEDVEDEv, V.C., and AIBULATOV, $. A ., 1956$, The use of tariced eand for the atudy of the transport of axlae detritus: IFv, Mikad. Navl. S.S.S.R., Ser. Georraphy., V. 4, pp. 99-102.

MLLER, B.L., 1956, 1. The relation of sediment slese parmeterg to currentw wave aystens and physlography: Joux. Geol. v. 64, pp. 425-446.

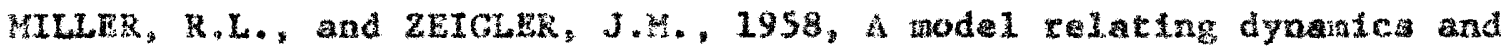
sediment pattern in aquilibrium in the recion of shoaling rowes, breaker zone, and foreshore: Jour. Ceol., Y. 66, pp. 417-441.

MLLER, R.L., and ZEICLER, J.3., 1964, A study of edineat distribution In the zone of ahoaling waves over complicated bottom topography. In: R.L. Miller (Editor), Papers in aarlne geology; Shepard comamorative volume. Macklllan $300 \mathrm{~K}$ Co., pp. 135-153.

MURRAY, 5.2., 1967, Control of grain dispersion by particle alze and wave state: Jour. Geol., v. 75, pp. 612-634.

ROBERTS, 0.7.T., 1923, The theoretcal scatterlag of swoke in tarbulent atrosphere: Proc. Roy. Soc. (Loudon) A, v. 104, pp. 640-654.

RUSSELL, R.C.B., 1960, The use of fluorescent tracers for the mearurenent of 11ttoral drift: Procedinge of the Seventh Conf. Coatal Eng., The Hague, Netherlands, $1, \mathrm{pp} .418-444$.

3AVILLE, T., JR., 1950, Jodel tud Les of sand transport along an fnfinftely straight beach: Trans. Am. Gaoplyys. UnLon, v, 31, pp. 555-565. 
SCKEIDECGER, A, F, 1958, The randoramalk model with autocorrelation of flow through porous madia: Candian Jour. Phys1cs, v, 36, pp. 649-658.

SCALIDEGCEk, A.5., 1964, 3tatisteal hydrohynames in porous media: Advancea in Hyroacience, v. 1, pp. 161-181.

SCIIELDEGER, A.R. and LAKCEEN, W.B., 1966, Probab111ty concept in geomorphology: Geol. Surv. Prof. Paper 500c, 14 p.

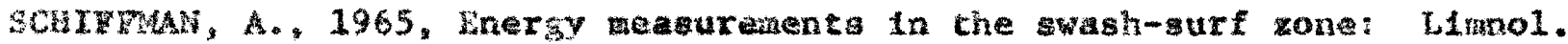
Ocanog., v. 10, p. 255-260.

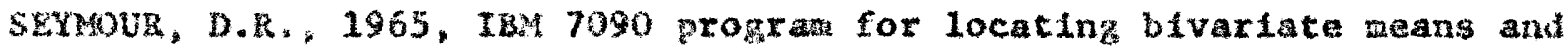
nedians: Office hav. thes. Geos. Bx. Tech. Bpt. 16, 12,p.

SHEPARD, F.P., and TWMA, D.L., 1950, Vearshore chreulation: Proceding of Hirst Con . Coastal Eng., Long Beach, Calff, 5, pp. 50-59.

SLERARD, Y.P., 1963, Subuaxine geology, 2 ed.: Harper and Row; Publishers, 557 .

SIEBOLA, E., 1963, Geolog Lat Laveselgation of nearwhore sand transport. In: M. Sear (Editor), Progress In Oceanography, Pergamon Press, 1. pp. $3-70$.

SHEDECOR, G.w., 1956, statiztcal thoda: Towa state Uaiv. Press, pp. 1-523.

WhITYE, geologlcal models wheh involv areally-distributed data: office Wav. Res. Geag. Br. Tech. Rpt. 2, 56 p.

WHGLL, R.L., 1964, Oceanographical engtuearing: Prentice-kia11, Inc., 532 p.

Wriche, F.F., 1962, The development and application of a fluorescent aricing technique for tractng sand movenenta on beaches: office Nav. Res. Geog. Br. Tech. Rp. 2, 19 p.

FAsSO, W.E., 1962, Pluorescent contings on coarse sediaents, an integrated systan: Offlce Nav, kes. Geop. Br. Rech. Rpt. 1, 48 p.

ZASSO, W.F. 1965, Rluorescent tracer particle determination of the savelocity relation for foreshore sediment transport, Sandy llook, New Jersey: Jour. Sed. Pet., v. 35, pp. 989-993.

ZETGLER, J.M., and GILL,., 1959 , Tables and graphs for the settling velocity of guartz in water, above the range of Stokes' Law: Woods Hole Oceanog. Instit. Ref. 59-36, 13 p.

ZEIOLBR, J.K., HAYES, C.R., and TUTRLE, S.D., 1959, Beach changes durIng

storm on outer Cape Cod, Massachusett: Jour. Deol.s. v. 67, pp. $318-336$. 
Johx Daniel Boon, III

Born In Austin, Texas, January 29, 1940. Graduated from Arlington H.1gh School, Arlington, Texas, Jume 1958, Klce University, Houston, Texas, June 1962 (B.A., Geology). Attended Untversity of Washington, 1962-1963, as graduate student in oceanography, anrolled February 1966, as a graduate student and candidate for the M.A. degree in warine science at the Virginia Institute of Marine Science through the College of William and Mary.

In December 1963, the author was complsaloned as an officer in the Unitad States Coast and Ceodetic Survey. After serving at sea for two years, he was asned in 1965 to the Land and Sea Interaction Laboratory (LASTL) of the Environental Science Services Adainistration in torfolk, Virginia. While a newber of the LASIL ataf, Mr. Boon publiahed a paper ent1tled: Trend Surface Analysis of Sand Tracer Distributions on Carbonate Beach, Biminl, B.H.I. 